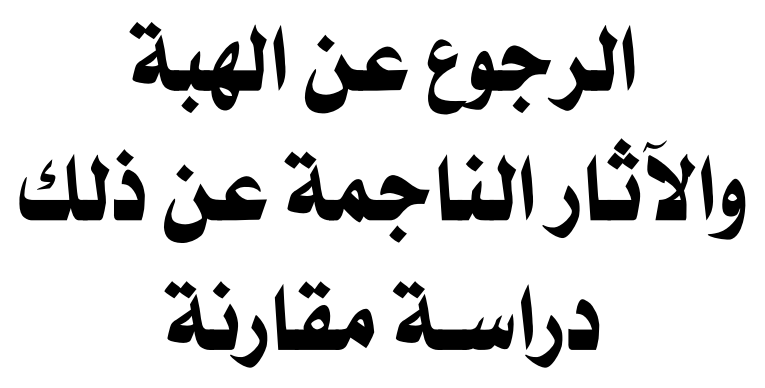

Revocation Of Donation And It's

Resulting Effects

A comparative study

\author{
د/ عبدالمنعم احمد خلينة \\ استاذ القاذوز الملدى المساعد \\ كليات بريلة الأهلية - المملكة العربية السعودية المتية المية
}




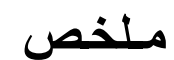

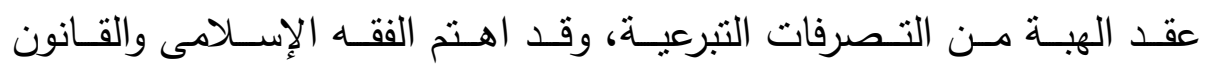

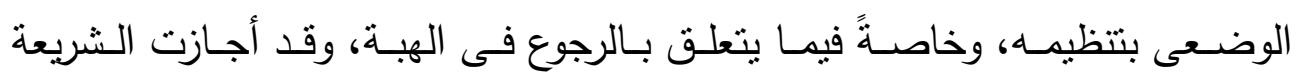
والقـانون الرجـوع فـى الهبــة، وإن اختلفــت فـى نطــاق وحـالات الرجـوع، والـسند الشرعى والقانونى للرجوع، وكذلك الآثار التى تترتب على الرجوع.

وقـد تطـرق البحـث لمفهوم الهبـة، ثم تعـرض لماهيـة الرجـوع فـى الهبـة، ثم تــاول الطبيعـة القانونيـة للرجـوع فى الهبـة، ثم بـين البحـث حكم الرجـوع فـى عقد

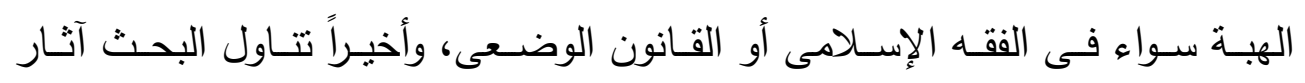

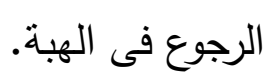




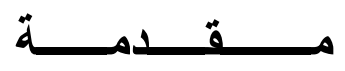

الحمــد لله رب العـالمين، والــصلاة والـسـام علـى ســبدنا محمــد الـصادق

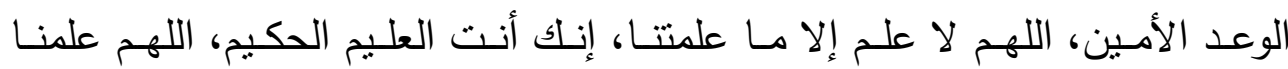

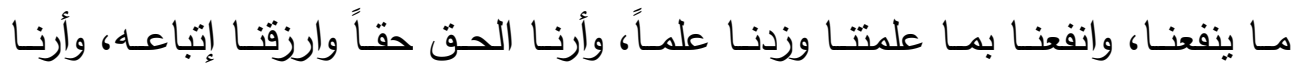

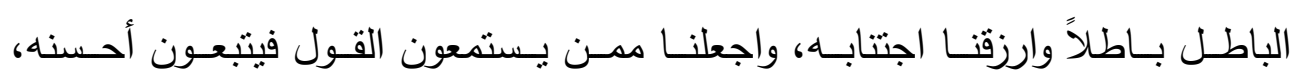
وأدخلنا برحمنك فى عبادك الصالحين.

الهبـة مـن عقـود التبـرع التـى أجازتهـا الـشريعة الإسـلامية، وشـجعت عليهـا،

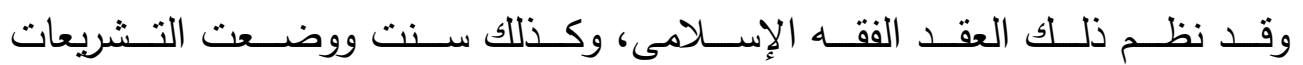
الوضـعية المقارنـة القواعد التى تتظمـه وتحكمـه، والهبـة مـن أثـرف الـصفات لمـا فيهـا مـن اسـتعمال الكـرم مـن قبـلـ الواهـب، وإزالــة الـشح عـن الـنفس، وإدخــال السرور فى قلب الموهوب له، وزرع المحبة بينهما.

والهبـة سـبب مـن أسـباب نقل الملكيـة مـن ذمـةِ إلـى أخـرى، فهى تقـع على

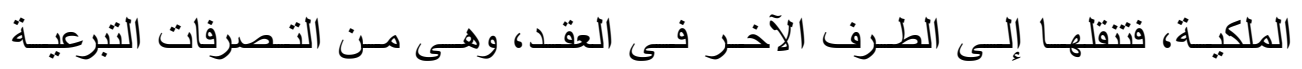

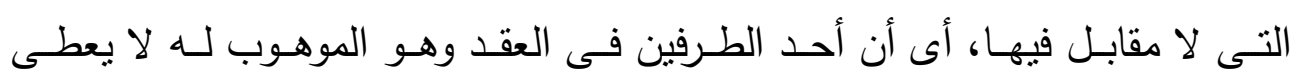
شيئًا مقابل ما يأخذه من الموهوب.

وبمـا أن الهبـة نـوع مـن العقـود التبرعيـة بـدون عـوض فـى أصــله ولكـن

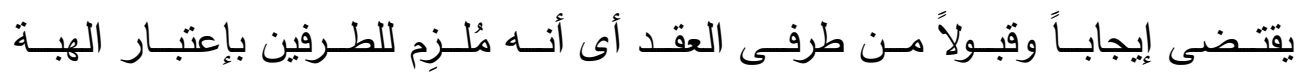
تصرف قـانونى، ويحساول هـا البحـث الإجابـة على التساؤل هـل يجـوز الرجـوع فى الهبة، وبحاول هذا البحث الإجابة على ذلك التساؤل. 


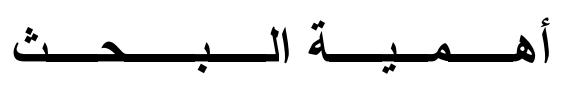

لقد أعلـت الـشريعة الإسـلامية مـن شـأن نظـام التبـرع، وأولته العنايـة إرشـاداً وترغيبـاً، وتتظيمـاً وتشريعاً، ولا أدل على ذلـك مـن النـصوص التشريعية العديـدة

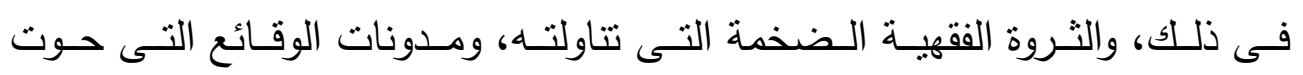

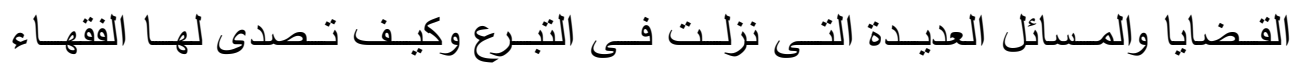
والقضاة والمحكمون، فكان لابد من الإستفادة من كل ذلك ا.

هذا وتتبع أهمية البحث من أن الهبة تتصرف إلى إنثاء حقوق جديدة لصالح

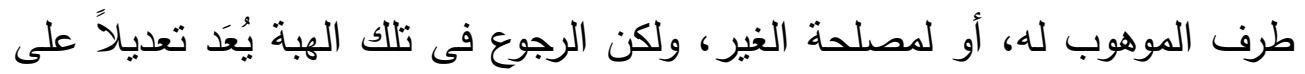
مراكز قانونية تكونت صحيحة، مما قد يضر ويؤثز على الموهوب له أو الغير.

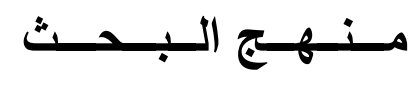

لقد كان منهجى فى هذا البحث على النحو التالى:

ا- القيام بتعريف المصطلحات الواردة فى البحث، سواء فى اللغة أو الإصطلاح الثرعى أو القانون والفقه والقضاء المقارن.

ץ- تأصيل أجزاء البحث، وعرض كل الاراء سواء فى الفقه الإسلامى أو الفقه الوضعى. r- مناقشـة للأدلة لكل جزئية والرد على النقاط. ع - يتم استخدام المنهج التحليلى الإستقرائى المقارن.

ا سماحى خاللد، النظريـة العامـة لعقود التبرعـات - دراسـة مقارنـة، رسـالة دكتوراة، قسم القانون

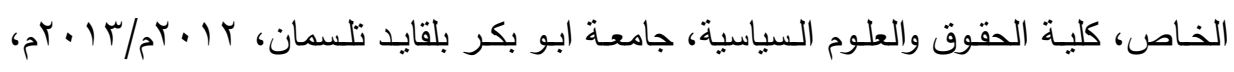




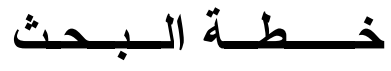

سـوف نقسم هذا البحث إلى عدة مباحث، حيث سوف نخصص المبحث الأول

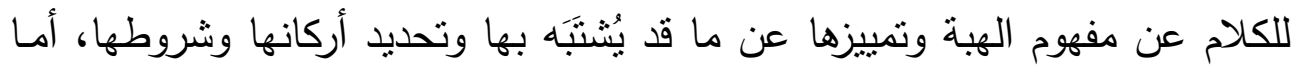

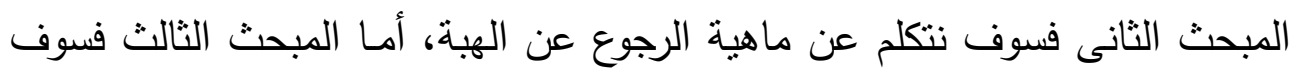

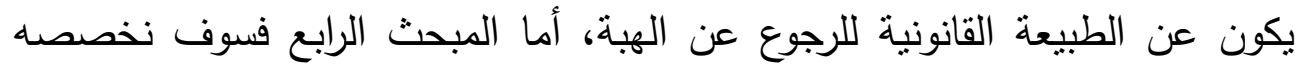

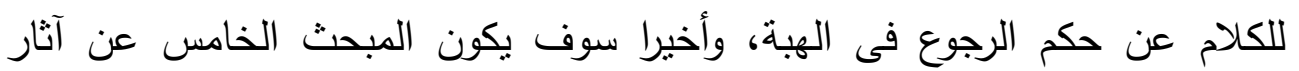
الرجوع عن الهبة.

$$
\text { المبحث الأول: مفهوم الهبة }
$$

المبحث الثانى: ماهية الرجوع فى الهبة

المبحث الثالث: الطبيعة القانونية للرجوع فى الهبة

المبحث الرابع: حكم الرجوع فى عقد الهبة

المبحث الخامس: آثار الرجوع فى الهبة 


\section{الــــــــــــ الأول}

\section{مسفــهـوم الـهـبـة}

\section{تمهيد وتقسيم:}

سوف نقسم هذا المبحث إلى عدة مطالب، حيث سيكون المطلب الأول عن تعريف الهبة فى اللغة، في حين سيكون المطلب الثانى عن تعريفها فى الإصطلاح والقانون.

\section{المطلب الأول}

\section{تـــــريــف الــهبــة فى اللغة}

وتُطلَق الهبة فى اللغة(') على العطية الخالية من العواض والأغراض فإذا كثرت

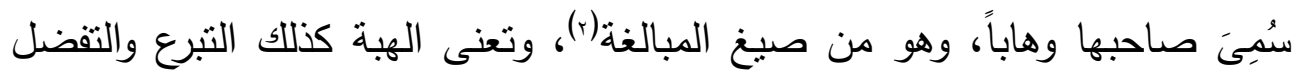

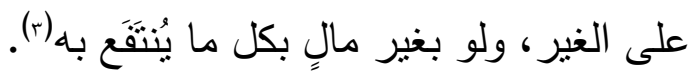
وقد قال الله عز وجل " ووهبنا له اسحاق ويعقوب"(؛)، وقال عز وجل " يهب لمن يشاء اناثاً ويهب لمن يشاء الذكور"(ه)، ومن أمنلة هبة المال هبة شخص للآخر

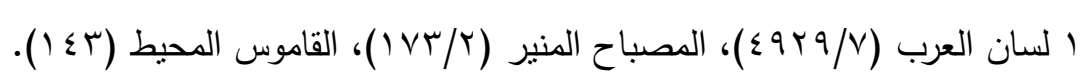

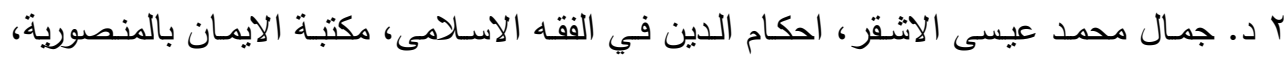

$$
\text { rar }
$$

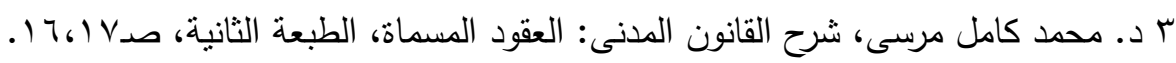

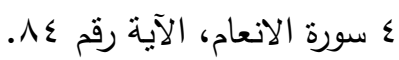

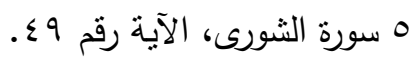


سيارة أو دار، أما هبة غير المال كقول إنسان لآخر يهب الله للك ولداً()، لقوله تعالى "فهب لى من لدنك ولياً"(r).

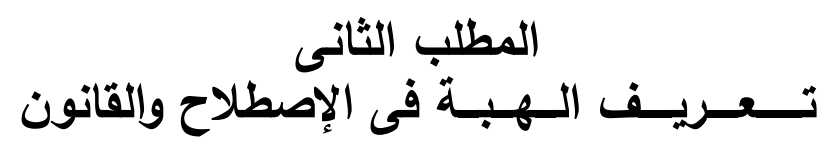

عرفها الحنفية بأنها " تمليك العين بلا عوض بّ"؛، فى حين عرفها المالكية بأنها

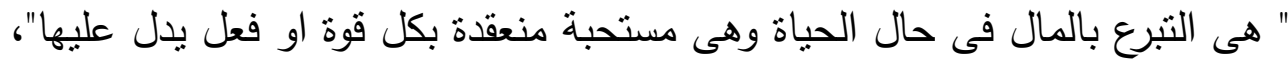

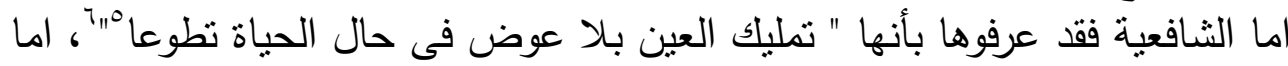

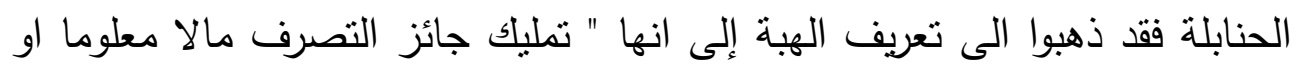

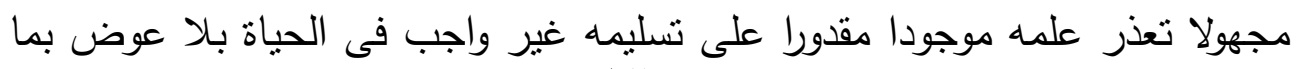

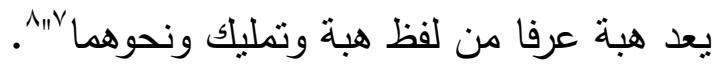

ا د. محمد تقنية، الهبة فى قانون الاسرة والقانون المقارن، رسالة دكتوراة، معهد الحقوق والعلوم

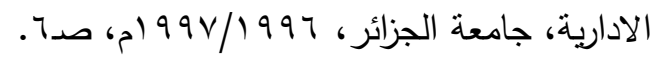

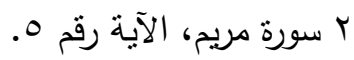
r ومعنى ذلك أن الثخص الذهى يملك عينا ملكا صحيحا يجوز لله ان يهب لغيره من دون ان ياخذ منه عوضا فى الحال او المستقبل وذللك اثثاء حياته.

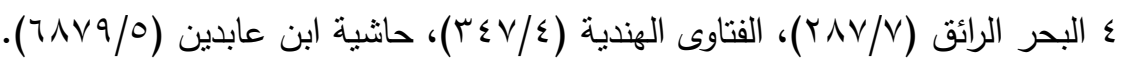

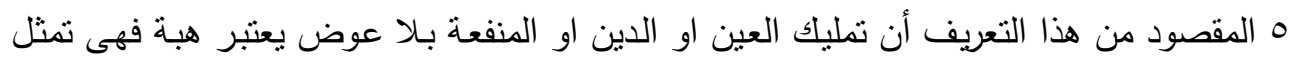

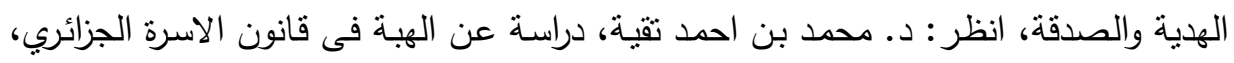

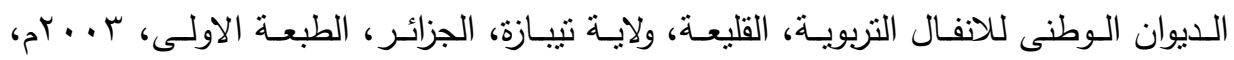
صع 1.

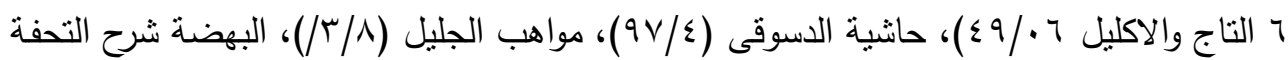

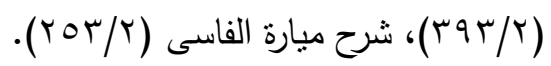

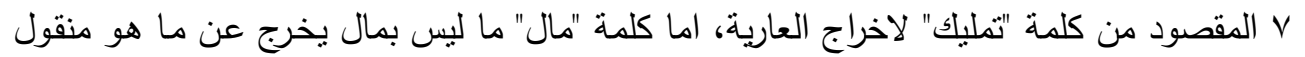

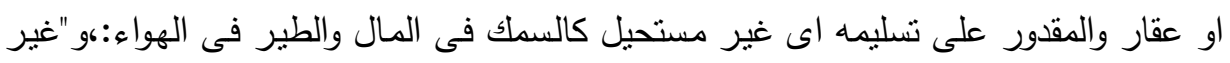

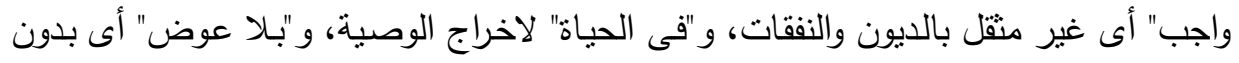

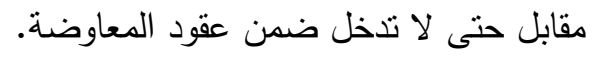

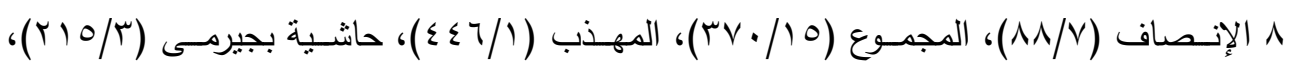

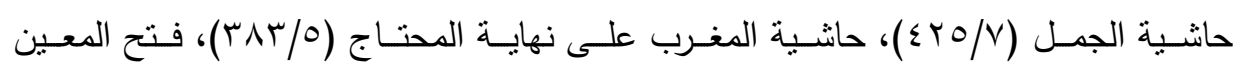

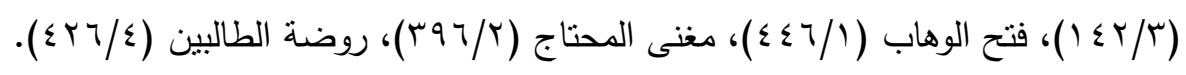


إذن فإننا نذهب مع البعض إلى أن الهبة هى عقد تمليك بملك فيه الواهب فى له

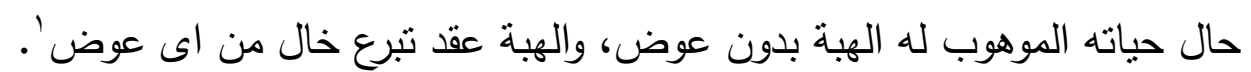
وقد عرف القانون الروماني الهبة لما بعد الموت ( mortis causa ) ) donation

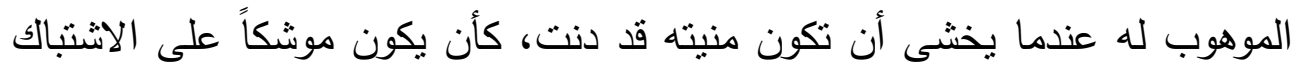

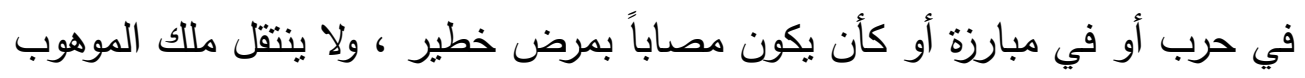

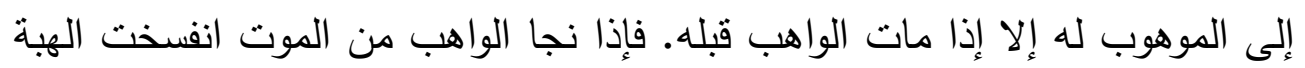
من تلقاء نفسها'r.

أما القانون المدنى العراقى فقد عرف الهبة فى المادة رقم 1/4 المنه بقوله

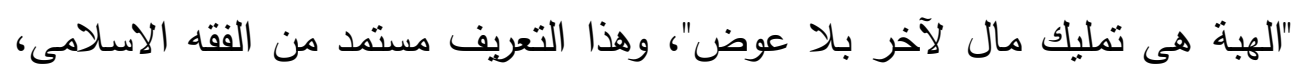

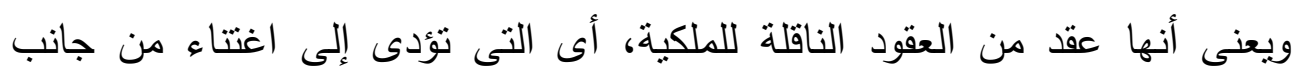

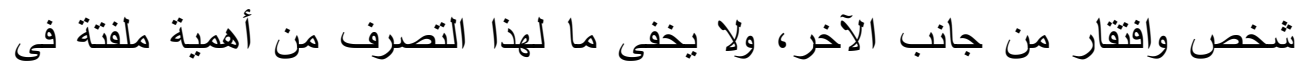

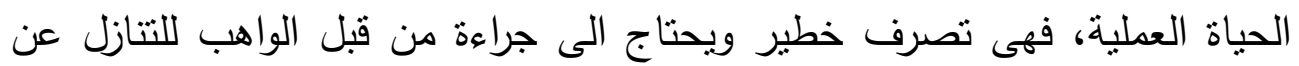
امواله أو جزء منها، وقد يكون ذا تأثير كبير على وضعيته المالية بما قد يلحق ضررا بورثثه كحرمانهم من حقهم فى الميراث.

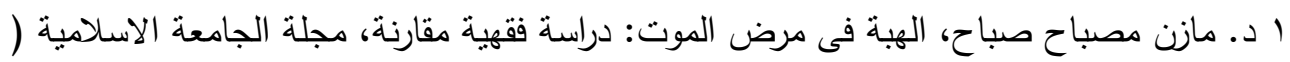

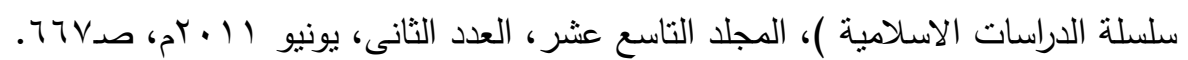

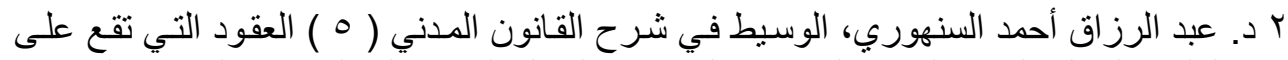
الملكية المجلد الثاني الهبة و الثركة والقرض والثر الدخل الدائم والصلح، دار النهضية العربية،

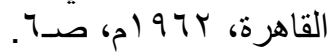

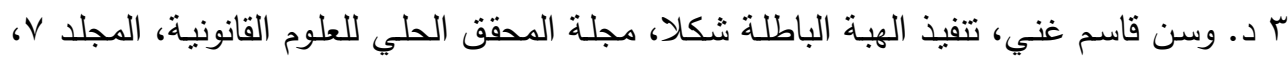

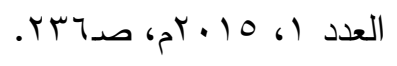


أما القانون المدنى المصرى فقد عرف الهبة فى المادة رقم الهبة عقد يتصرف بمقتضاه الواهب فى مال لله دون عوض. r- ويجوز للواهب،

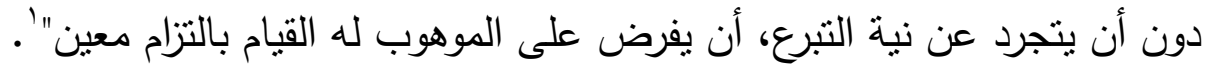
وتوضيحها بما جاء في مذكرة المشروع التمهيدي كما يلي:

يُعرِف المشروع الهبة تعريفاً يميزها عن غيرها من أعمال التبرعات، فهي تشترك

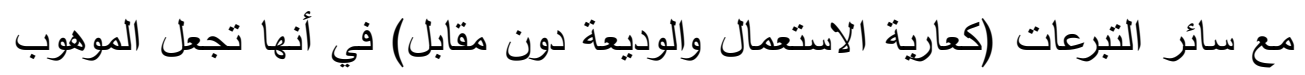
له يثري دون عوض، وفي أنها تقترن بنية التبرع ولكنها تنفرد بخاصية هي أنها من أعمال التصرف، فالواهب يلزم بنقل ملكية دون مقابل، وينزتب على ذلك أن الالتزام

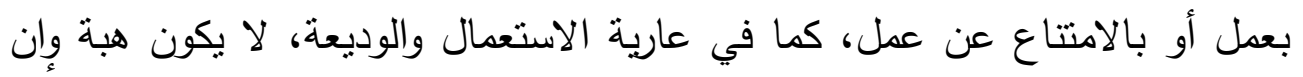

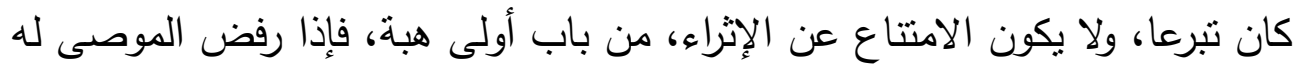

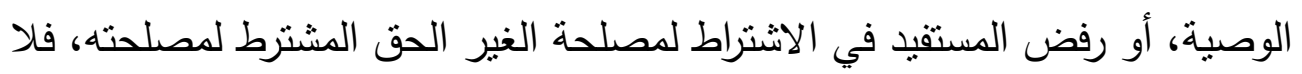

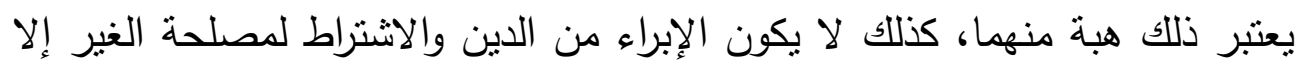
هبة غير مباشرة، لأنها لا تشتمل على التزام بنقل ملكية. أما القانون المدنى الفرنسى فقد عرف الهبة فى المادة رقم ع9 بأنها : " هى تصرف يتخلى به الواهب حالاً وبصورةٍ لا تقبل الرجوع عن الموهوب لصالح الموهوب له الذى قبلها". La donation entre-vifs est un acte par lequel le donateur se dépouille actuellement et irrévocablement de la chose donnée, en faveur du donataire qui l'accepte. 


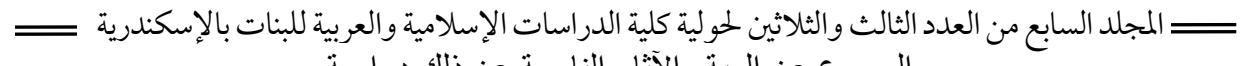

$$
\begin{aligned}
& \text { الرجوع عن الهبة والآثار الناجمة عن ذلك دراسية الإسة } \\
& \text { أما القانون المدنى الألمانى فقد عرف الهبة فى المادة رقم } 7 \text { اه بقوله' : } \\
& \text { "الهبة هى كل تصرف من شأنه أن يعنى شخصاً آخر بأحد عناصر ثروته }
\end{aligned}
$$

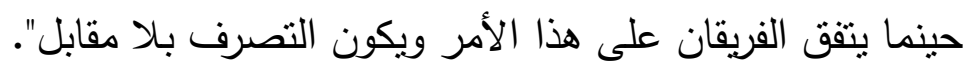

Tout acte de disposition par lequel une personne enrichit une autre au moyen d'un élément de son patrimoine est une donation quand les deux parties sont d'accord sur ce point que la disposition est effectuée a titre gratuity ${ }^{r}$.

أمسا القانون الجزائرى فقد عرف الهبة فى المادة Y ·. بأنها " الهبة تمليك بلا

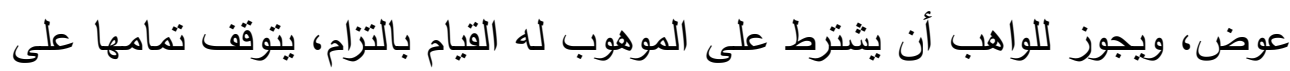

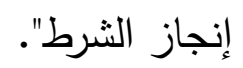

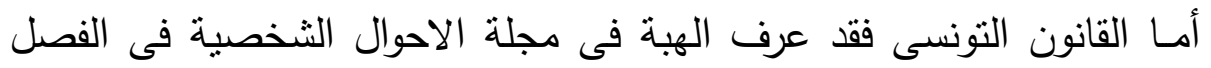

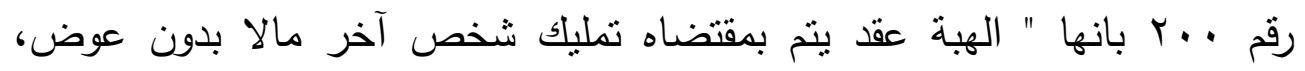

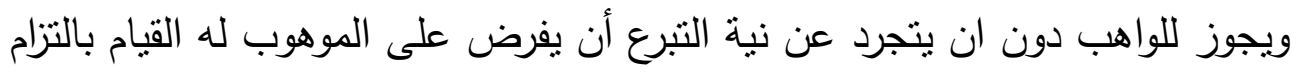

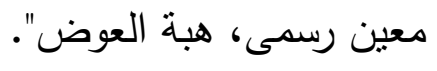

1 https://www.gesetze-im-internet.de

r) Section 014 Concept of donation: 1) A disposition by means of which someone enriches another person from his own assets is a donation if both parties are in agreement that the disposition occurs gratuitously.

$(\checkmark)$ If the disposition occurs without the intention of the other party, the donor may, specifying a reasonable period of time, request him to make a declaration as to acceptance. Upon expiry of the period of time, the donation is deemed to be accepted if the other party has not previously rejected it. In the case of rejection, return of what has been bestowed may be demanded under the provisions on the return of unjust enrichment. 


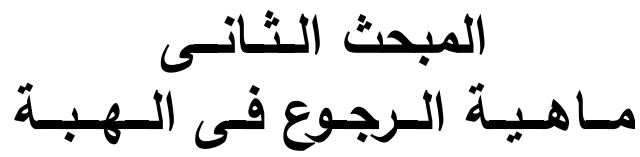

تمهيد وتقسيم:

سـوف نقسم هذا المبحث الى عدة مطالب، حيث سنخصص المطلب الاول لتحديد مفهوم الرجوع فى الهبة لغوياً، أما المطلب الثانى فسوف يكون عن مفهوم الرجوع فى الهبة اصطلاحاً، وذلك على النحو التالى.

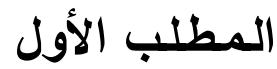

\section{تعريـف الرجوع لغنة}

الرجوع لغنةً يُقصند بـه عدة معانِ، ومنها'

1- رجع بمعنى عاد، يُقال: رجع فلان من سفره، عاد منه، ومنه رجع فى

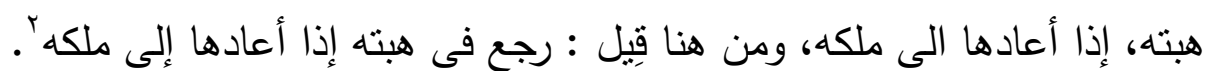

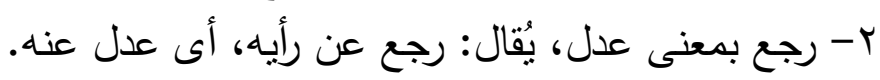
r- رجع بمعنى نرك، يُقال: رجع عن الثئ، نركه.

ا انظر : ابن منظور، أبو الفضل جمال الدين محمد بن مكرم الإفريقي المصري، ت:(1) (1)هـ).

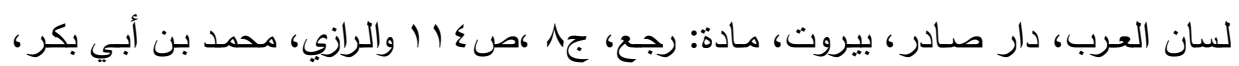
ت:(1)

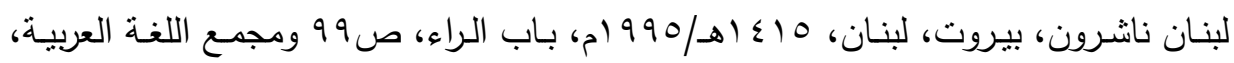

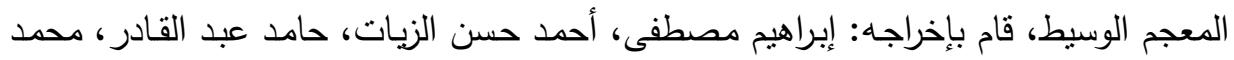

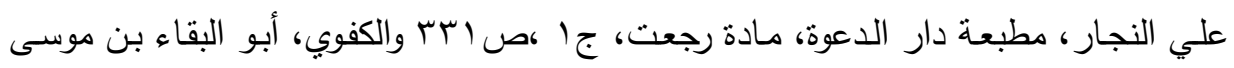

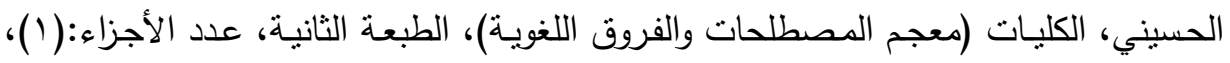

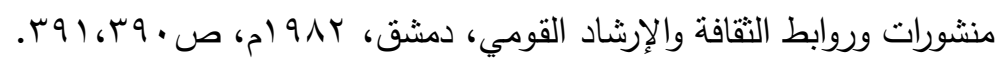
r د. نسيمة شيخ، أحكام الرجوع في التصرفات التبرعية في القانون الجزائري " الهبة - الوصية الوقف : دراسة مقارنة ددعمة بالأحكام الفقهية والاجتهاد القضائي "، الطبعة الثانية، دار هومئه

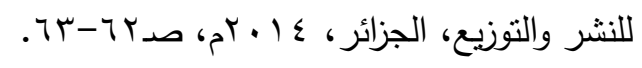


؟- رجع بمعنى ارتد وانصرف، يُقال: رجع هو، ارتذ وانصرف، جاء فى القرآن

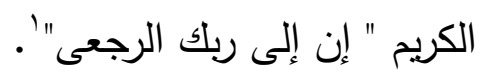

ونحن نذهب مع البعض ‘ إلى أن هذه المعانى المذكورة وإن كانت متقاربة إلى لى حدٍ كبير إلى أننا نرى أن الرجوع بمعنى الرد هو الأُقرب الى المع المعنى المراد فى هذا البحث إذ أن الراجع عن عقده يعود برجوعه هذا الى ما كانت عليه الحال قبل العقد.

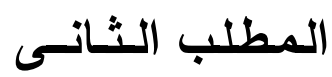 \\ تعريف الرجوع إصطلاحاً}

وردت فى تعربف الرجوع إصطلاحا أكثر من تعربف ومن تللك التعربفات، أنه

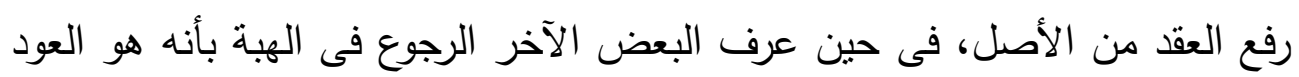

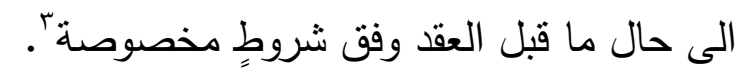
وكذلك فإن بعض الفقهاء استعملوا الفسخ كمعنى للرجوع، ومن ذللك قولهم الرجوع فسخ العقد بعد تمامهء، فى حين عرفه آخرون بأنه زوال عقد الهبة بإرادة طرفٍ واحدٍ لسبٍِ من الأسباب المحددة قانوناًْ. وقد ذهب رأى آخر إلى ان الرجوع فى الهبة هو عود الواهب فى هبته بالقول او بالفعل بغية ارتجاعها واستردادها من الموهوب له رضاء او قضاء وفق شروط معينة.

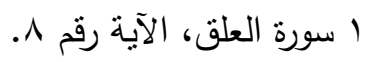

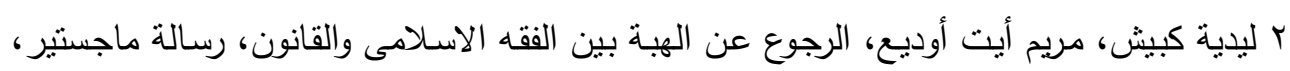

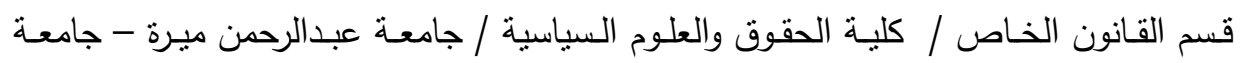

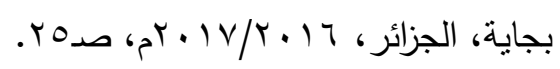

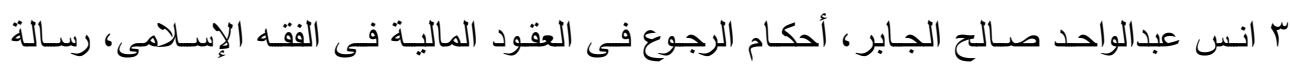

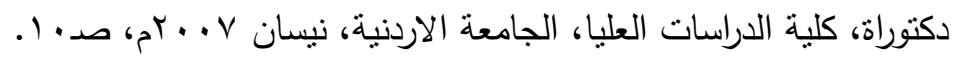

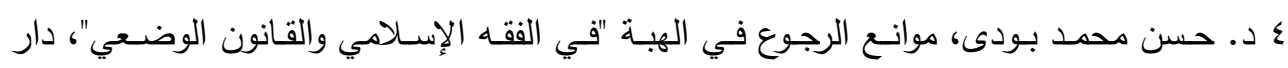

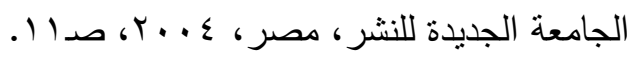
0 د. نسيمة شيخ، أحكام الرجوع في التصرفات التبرعية في القانون الجزائري " الهبة - الوصية -

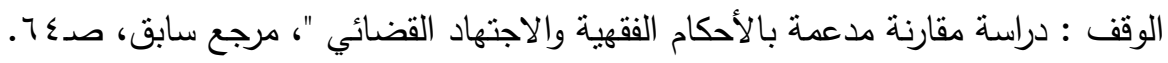


وقد وضع أحد الباحثين' تعربفا للرجوع بأنه هو " نقض العقد القابل لذلك

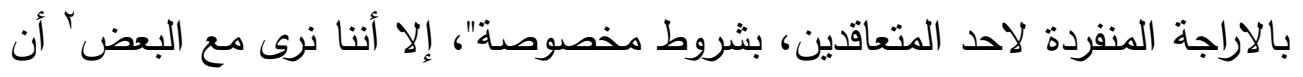
هذا التعريف غير جامع وغير ملم، إذ أنه لا يتضمن ما يتم باراتين، كما فى خيار الثرط او الاقالة، وكذللك فانه لا يشير الى الآثار التى تترتب على الرجوع.

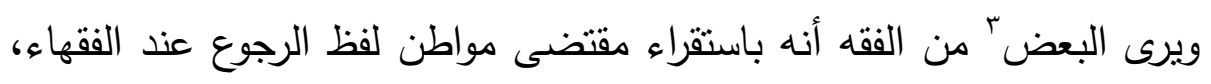
فانه يظهر ان الفقهاء احيانا يطلقون لفظ الرجوع ويقصدون به معنيً أصيلاً، وأحياناً يطلقونه ويقصدون به معنى تبعياً، وقد أوضح هذا الرأى ذلك على النحو التالى: أما قوله معناه المقصود أصالة: فهو حكم الرجوع فى العقد، والذى يعنى به: رفع حكم العقد، وإعادته إلى ما كان عليه، ومنه قوله تعالى ؛ٔ: " إنه على رجعه

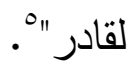

وأما قوله معانه المقصود تبعا: فهو ما يتزتب على رفع حكم العقد من أثز، ويتمنل برجوع المشترى فى الثمن، ورجوع البائع بالمبيع مثنلا. ونرى مع البعض إلى أن التعربف الأخير هو الأقرب للصحة، والدقة، والشمول، بإن ذلك أنه يشمل الرجوع بالتراضى بين الواهب والموهوب له، وكذا الرجوع بالتقاضى

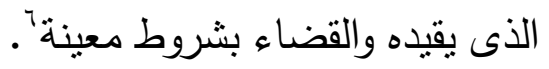

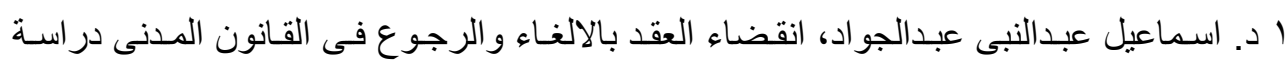

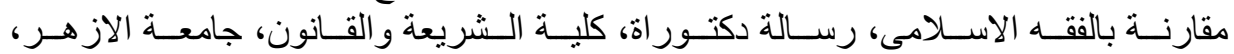
إ)

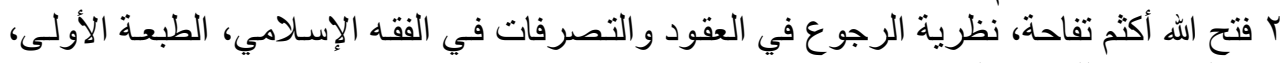

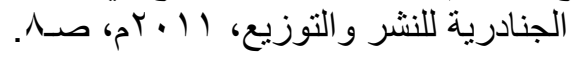
r انس عبدالواحد صالح الجابر، أحكام الرجوع فى العقود المالية فى الفقه الإسـلامى، مرجع سابق،

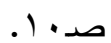

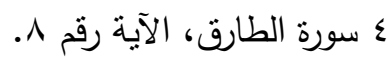
ه قال الشوكانى فى تقسير هذه الآية : " إن الله سبحانه وتعالى على رجع الانسان، أى اعادته

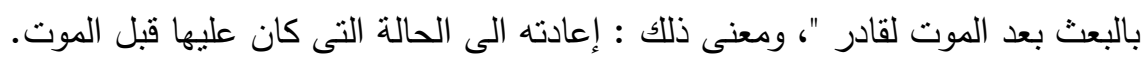

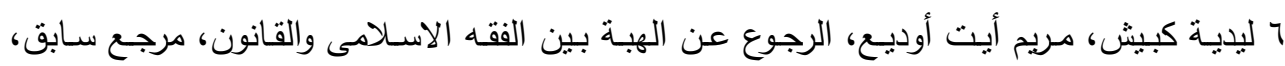




\section{المبحث الثنانـث}

\section{الطبيعة القانونية للرجوع فى الهبة}

تمهيد وتقسيم:

سوف نقسم هذا المبحث الى عدة مطالب، حيث سيكون المطلب الأول عن

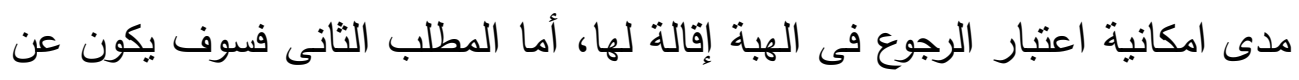

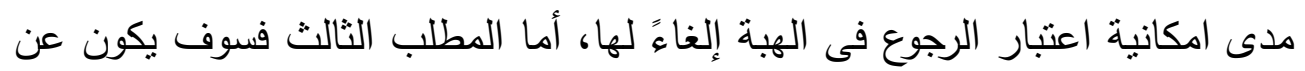

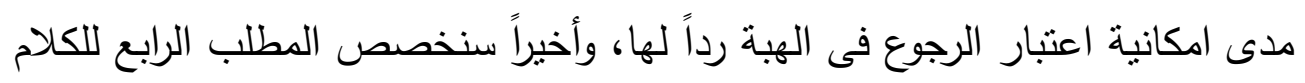
عن مدى امكانية اعتبار الرجوع فى الهبة فسخاً لها.

\section{الــــــب الأول}

\section{الرجـوع فى الـهبـة إقـالـة لـها}

الإقالة لغةً : تعنى الرفع والإزالة، ومن ذللك قولهم: أقال اله عثرته بمعنى أزالها

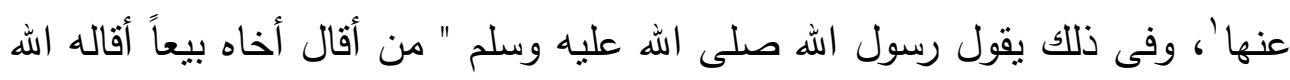
عثرته يوم القيامة "آ.

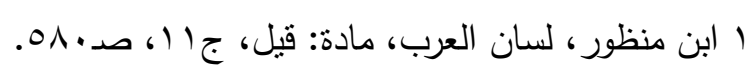

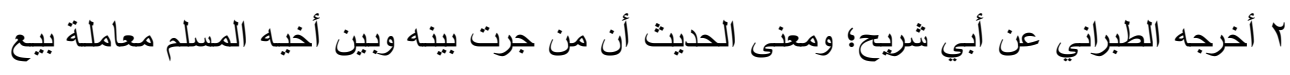

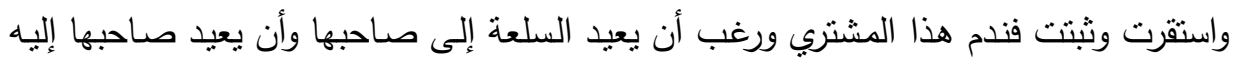

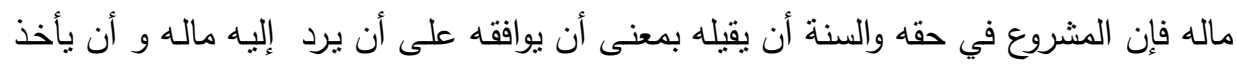

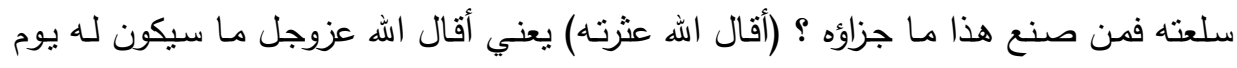

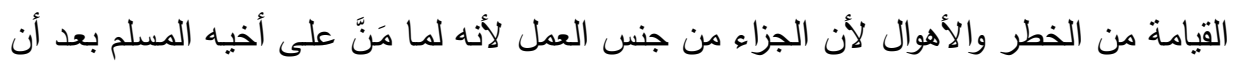

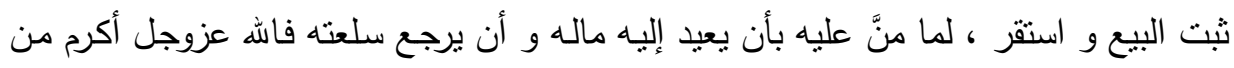
عبده فيمن عليه جل وعلا في يومٍ يحتاج إليه. 
أما اصطلاحا فالاقالة عُرفت من قبل الفقهاء بعدة تعربفات، أهمها ما ذكره ابن نجيم، حيث عرفها بالمعنى العام، والمعنى الخاص، فقال: الإقالة بالمعنى العام: رفع العقد، وأما الإقالة بالمعنى الخاص فهى: رفع عقد البيع.

وقد عرفها المالكية بأنها: " نرك المبيع لبائعه "'، أما الثافعية فقد عرفوها بأنها:

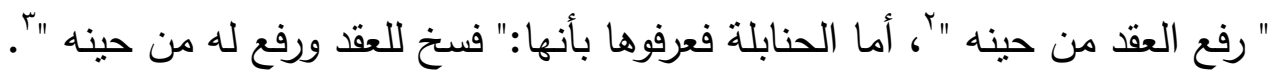
ونحن نرى مع البعض أن هناك صلة بين كلٍّ من الرجوع والإقالة، حيث أن كلاً منهما يدل على رفع حكم العقد، والعود فيه إلى ما كان عليه، ومع هذا الاتفاق بينهما من حيث المفهوم العام، إلا أن الرجوع يختلف عن الإقالة من حيث شرط ومحل كلٍٍ منهما، إذ أن من شروط صحة الإقالة رضا المتعاقدين، وفي ذلك يقول ابن نجيم: " وأما شرائط صحتها - أي الإقالة - فمنها رضا المتعاقدين؛ لأن الكلام في رفع عقد لازم، وأما رفع ما ليس بلازم فلمن له الخيار، بعلم صاحبه، لا برضاه "؛ أ.

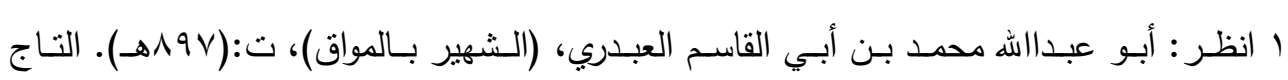

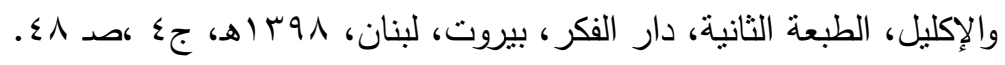

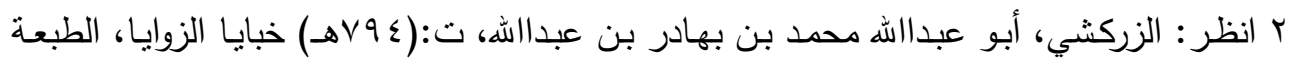

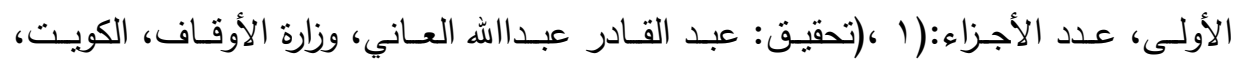

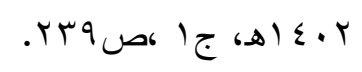

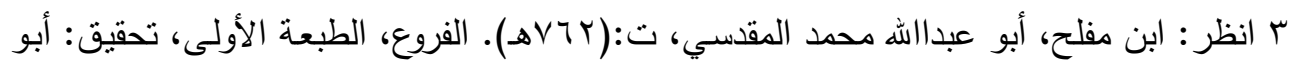

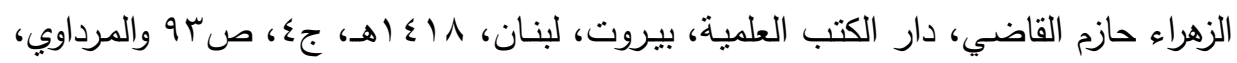

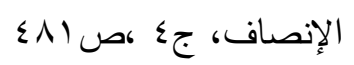

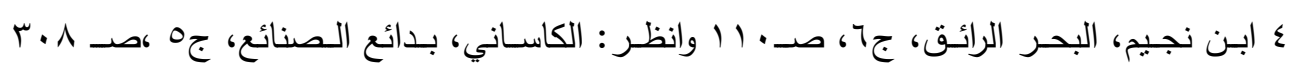

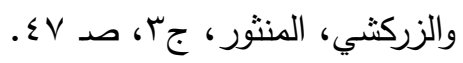




\section{الـمـطلـب الثانــى}

\section{الرجـوع فى الـهبـة إلغاء لـها}

الققه الاسلامى لا يميز بين الرجوع والالغاء، حيث يعتبرهما شيئا واحدا، فإنهاء عقد الوكالة بالإرادة المنفردة للموكل او الوكيل رجوع عنها وإنهاء عقد الهبة رجوع

غير أن فقهاء القانون الوضعى يميزون بين الالغاء والرجوع، فالالغاء هو تصرف قانونى من جانب واحد، يترتب عليه بالنسبة للمستقبل إنهاء العقد، بناء على نص القانون، وترجمة الالغاء بالفرنسية Resiliation، أما الرجوع فهو Revocation وهما معنيان مختلفان، رغم نقاط التتابه الكثيرة بينهما'، إذ أن كلا النظامين استثناء على مبدأ القوة الملزمة للعقد.، ولكن يتشابهان فى الجوانب التالية؛؟؛ - ان كل منهما يعتبر استثناءاً على مبدأ العقد شريعة المتعاقدين.

- أن سبب كل منهما لاحق على وجود العقد بحيث يفترض فيها وجود تصرف قانونى صحيح مستكمل بكل شروط الانعقاد ثم يقوم احد المتعاقدين بحل الرابطة التعاقدية دون اشتراط موافقة الطرف الآخر على ذلك.

- أن كلاً منهما حق لمن تقرر له، ومن ثم لا تترتب أية مسؤولية على ممارسته إلا إذا تعسف من تقرر لله الرجوع أو الالغاء من استعمال هذا الحق او نص القانون على خلاف ذلك.

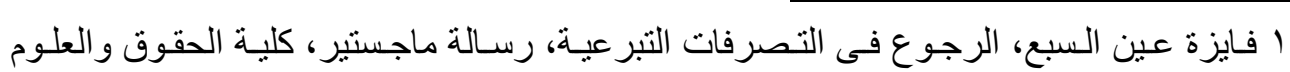

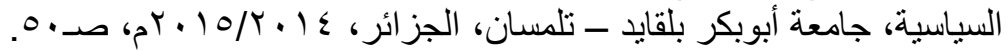

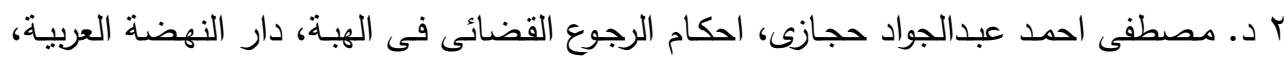

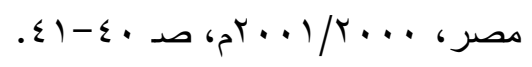


- أن الحق فى الرجوع مثل الحق فى الالغاء يعتبر حقا شخصيا ينصرف استعماله لمن تقرر له قانونا دون سواه، ولا يجوز التتازل عنه مسبقا.

وعلى الرغم من تشابه الرجوع والالغاء فى عدة نقاط إلا أن هنالك فارقا جوهريا بينهما يتمنل فى الاثر المترتب عنهما، ذلك ان الرجوع له اثز رجعى ينرتب عليه

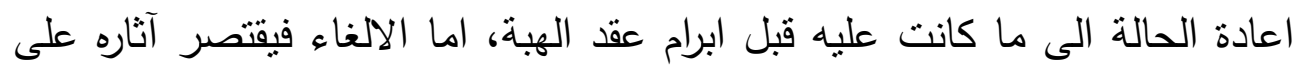
المستقبل فقط، وعليه فانه لا يمكن تكييف الرجوع على انه الغاء لعقد الهبة' .

\section{الــــــب الثالث}

\section{الرجـوع فى الهـبـة رداً لـها}

"رد" مصدر رددت الثـئ ومن معانيه منع الثئ وصرفه، ورد الثـئ أيضاً إرجاعة، ورد عليه الثئ إذا لم يقبله، والرد كذللك نوع من التسليم لانه يعيد ما كان ثابتا وقد فاتَ'، وهو جنس فى التعريف يشمل أى رد سواء كان رد العقد أم غيره وبإضافته إلى العقد خرج به ما سواه من التصرفات غير العقدية كقرارات الحكام والأمراء والإقرار بالدعوى وغيرها؟ّ.

والفقهاء أحياناً يستعملون الرد والرجوع بمعنى واحدء، ومنه قولهم: " وألفاظ الرجوع رجعت فى هبتى، أو ارتجعتها، او رددتها الى ملكى "هاء ل.

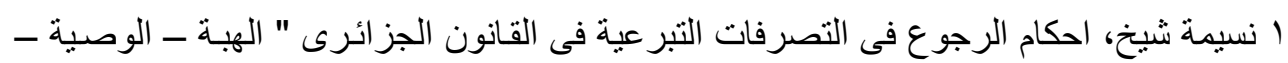

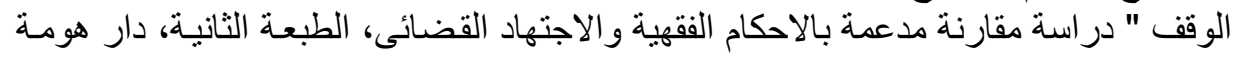

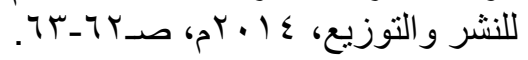

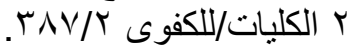

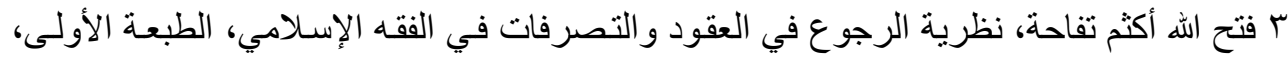

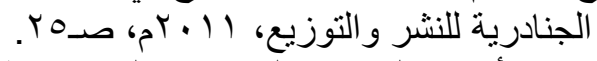

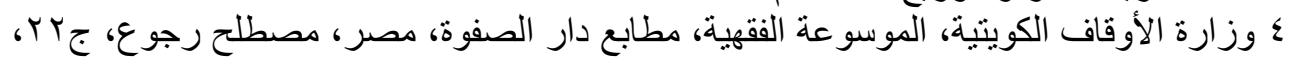

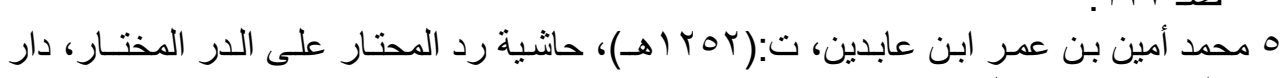

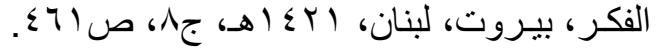


إلا أن لفظ الرجوع يختلف عن الرد من حيث كون الرجوع يختص فيمن يصدر

منه التصرف، كالرجوع فى الهبة، والوصية، فى حين يستعمل الرد فيمن صدر التصرف لصالحه، كرد المستعير للعارية، ورد الموصى له الوصية' . وعليه فان الفرق بين الرجوع والرد هو أن الرد يكون أثراً من آنار الرجوعَ، فاذا حصل الرجوع عن عقد من العقود - عقد البيع مثنل - ترتب عليه اثره، ذلك بأن يسترد البائع المبيع، ويسترد المشترى الثمن، وكذلك اذا حصل الرجوع عن عقد الهبة،

ردت الهبة الى مالكها، وهكذا. إذن فان الرد هو الاثر الثانى للرجوع بعد الفسخّـ

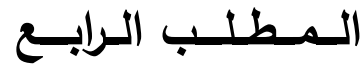

\section{الرجـوع فى الهربـة فسخاً لهـا}

الفسخ لغة : مصدر بمعنى نقض، ومنه فسخت البيع: أى نقضته، فانتقض،

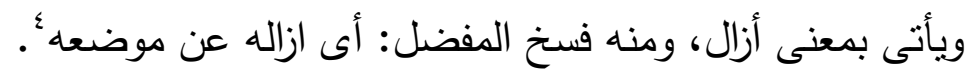
وبستعمل الفقهاء الفسخ بمعنى الرجوع أحياناً، ومن ذلك قول الزركثي:" الفسخ التخ

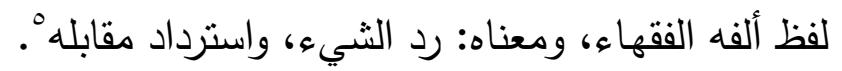
ولكن الاثر المنرتب عن الرجوع فى عقد الهبة يختلف عن الفسخ من جوانب

ا وزارة الأوقاف الكويتية، الموسوعة الفقهية، مطابع دار الصفوة، مصر، مصطلح رجوع، جr Y،

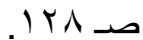
r يقول الكاسـانى " إذا انفسخ العقد بـالرجوع، عـاد الموهوب الـى قديم ملك الواهب ". انظـر:

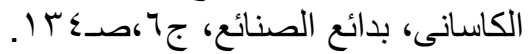
r انس عبدالو احد صالح الجابر، أحكام الرجوع فى العقود المالية فى الفقه الإسلامى، مرجع سابق، صـ 17.

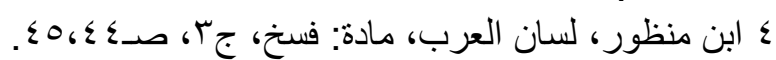

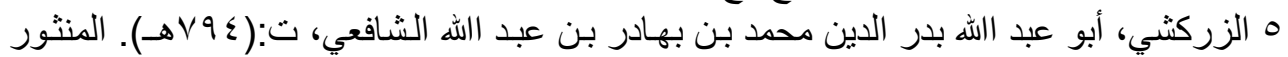

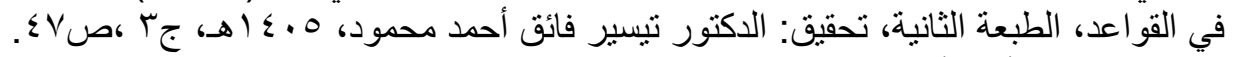

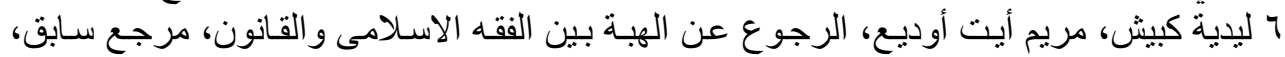

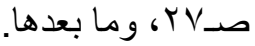


- أن الفسخ جزء أساسه خطأ المدين والمتمثل في إخلاله بالتزاماته الناشئة عن

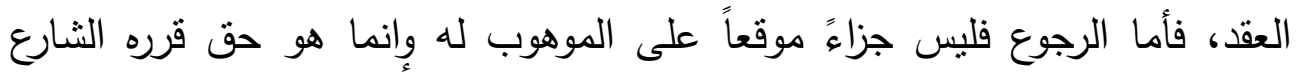

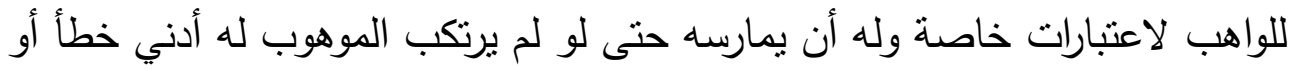

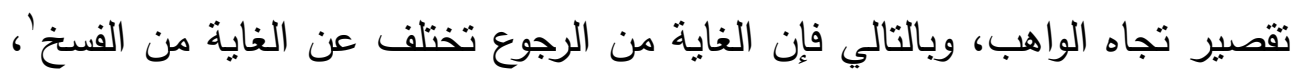

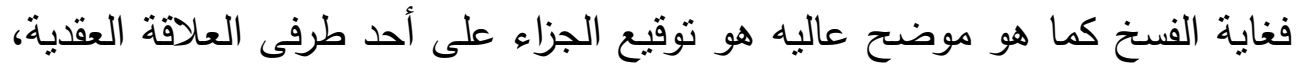
الذى أخل بالتزامه اتجاه الطرف الآخر الذى قام بكل التزماته، فلهذا الاخير ان يطالب التهاه

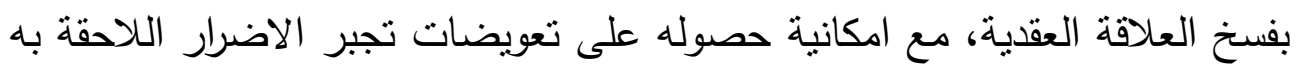

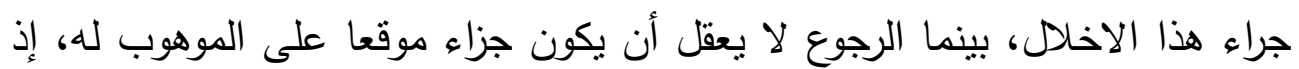

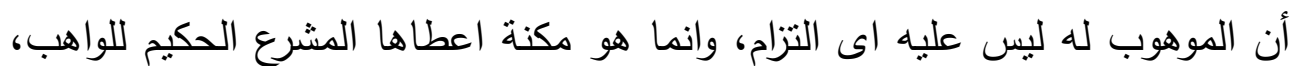

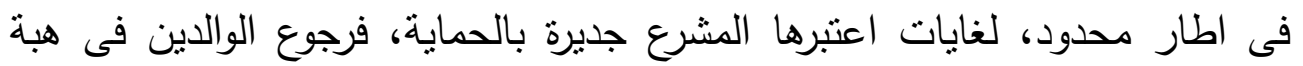
وهبها أحدهما، او كلاهما لابنهما، ليس إلا فى مصلحة هذا الابن، ومصلحة الاسرة، هذا الرجوع الذى ترك لتقدير الابوين، لكمال شفقتهما ورحمتهما ومعرفتهما بابنهما'. - أن القانون يعطي القاضي سلطة تقديرية واسعة في حالة الفسخ القضائي فله

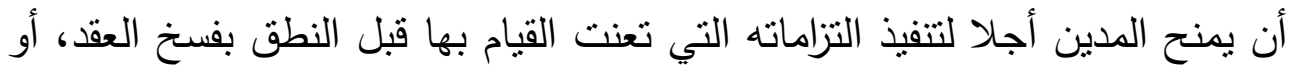

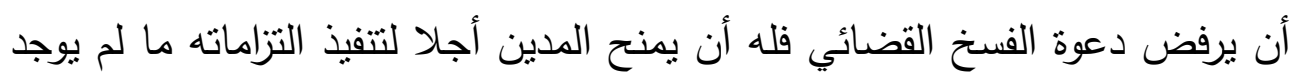

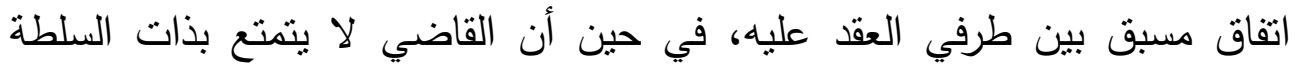

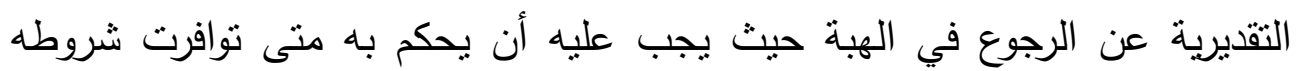
وانتقلت موانعه.

- أنه يجوز للمدين الذي لم ينفذ التزاماته التعاقدية أن بتفادى الحكم بالفسخ، بعكس الرجوع الذي لا يمكن فيه للموهوب له أن يتوقى الحكم به في الهبة. لمنئ.

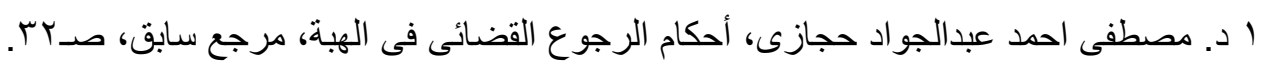

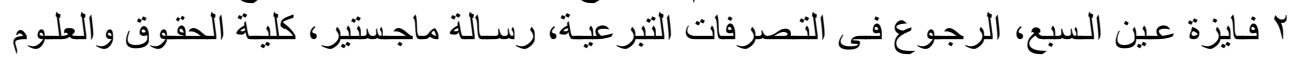

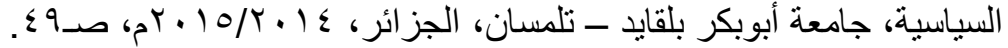


- أن حق الواهب في الرجوع يتعلق بالنظام العام فلا يجوز التتازل عنه مسبقاً

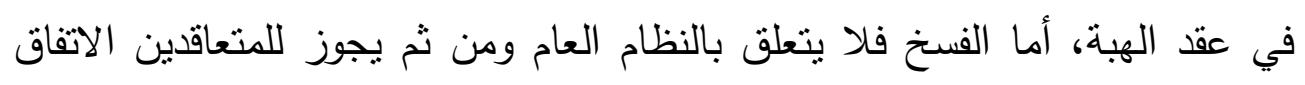
عليه مسبقا في العقد.

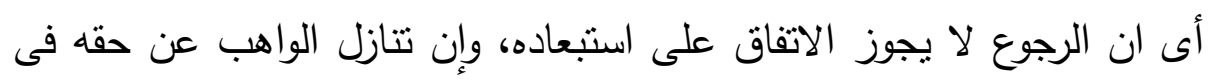

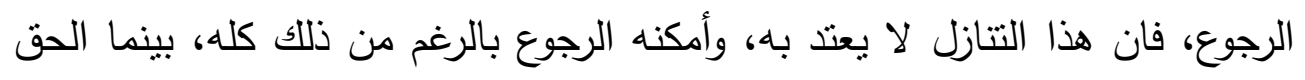

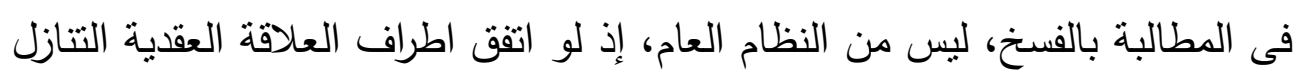

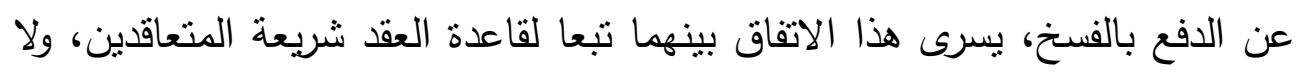

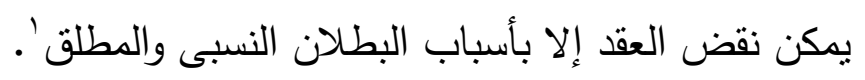

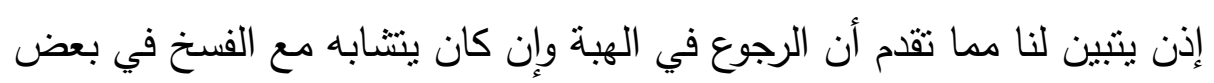

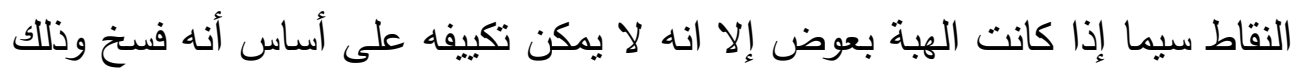
لإختلاف نظاميهما القانونيين.

هذا ولم يختلف فقهاء الثريعة الإسلامية بخصوص تكييف الرجوع إن تم بمعية القاضى، إذ اعتبروه فسخاً للهبة؛، ولكنهم اختلفوا فى الرجوع فى الهبة الذى يقع بعيداً عن القضاء.

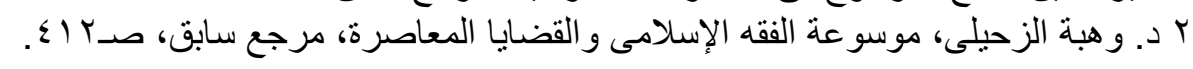




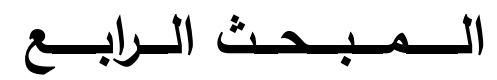

\section{حكـم الـرجـوع في الـهبة}

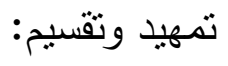

لتحديد حكم الرجوع فى الهية، فسوف نبين موقف الفقه الاسلامى فى المطلب الاول، اما المطلب الثانى فسوف يكون عن موقف التشريعات الوضعية المقارنة، وذللك على النحو التالى. المان.

\section{المطلب الأول}

\section{مشروعية الرجوع فى الهبة فى الفقه الاسلامى}

سبب الاختلاف كما يقول ابن رشد "تعارض الآثار" فمن لم بر الرجوع في الهبة

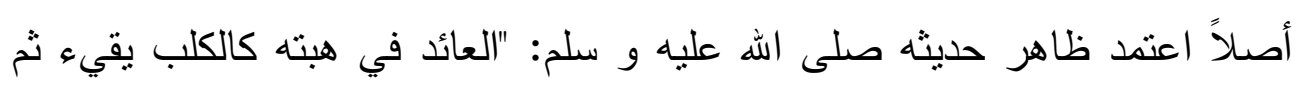

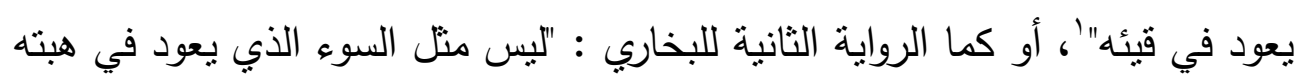

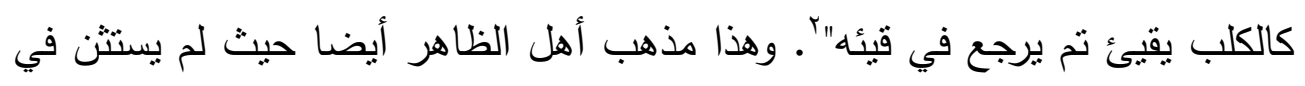

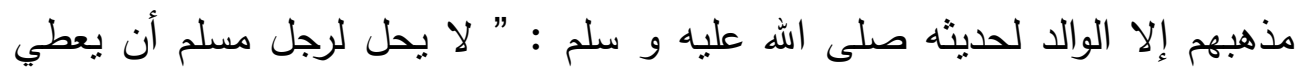

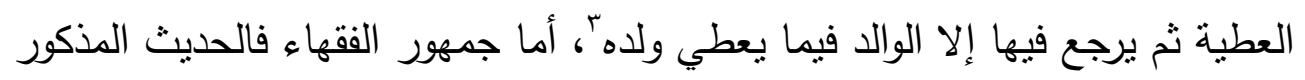

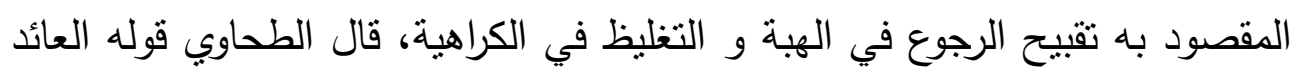

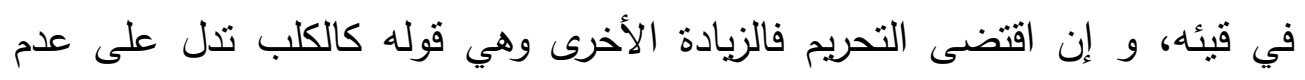
ا الحديث منفق عليه : أخرجه البخاري في كتاب: الهبة باب هبة الرجل لامر أتهه و المر أة لزوجها

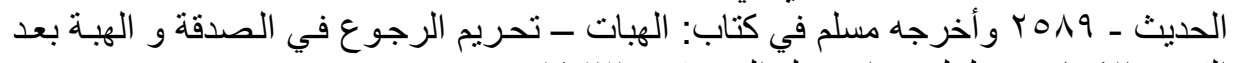

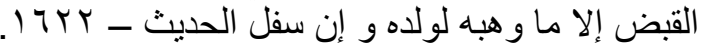

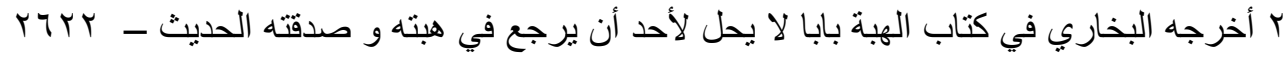

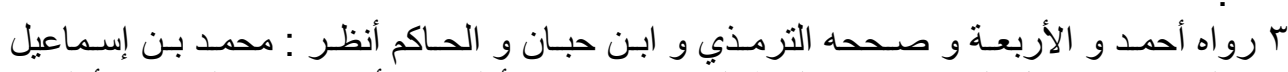

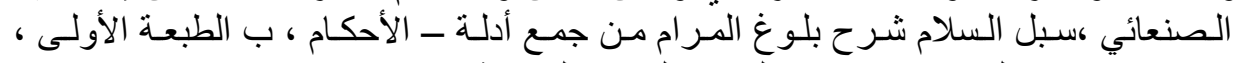

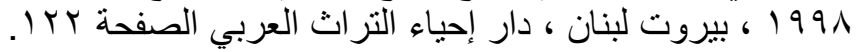


التحريم، لأن الكلب غير متعبد، فالقيء ليس حراما عليه والمراد التنزه عن فعل شيء يشبه فعل الكلب'، و يستذل الجمهور على جواز الرجوع في الهبة بدليلين :

أما الأول ففي الكتاب : يقول سبحانه وتعالى : " وإذا حييتم بتحية فحيوا بأحسن منها أو ردوها"، والتحية تستعمل في معان ثلاث : السلام والثناء والهدية ، والمراد بقوله تعالى " أو ردوها " هو المعنى الثالث لأن الرد إنما يتحقق في الأعيان لا في الأغراض ، لأنه عبارة عن رد الثيء وهذا لا بتصور في الأعراضّـ أما الدليل الثاني فيتمثل في إجماع الصحابة ، فقد روي عن عمر وعثمان وعلي وعبد الله بن عمر وأبي الدرداء وغيرهم رضي الله عنهم أنهم أجازوا الرجوع في الهبة وقولهم هذا إجماعا لأنه لم يخالفهم أحد؛.

وعليه فلابد لنا هنا من التقريق بين حالتين، الأولى: حكم الرجوع قبل القبض، والثانية: حكم الرجوع بعد القبض، وسوف نتتاول الحالثين على النحو التالى.

\section{الـفـرع الأول}

حكم الرجوع فى عقد الهبة قبل القبض الاول

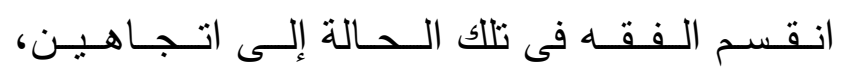

الإتجاه الأول برى أن الهبة قبل القبض تجوز، وهذا هو رأى جمهور الفقهاء، وذلك لأن عقد الهبة غير لازم، أى أنه يجوز للواهب أن يرجع فيه، فلا يمكن للموهوب له إجبار الواهب على تسليم الثئ محل عقد الهبة(ه).

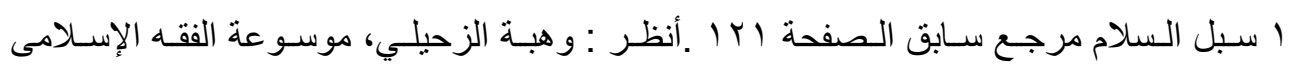

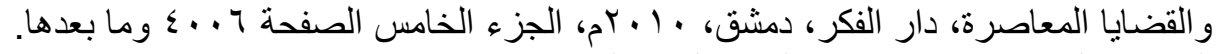

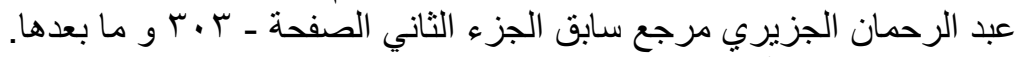

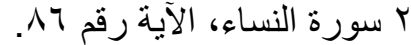

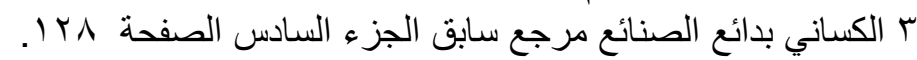

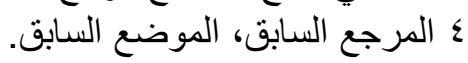
ه د. مصطفى احمد عبدالجو اد حجازى، الحكام الرجوع القضائى فى الهبة، مرجع سـابق، صـــــ 


$$
\text { ودليل جمهـور الفقهاء فى ذلك: }
$$

أولاً: قول الرسول صلى الهه عليه وسلم " يقول ابن آدم مالى مالى، قال: وهل

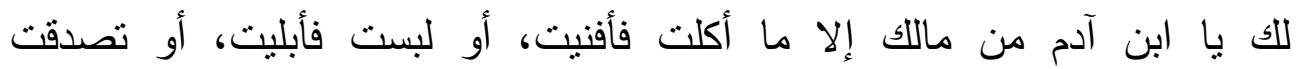
فأمضيث"'

وجه الدلالة: دل الحديث بمفهومه على نوقف لزوم الصدقة على الإمضاء،

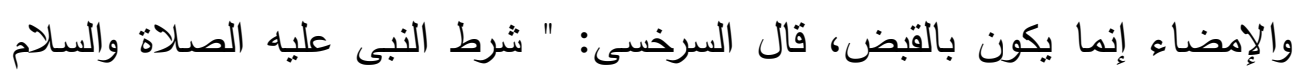

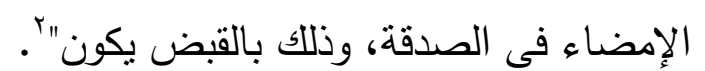

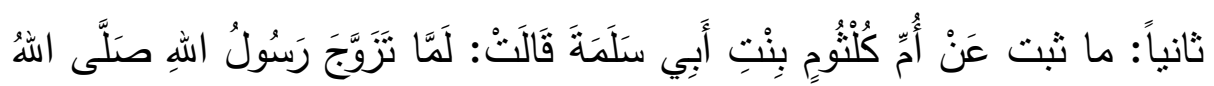

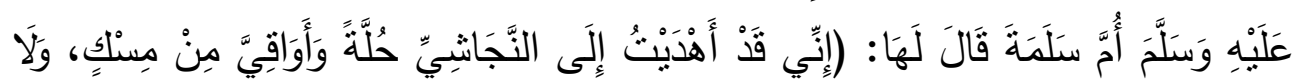

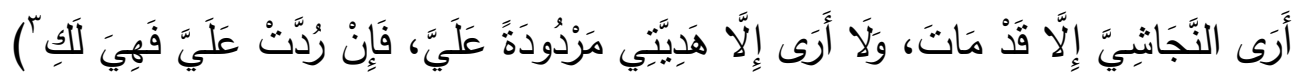

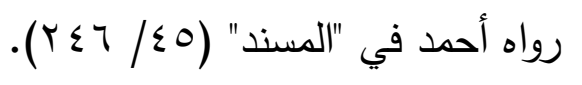

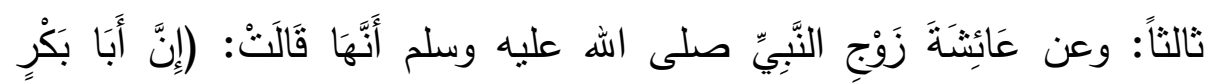

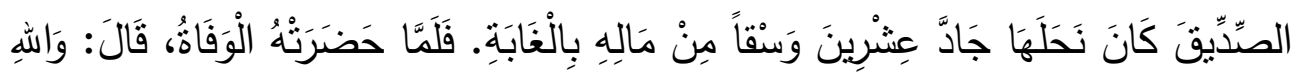

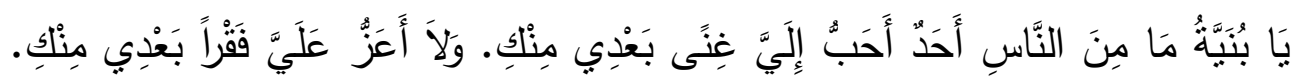

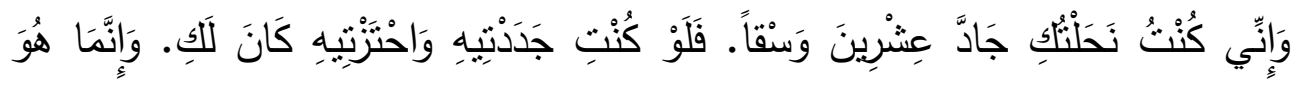

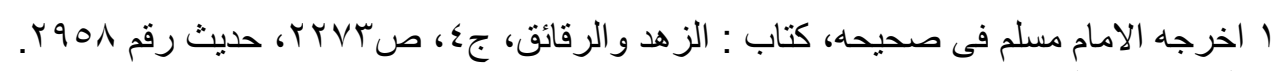

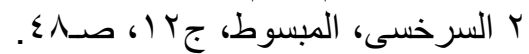

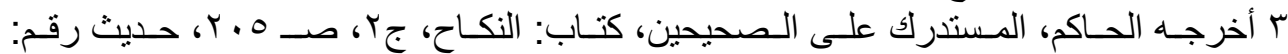

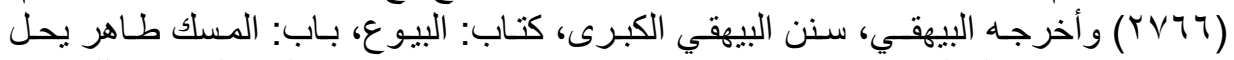

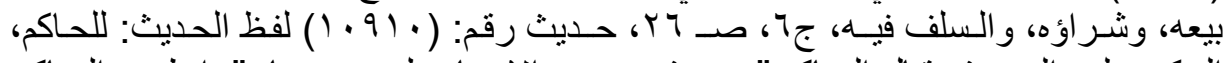

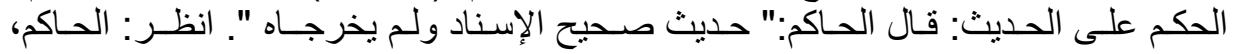

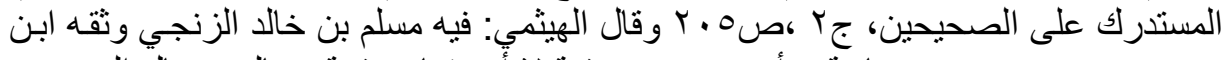

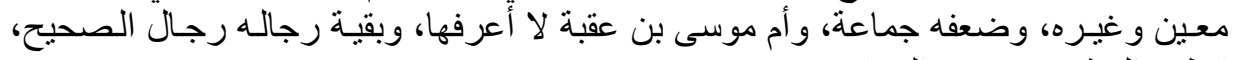

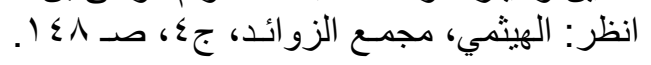




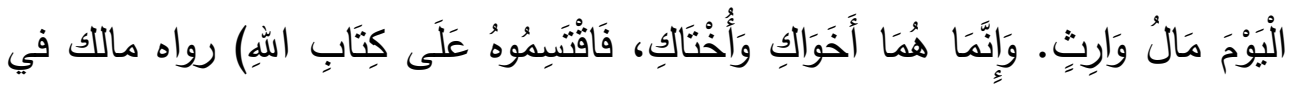

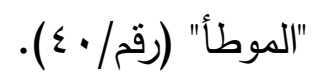

رابعاً: ما رواه أبو بردة أن عمر بن الخطاب رضى الله عنه قضى فى الأنحال،

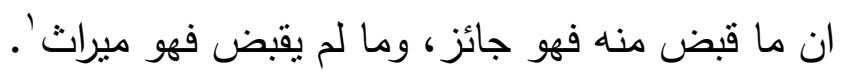

وفي هذه الأحاديث دليلٌ صريحُ على أن الهبة لم تلزم، ولم يثبت نقل ملكيتها

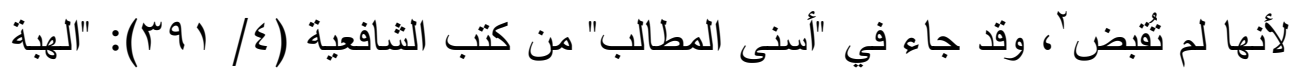
لا تلزم إلا بالقبض"، فهذه الأقوال تفيد بجواز الرجوع فى الهبة قبل قبضها من جانب الموهوب له.

أما الإتجاه الثانى فيرى أن الرجوع فى الهبة قبل القبض لا تجوز، وهذا هو رأى المالكية على المشهورّ، وبه قال الظاهربة؛؛، وقال هذا الاتجاه أن عقد الهبة يُلْزِم بمجرد العقد أى بمجرد صدور القبول موافقاً للإيجاب على شكلٍ صحيح، ويتم بالقبض، وعليه فليس للواهب أن يرجع فى الهبة بعد العقد.

أى أن الهبة قبل القبض عند أنصار هذا الاتجاه عقد لازم بمجرد إبرام العقد، أى تطابق الإيجاب والقبول بين الواهب والموهوب له، ومن ثم يجب على الواهب أن يُسلِم الثئ الموهوب إلى الموهوب له بمجرد إبرام عقد الهبة، فإن لم يفعل جاز

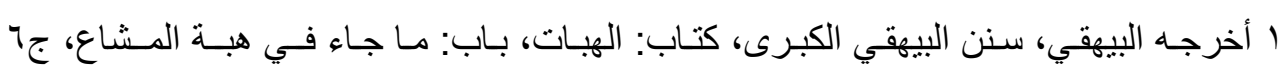

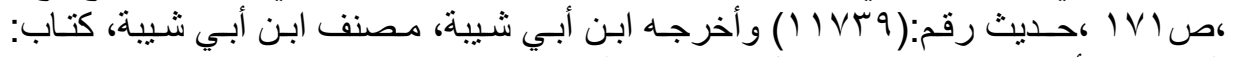

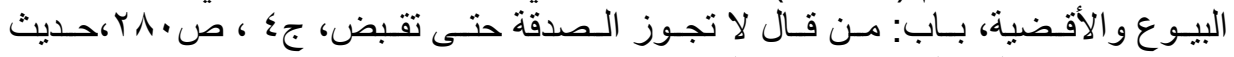

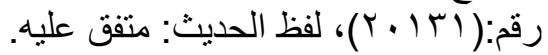

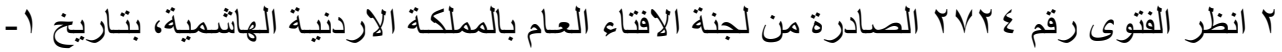

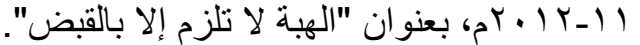

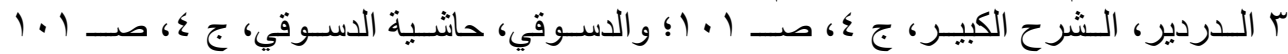

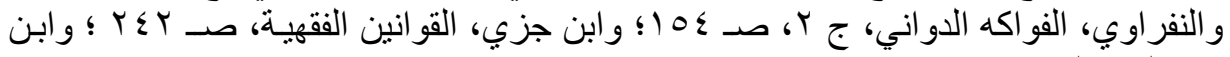

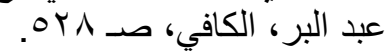
ع ابن حزم، المحلى، ج 9، صـا 
للموهوب لله إجباره على التسليم أو قبض الثئ الموهوب بغير إذن الواهب لأن ملكية الثئ الموهوب يكون قد انتقلت إليه بمجرد العقد' . وقد استدلوا على هذا الرأى بأدلةٍ من الكتاب والسنة والقياس، وهم:

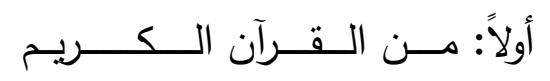

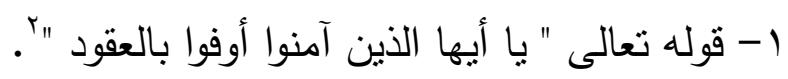

ووجه الدلالة هنا أن الآية عامة فى وجوب الوفاء بالعقود، ولا خلاف أن الهبة عقد من العقود، فيلزم الوفاء، بمجرد صدور القبول موافقا للايجاب، دون توقف على القبض"، ويجاب على ذلك أن هنا إنما يحمل على العقود اللازمة، والهبة فى اصلها ما هى إلا تبرع، واله تعالى يقول " ما على المحسنين من سبيل "؛. ثنانياً: من السنة النبوية الثريفة ولهي

1 حدثا عبداله بن يوسف، أخبرنا مالك بن أنس، عن زبد بن أسلم، عن أبيه، قال: سمعت عمر رضى الله عنه، يقول: حملت على فرس فى سبيل الله فأضاعه الذى كان عنده، فأردت أن اشتريه، وظننت انه يبيعه برخص، فسألت النبى صلى الله عليه وسلم، فقال: ( لا نتنزى ولا تعد فى صدقتلك، وإن أعطاكم بدرهم، فإن العائد فى

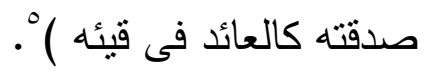
r- حدثنا مُسدد ، ثنا بشر بن المفضل، ثنا غالب القطان، عن رجل، عن أبيه، عن جده، انهم كانوا على منهل من المناهل، فلما بلغهم الإسلام جعل صاحب الماء ا د. حسن محمد بودى، ، موانع الرجوع في الهبة "في الفقه الإسلامي والقانون الوضعي"، مرجع

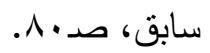

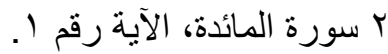

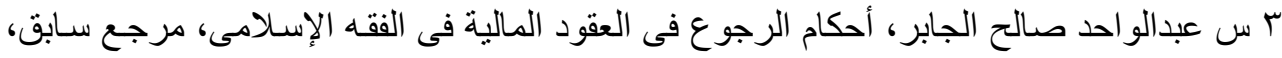
صد

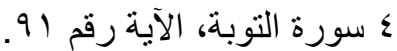

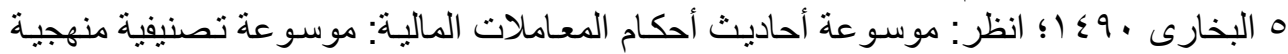

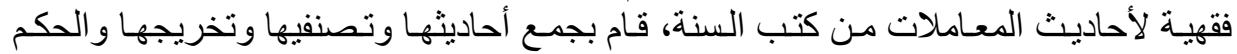

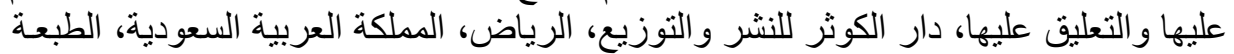

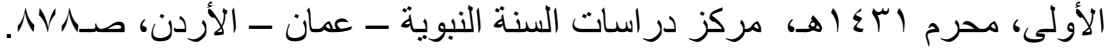


لقومه مائة من الإبل على ان يسلموا، فأسلموا، وقسم الابل بينهم، وبدا له أن يرتجعها منهم، فأرسل ابنه الى النبى صلى الله عليه وسلم، فقال له: ائتِ النبى صلى الله عليه وسلم، فقل له: إن أبى يقرئك السلام، وإنه جعل لقومه مائة من الإبل على أن بيلموا، فأسلموا، وقسم الإبل بينهم، وبدا له أن يرتجعها منهم، أفهو أحق بها، ام هى؟ فإن قال له نعم، أو لا، فقل له: أن أبى شيخ كبير وهو عريف الماء، وأنه يسألك أن تجعل لى لى له العرافه بعده، فأتاه فقال: إن أبى يقرئك السلام، فقال: ( وعليك وعلى أبيك السلام )، فقال: إن أبى جعل لقومه مائة من الابل على أن يسلموا، فأسلموا وحسن إسلامهم، ثم بدا له أن يرتجعها منهم، فهو أحق بها منهم، فإن هم أسلموا فلهم إسلامهم، وإن لم لم يسلموا قوتلوا على الاسلام)، فقال: إن أبى شيخ كبير وهو عريف الماء، وإنه يسألك أن تجعل لى العرافة بعده، فقال: ( إن العرافة حق ولابد للناس من العرفاء، ولكن

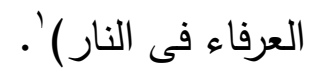

r- حدثنا مسدد، ثنا يزيد - يعنى: ابن زريع، ثنا حسين المعلم، عن عمرو بن شعيب، عن طاوس، عن ابن عمر، وابن عباس، عن النبى صلى الله عليه وسلم، قال: ( لا يحل لرجل أن يعطى عطية، أو يهب هبة، فيرجع فيها، إلا الوالد فيما يعطى ولده، ومثل الذى يعطى العطية، ثم يرجع فيها، كمثل الكلب يأكل، فاذا شبع

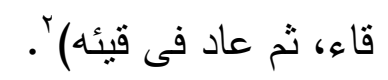

ع- أخبرنا زكريا بن بحيى، قال: حدثنا عبدالجبار بن العلاء، قال: حدثا سفيان، عن ابن ابى نجيح، عن طاوس، لعله عن ابن عباس، قال: لا رُقبى، فمن

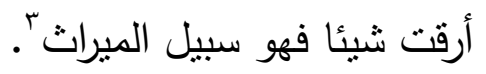


0- حدثنا على بن محمد، ومحمد بن اسماعيل، قالا: ثنا وكيع، ثثا ابراهيم بن اسماعيل بن مجمع بن جارية الاتصارى، عن عمرو بن دينار، عن ابى هريرة، قال:

قال رسول الله صلى الله عليه وسلم : ( الرجل أحـــق بهبته ما لم يثب منها )' . هذا ونحن من جانبنا نميل الى الرأى الثانى، لوقوة ووجاهة الادلة والاسانيد التى ساقها، وعليه فان الاصل العام فى هذا الموضوع هو عدم قابلية الرجوع فى عقد الهبة إلا فى استثناءات ضيقة، ألا وهى رجوع الابوين.

\section{الـفـرع الثـانــى}

\section{حكم الرجوع فى عقد الهبة بعد القبض}

انقسم الققه فى هذا الخصوص بين اتجاهين، الاتجاه الاول يرى عدم جواز

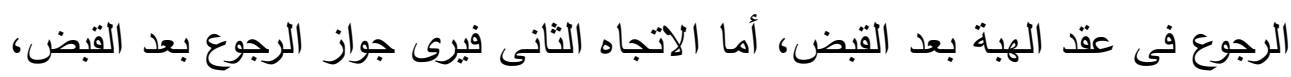
وسوف نتتاول كلا من الاتجاهين مع ادلة كلا منهما على النحو التالى.

الرأى الأول: يرى أنه لا يجوز الرجوع فى الهبة بعد القبض، عدم جواز الرجوع في الهبة بعد القبض، وهو قول جمهور الفقهاء من المالكية، والثافعية، والحنابلة؛؛ والظاهرية؛، باستتناء هبة الوالد لولده، فللوالد الرجوع فيما وهب لابنه ما لم يوجد مانع من موانع الرجوع، وزاد الثافعية جواز الرجوع لسائر الأصول على المشهور في

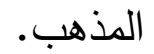

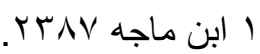

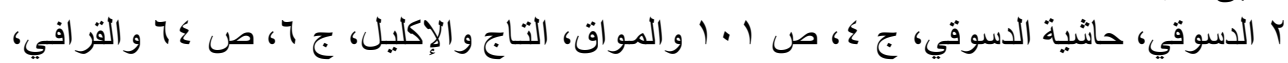

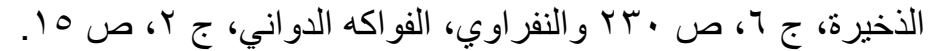

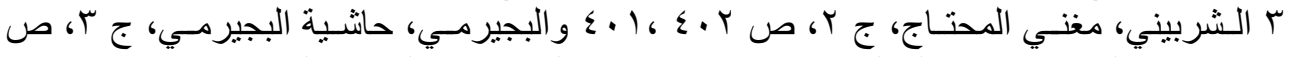

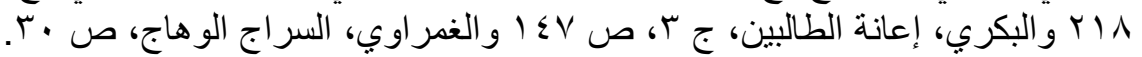

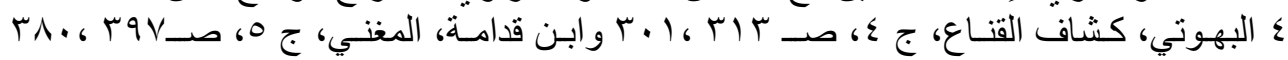

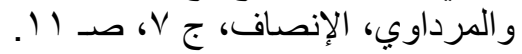

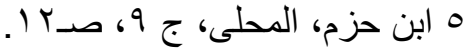


وقد استخلوا بما عن النعمان بن البشير رضي الله عنه أن أباه أنى به إلى إلى

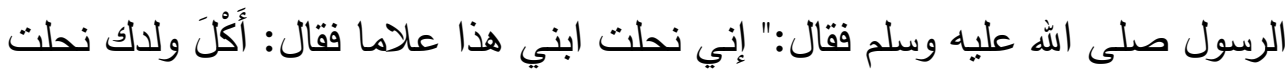
منله، قال لا، قال:فأرجعه"'، وفي هذا الحديث أمر من رسول الله صلى الله عليه وسلم إلى البشير بالرجوع في عطيته لابنه والأمر بالفعل مفاده الجواز .

كذلك فقد استخلوا بما روي عن ابن عباس رضي اله عنهما أن الرسول صلى الله عليه وسلم قال: "العائد في هبته كالكلب يقيئ ثم يعود في قيئه"، ففي هذا الحديث دلالة على تحريم الرجوع عن الهية، لأن القئ حرام، فالمشبه به مثلك. أيضاً ما رُوِيَ عن ابن عباس رضي الله عنهما أن الرسول صلى اله عليه وسلم

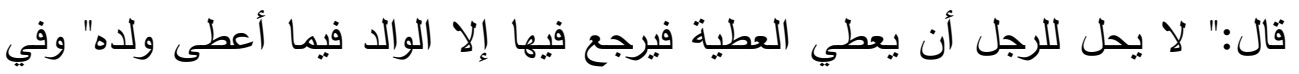

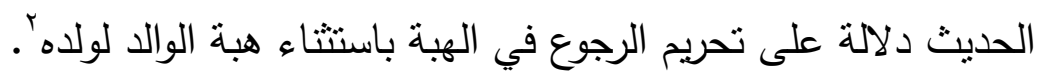
الرأى الثانى: يرى أنه يجوز الرجوع فى الهبة بعد القبض، برى أنصار الاتجاه أن الهبة بعد القبض عقد جائز في الأصل يجوز للواهب

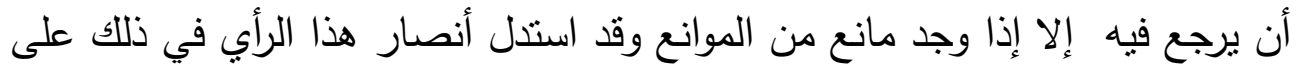

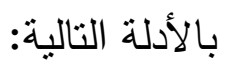

1- الحديث النبوى الثريف " حدثا مسدد حدثنا يزيد يعني ابن زريع حدثنا حسين المعلم عن عمرو بن شعيب عن طاوس عن ابن عمر وابن عباس عن النبي

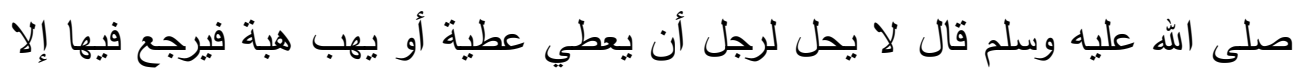

1 د. حسن محمد بودى، ، موانع الرجوع في الهبة "في الفقه الإسلامي والقانون الوضعي"، مرجع

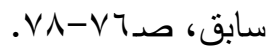

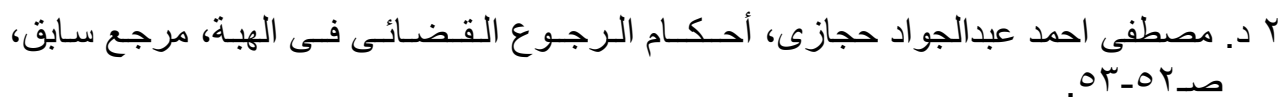


الوالد فيما يعطي ولده ومثل الذي يعطي العطية ثم يرجع فيها كمثل الكلب يأكل فإذا

$$
\text { شبع قاء ثم عاد في قيئه. 1" }
$$

r- ما روي عن أبي هربرة - رضي الله عنه- قال: قال رسول الله- صلى الله

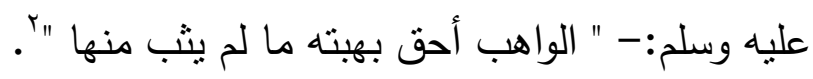

ب- ما روي عن الحسن عن سمرة أن النبي صلى الله عليه وسلم قال: "إذا كانت الهبة لذي رحم محرم لم يرجع فيها" فدل الحديث على أهمية الواهب في الرجوع

$$
\text { في هبته ما لم تصدر لذي رحم محرم. }
$$

ع - روي بإجماع عن عدد من الصحابة رضوان الله عليهم بثبوت حق الرجوع

في الهبة ولم ينتقل عن غيرهم خلاف. أن الهبة عطاء بغير مقابل ومن ثم فان الموهوب له لا يتضرر من رجوع الواهب عنها. أن الواهب إنما قصد من هبته غرضا بهاء معينا، فقد يهب لنيل الثواب من الله تعالى وقد يهب لتحقيق غرض دنيوي أو لأجل صلة الرحم وغيرها فان طلب الرجوع دل ذلك على أن الغرض من هبته لم يتحقق

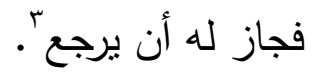

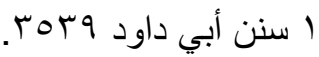

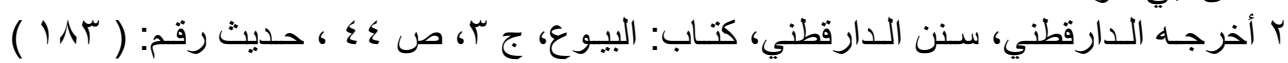

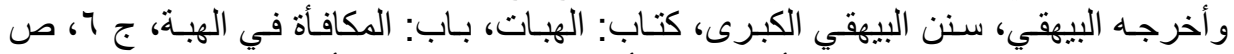

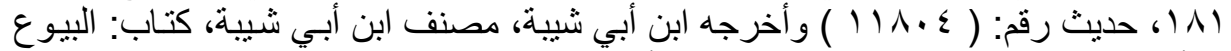

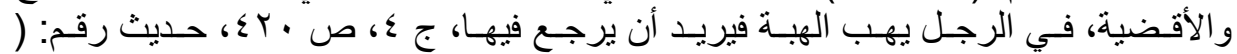

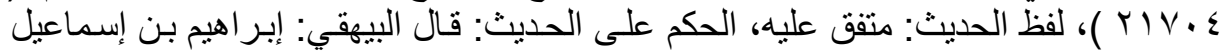

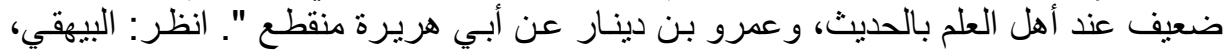

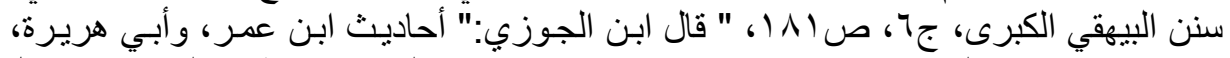

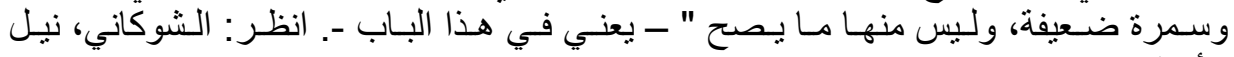

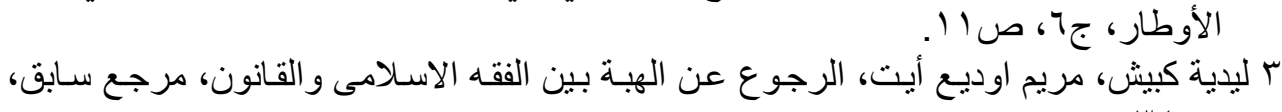


من النظر في آراء الفقهاء، ومناقثة ما استدلوا به من أدلة، نرى مع البعض' رجحان قول جمهور الفقهاء، القاضي بعدم جواز الرجوع في الهبة بعد القبض، إلا فيما بهب الوالد لولده؛ لأن الهبة في النهاية لا تخرج عن كونها عقد، واللهسبحانه وتعالى يقول: \$و يا أيها الذين آمنوا أوفوا بالعقود )، فإن أجيب بأن هذه الآية إنما تحمل على العقود اللازمة، والهبة ما هي إلا عقد تبرع، أجيب عنه: إنما يصدق ذلك على الهبة ما لم يحصل قبض لها، أما بعد القبض فلا؛ حفاظًا على استقرار المعاملات بين الناس.

\section{المطلب الـثنانـى}

\section{مشروعية الرجوع فى الهبة فى القوانين الوضعية}

سوف نتتاول حكم الرجوع فى الفقه فى التشريعات العربية المقارنة، وذلك على

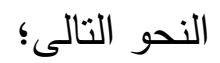

\section{الـــــــع الأول}

\section{حكم الرجوع فى الهبة فى التشريع المصرى}

لقد سار القانون المدنى المصرى على المذهب الحنفى بجواز الرجوع فى الهبة إلا إذا قام مانع من الرجوع، حتى لا يغير الأحكام التى استقرت فى عهد القانون المدنى القديم'، ولكنه آشترط فى حق الرجوع بغير التراضى وجود عذر مقبول، فقرر أن الأصل جواز الرجوع فى الهبة بالتراضى، شأن الهبة فى ذلك شأن أى عقدٍ آخر ،

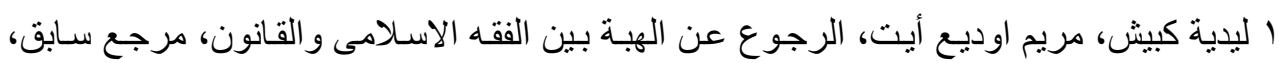

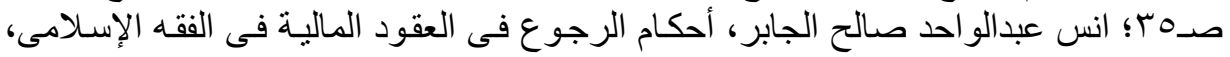

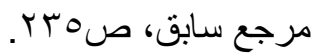

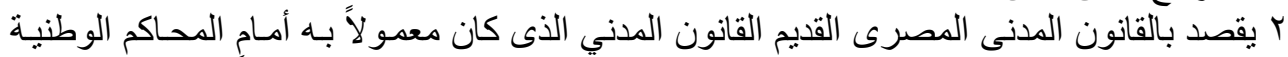

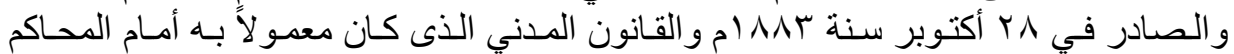

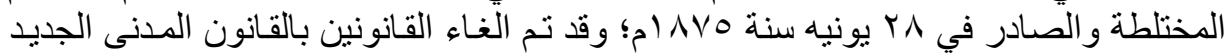

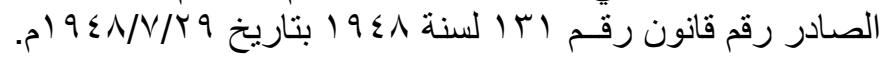


ولكن الهبة تتميز عن العقود الأخرى بأن الواهب يجوز له أن يرجع فى الهبة دون رضاء الموهوب لله، إذا استتد فى ذلك إلى عذرٍ مقبول يقره القضاء ولم يوجد مانع من الرجوع، ويترتب على الرجوع فى الهبة بالتراضى أو بالتقاضى أن تعتبر الهبة كأن لم تكن، بما بستتبع ذلك من نتائج' .

والرجوع فى القانون المصرى يتم إما بالتراضى أو بالتقاضى، وبالنسبة للرجوع بالتراضى فقد نصت الفقرة الأولى من المادة رقم . .0 من القانون المدنى المصرى على أنه " يجوز للواهب أن يرجع في الهبة إذا قبل الموهوب له ذلك ".

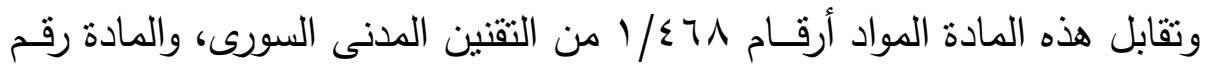
• ب T مـن التقنين المدنى العراقى.

هذا وبُعتَبر اتفاق الأطراف على الرجوع فى الهبة هنا إقالة، ولا تتميز الهبة فى ذلك عن سائر العقود سوى أن لهذه الإقالة أثراً رجعياً يجعل الهبة كأن لم تكن، لذلك وجب حماية حقوق الغير حسن النية التى اكتسبها من الموهوب له قبل الإقالة، والإقالة جائزة ولو وُجدَ مانع من موانع الرجوع، ولو لم يكن لدى الواهب أى عذر

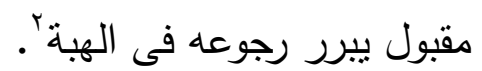

أما بالنسبة للرجوع بالنقاضى، فقد اشترط القانون هنا ثلاثة شروط، كما نصت الفقرة الثانية من المادة رقم . .0 والتى نصت على أنه " فإذا لم يقبل الموهوب له

ا د. عبدالرزاق السنهورى، الوسبط فى شرح القانون المدنى، الجزء الخـامس، العقود التى تقع

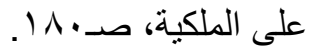

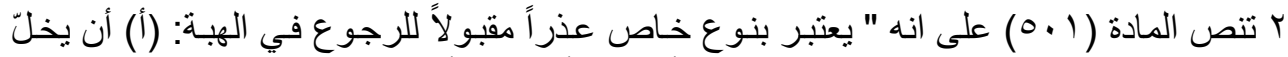

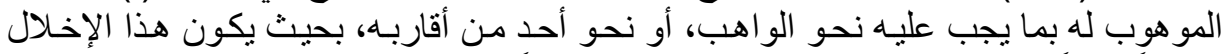

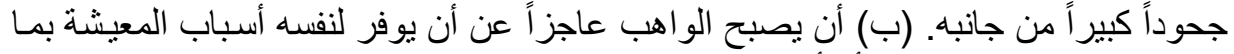

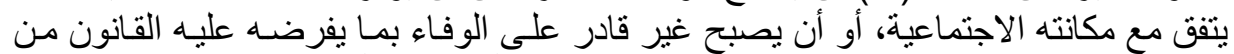

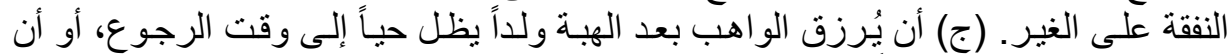

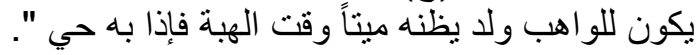


جاز للواهب أن يطلب من القضاء الترخيص له في الرجوع، متى كان يسنتد في ذلك

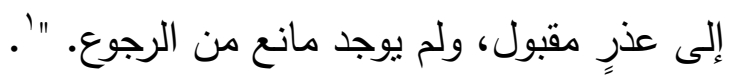

\section{الشرط الأول: الأعــذار المبـررة للـرجـوع فـى عـقـد الـهبـة}

وهذه الأعزار المقبولة لا يُتْركَك أمر تقديرها إلـى تقدير الواهب وحده، بل يراقبه فيه القضاء، فإذا رأى القاضى أن العذر الذى يقدمه الواهب للرجوع فى هبته عذر مقبول، أقره عليه وقضى بفسخ الهبة، وإلا امتتع من إجابة طلبه وأبقى الهبة قائمة. فالرجوع بالتقاضى فى الهبة هو فسخ قضائى لها بناءً على طلب الواهب، يسوغه عذر مقبول متروك إلـى تقدير القاضى كما هو الأمر فى فسخ العقد بوجهِ عامَّ. ويعتبر من الأعذار المبررة للرجوع فى الهبة قضاءً فى القانون المصرى أن يخل الموهوب له بما يجب عليه نحو الواهب أو نحو أحد من أقاربه بحيث يكون هذا الإخلال جحودا كبيراً من جانبه، أن يصبح الواهب عاجز عن أن يوفر لنفسه أسباب المعيثة بما يتفق مع مكانته الاجتماعية، وأن يصبح غير قادر على الوفاء بما

ا وفى هذا الشأن قررت محكمة النقض المصرية بأنه " لمـا كان يجوز للو اهب طبقاً لنص المـادة

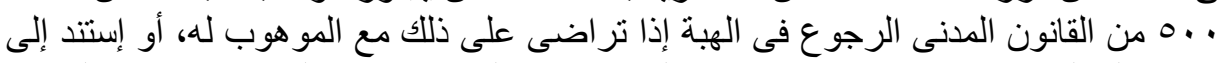

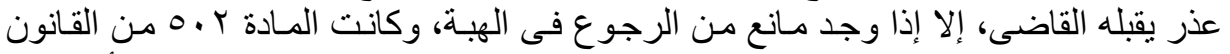

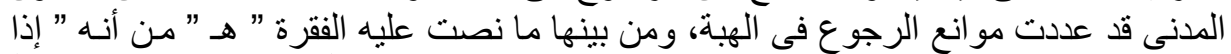

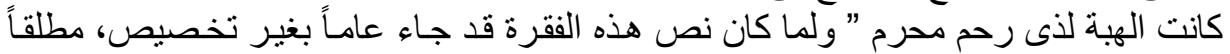

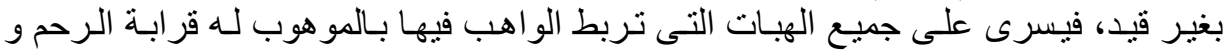

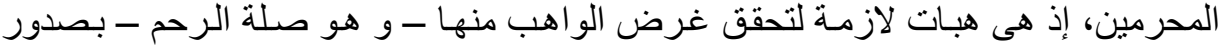

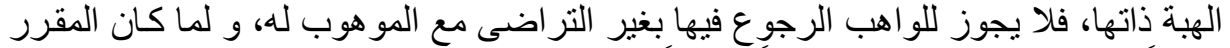

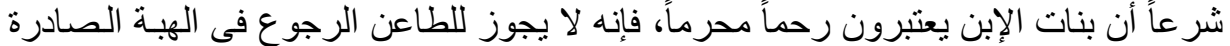

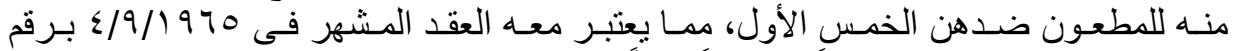

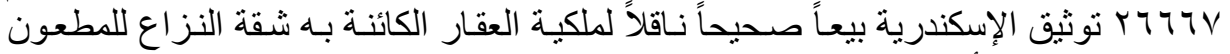

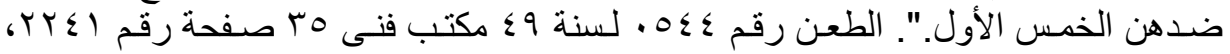

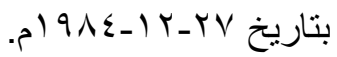

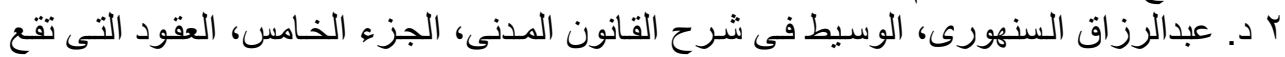

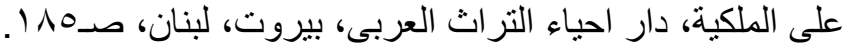


يفرضه عليه القانون من النفقة على الغير ، أن يرزق الواهب بعد الهبة ولداً بظل حياً

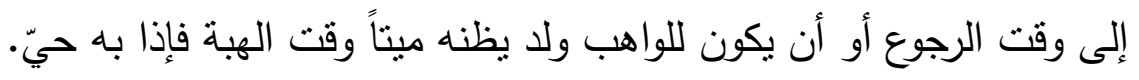

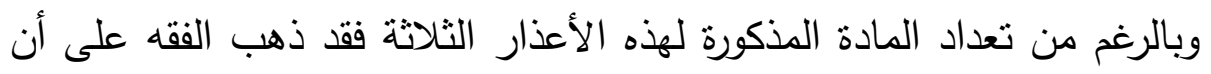

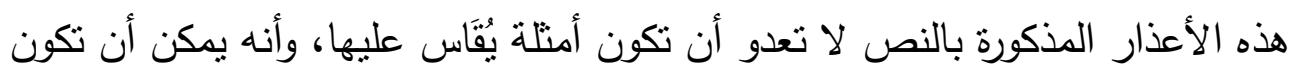

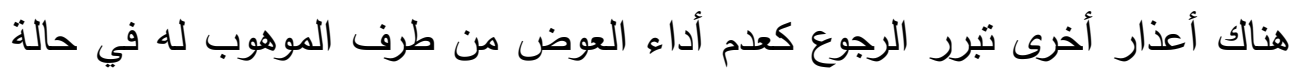

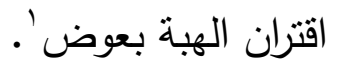

وجاءت المادة ش؟؛ مدنى سورى على نفس الصياغة، وتطابق هذه المواد

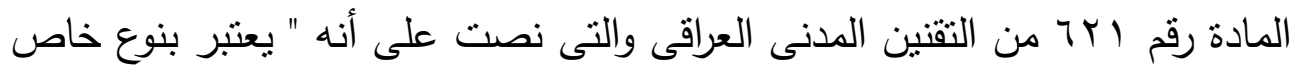

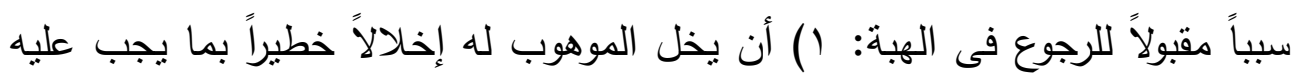

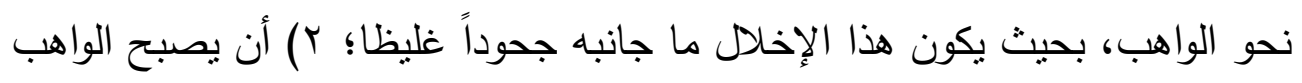

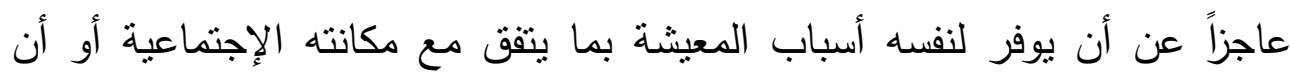

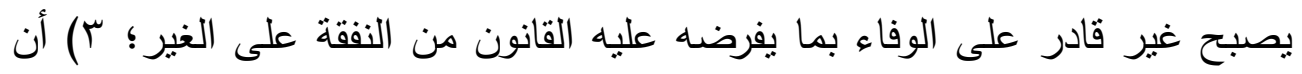

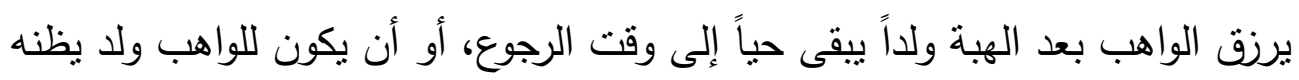

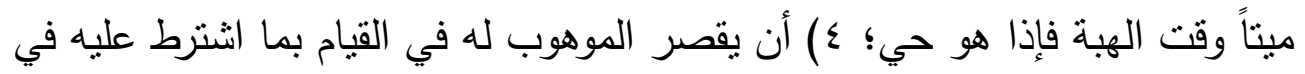
العقد من إلتـزامـات بدون عذرٍ مقبول.

$$
\text { وسـوف نتنـاول تـلك الأعــار الـواردة عـلـى الـنـــو الـتــلـى: }
$$

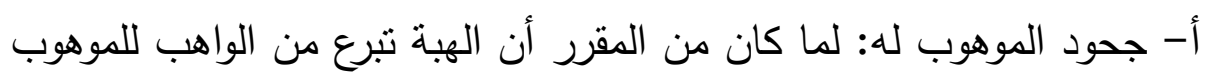

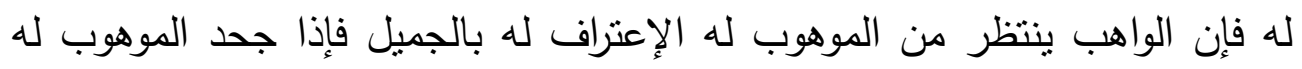

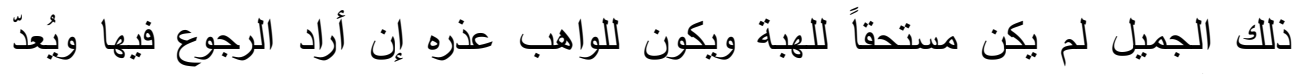

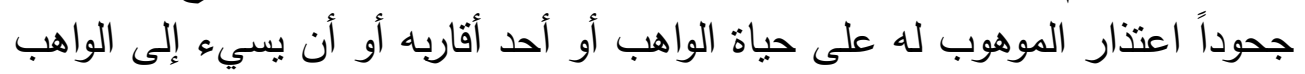

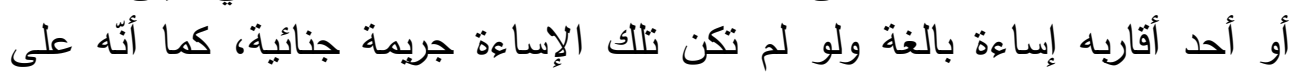

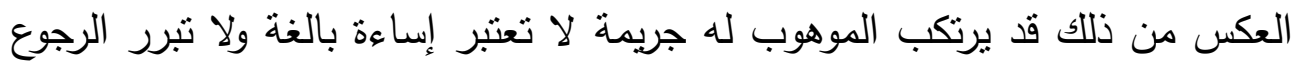

$$
\begin{aligned}
& 1 \text { د. عبدالرزاق السنهورى، الوسيط في شرح القانون المدنى، الجزء الخامس، العقود التى تقع بقع } \\
& \text { على الملكية، مرجع سابق، صد.. ب و وما بعدها. }
\end{aligned}
$$




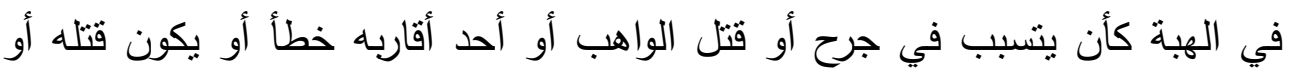

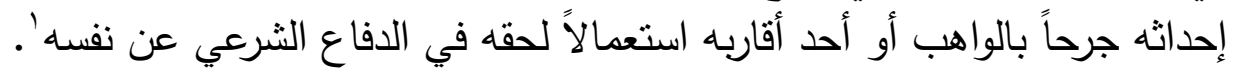

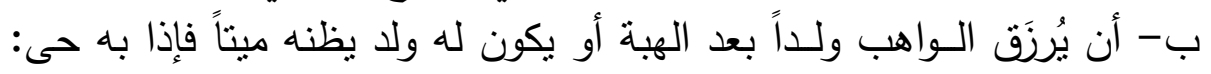

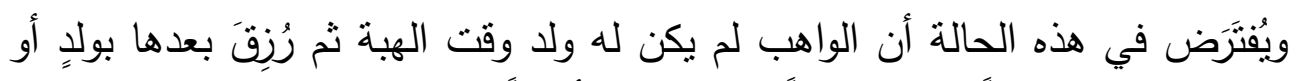

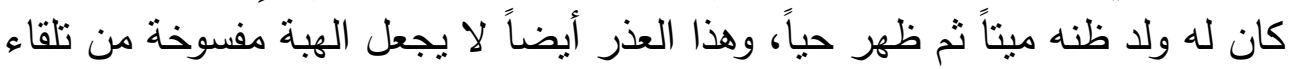

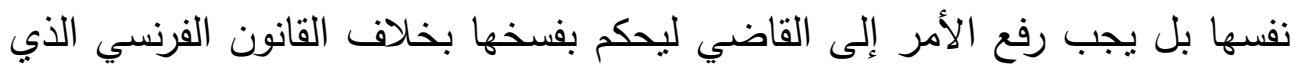
يجعل الهبة مفسوخة من تلقاء نفسها.

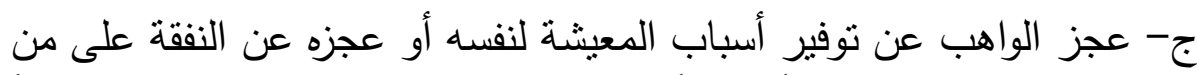

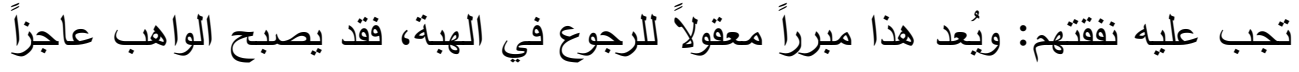

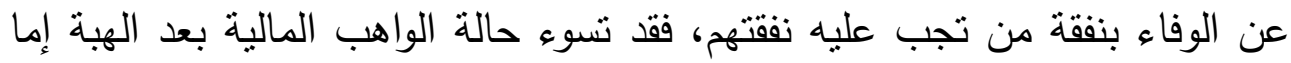

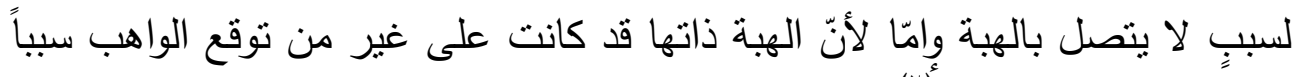

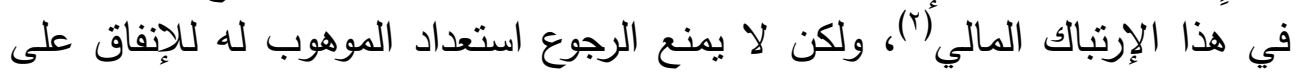

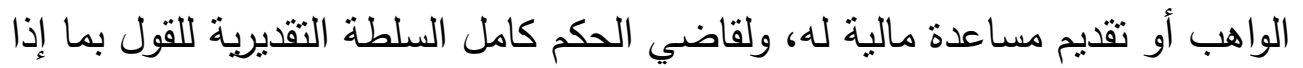

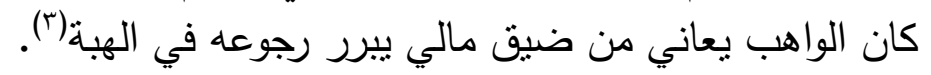

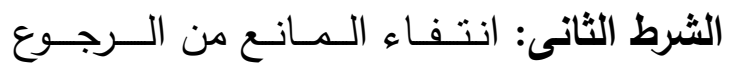

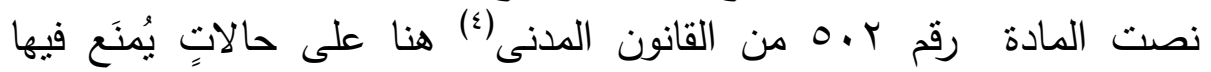

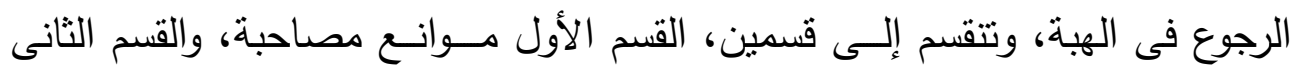

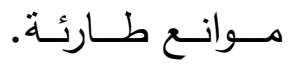

ا د. محمـد كمـال حمدى، المواريـث والهبـة و الوصـية، دار المطبوعـات الجامعيـة، الاسكندرية،

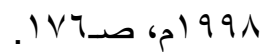

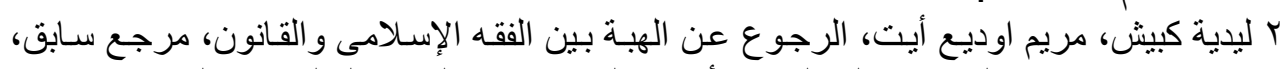

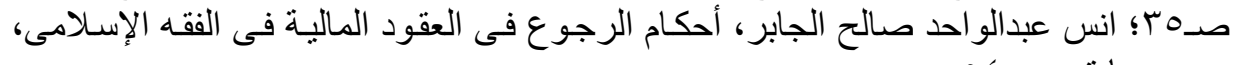

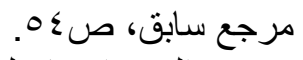

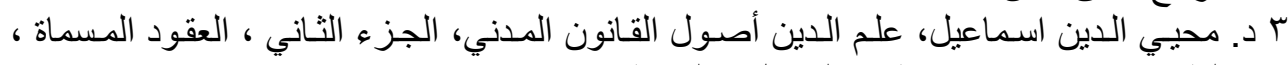

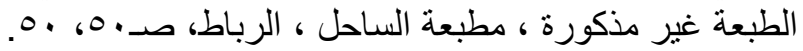

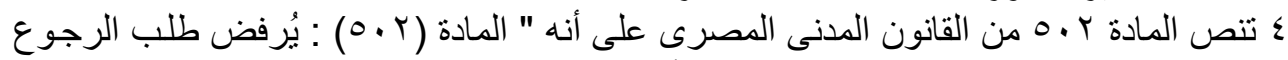

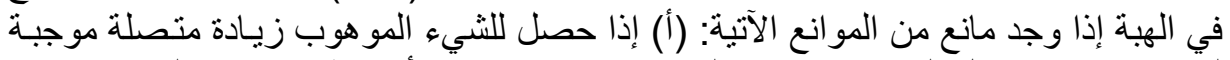

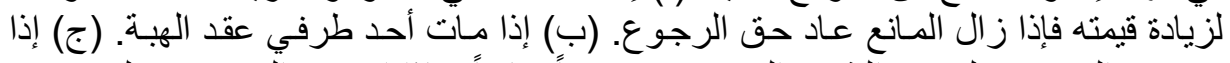

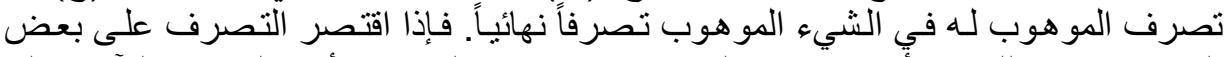

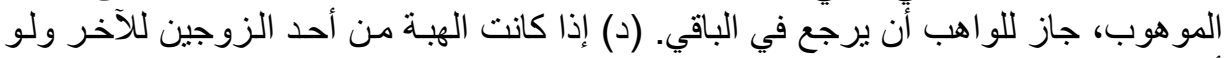

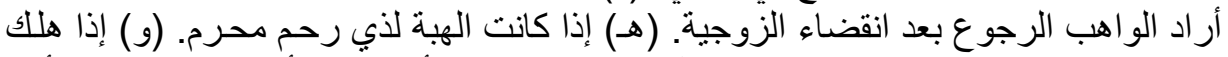

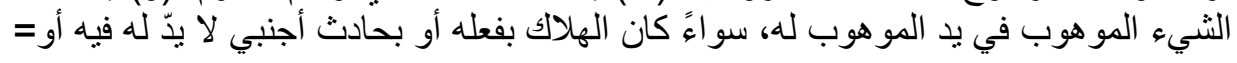




$$
\text { أ- الـــــــوانـع الـمـصـاحـبـة: }
$$

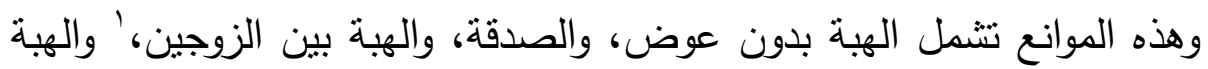

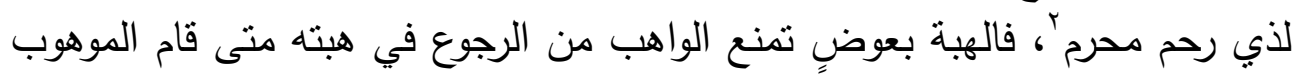

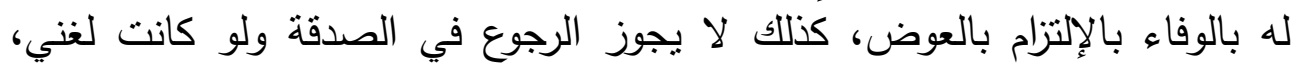

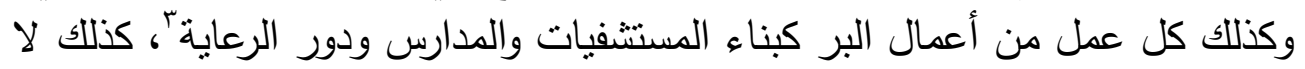

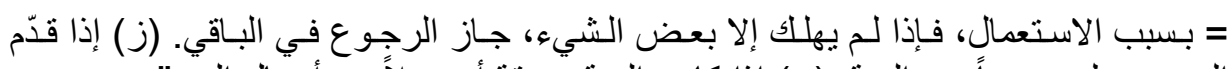

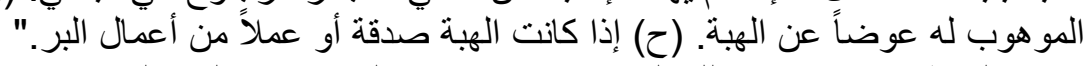

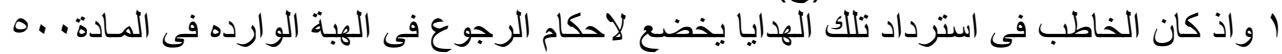

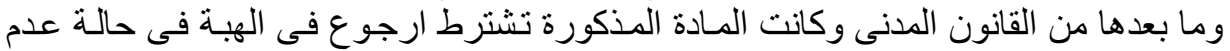

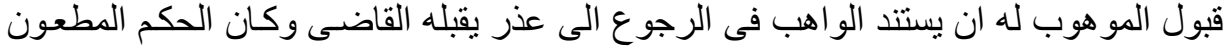

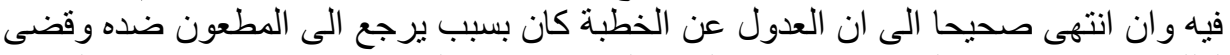

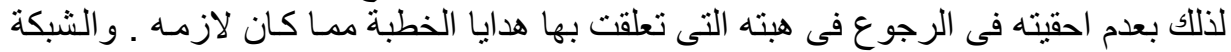

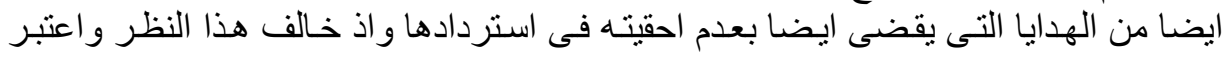

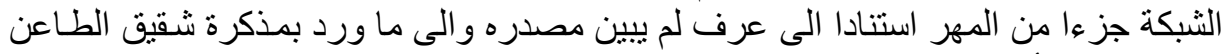

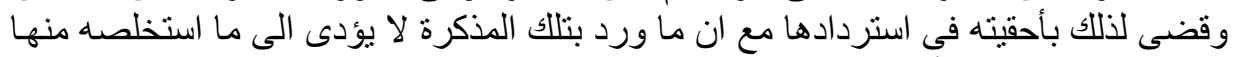

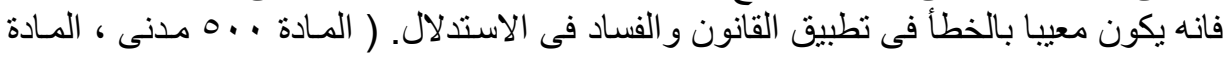

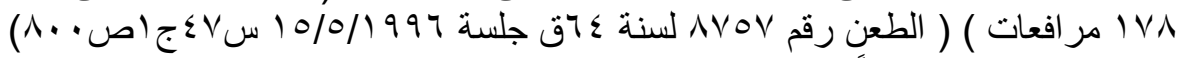

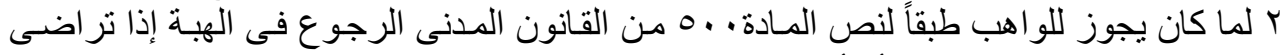

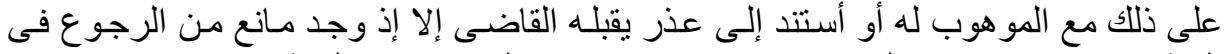

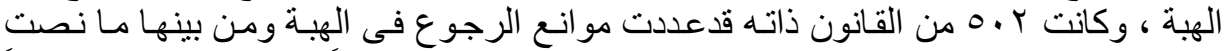

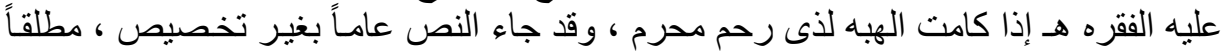

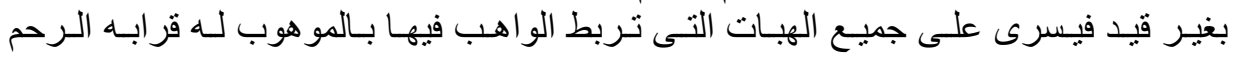

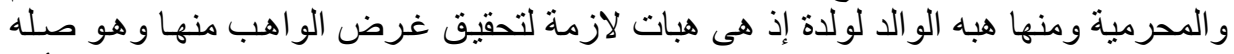

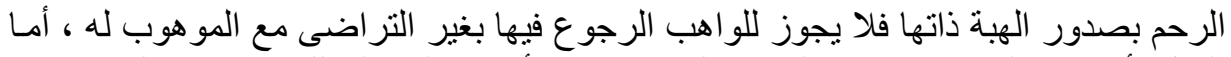

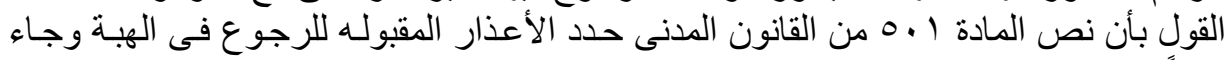

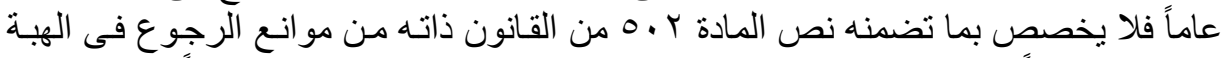

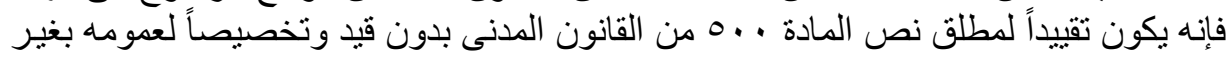

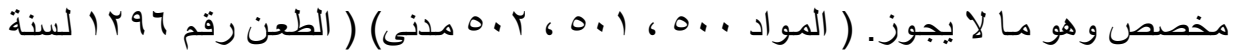

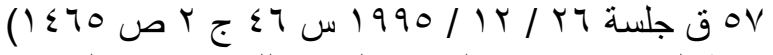

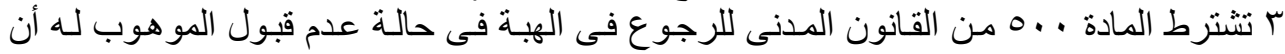

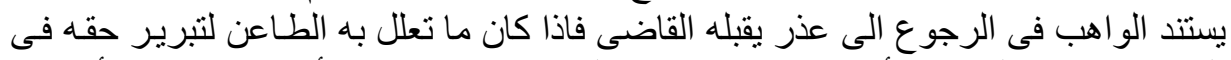

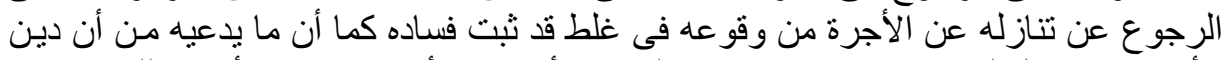

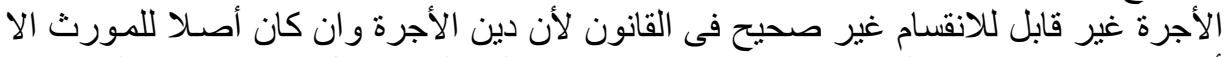

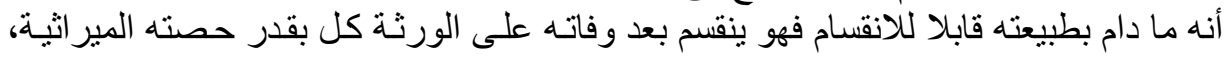

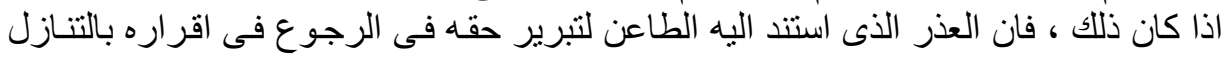

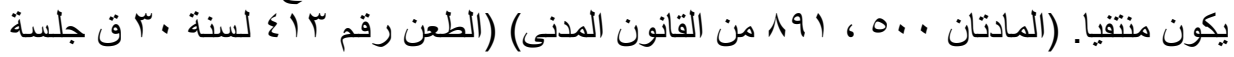
(1 TVA (1). 
يجوز رجوع أحد الزوجين فيما وهبه للآخر أثناء الزوجية، أما الهبة السابقة للزوجية'

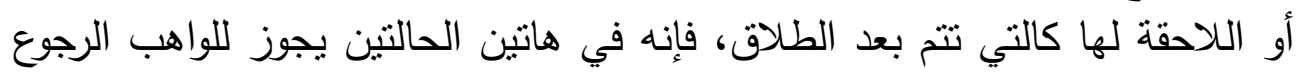
في هبته، كذلك لا يجوز الرجوع في الهبة الصادرة لذي رحم محرم، وعلى ذلك تكون الهبة لذي رحم غير محرم كأولاد الخالات والأخوال والعمات يجوز الرجوع فيها، كذلك

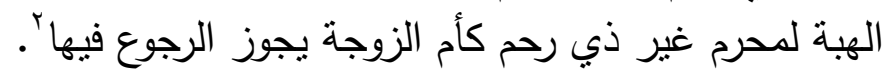

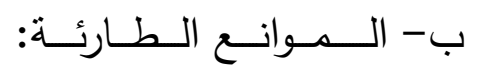

الموانع الطارئة هي التي تحدث بعد إنعقاد الهبة كوفاة أحد طرفيها، كذلك يُمنَع الرجوع في الهبـة إذا تصرف الموهوب لـه في الثيء الموهوب بـالبيع أو غيره مـن التصرفات الناقلـة للملك، كمـا يُمتَنَع الرجوع في الهبـة إذا زاد الشيء الموهوب زيـادة متصلة تزبد في قيمته.

وفى هذا تتص المادة رقم r • م من التقنين المدني المصري على ما يأتي " يُرفَض طلب الرجوع في الهبة إذا وُجْدَ مانع من الموانع الآتية: - إذا حصل للشيء الموهوب زيادة متصلة موجبة لزيادة قيمته، فإذا زال المانع

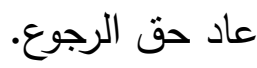
- إذا مات أحد طرفي عقد الهبة.

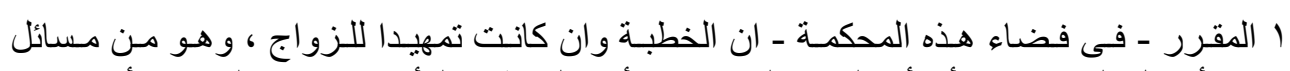

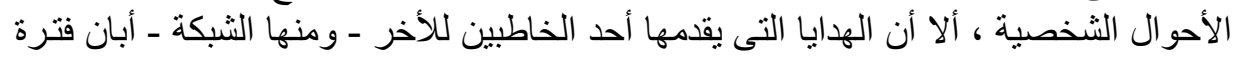

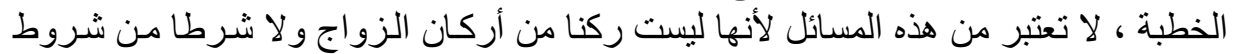

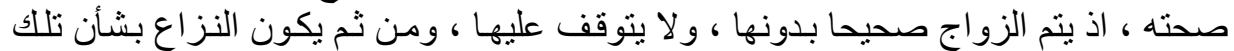

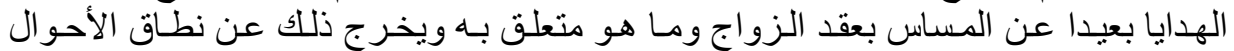

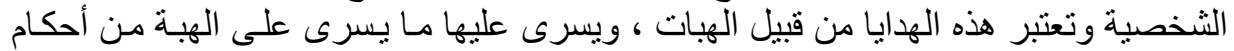

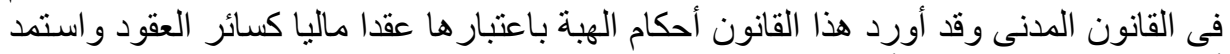

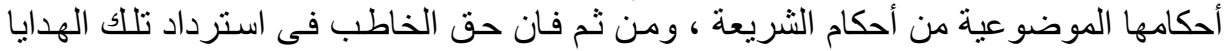

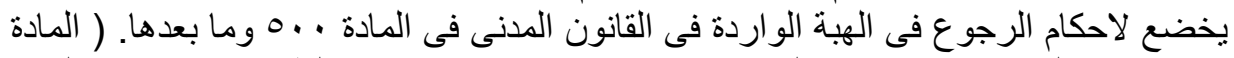

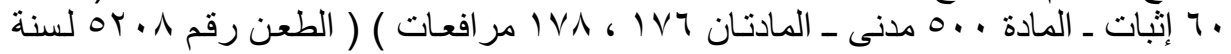

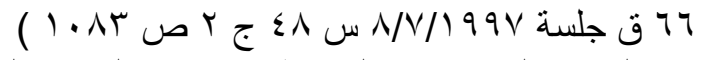

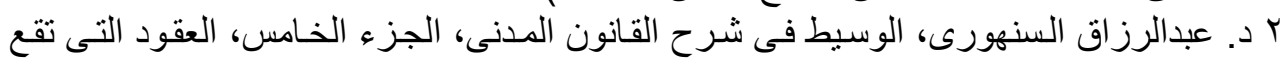

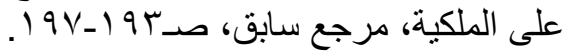


التصرف على بعض الموهوب، جاز للواهب أن يرجع في الباقي.

- إذا كانت الهبة من أحد الزوجين للآخر ولو أراد الواهب الرجوع بعد انقضاء

$$
\text { - إذا كانت الهبة لذوي رحم محرم. }
$$

- إذا هلك الثيء الموهوب في يد الموهوب له، سواء كان الهلاك بفعله أو الو لهاء

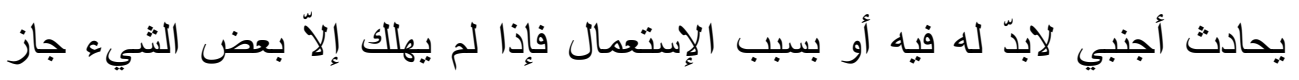

$$
\text { الرجوع في الباقي. }
$$

$$
\text { - إذا قدم الموهوب له عوضاً عن الهبة. }
$$

- إذا كانت الهبة صدقة أو عملاً من أعمال البرّ .

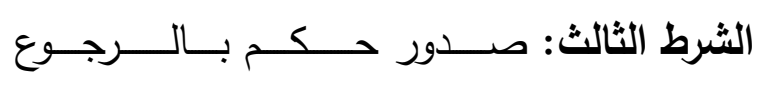

فمنى توافرت أسباب الرجوع في الهبة وانتقت الموانع فإن الهبة لا تُفَخخ تلقائيًا

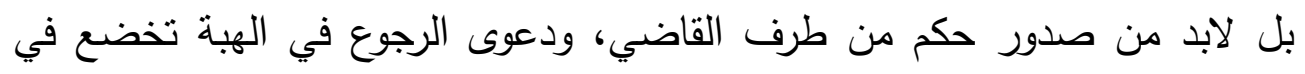

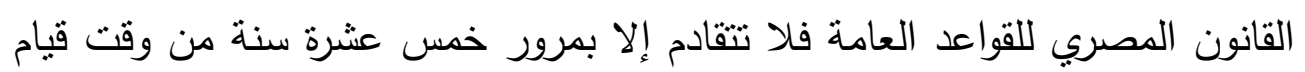

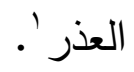

ويُشَرط لقبول الدعوى نوافر كافة الثروط العامة المنطلبة فى القانون

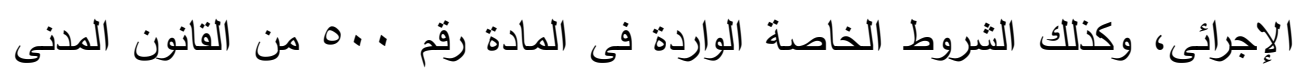

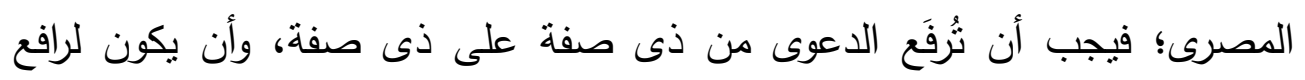
الدعوى مصلحة فى رفعها.

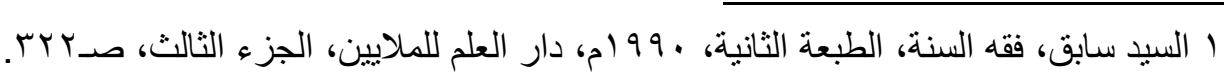


والجدير بالذكر أنه يترتب على الرجوع في الهبة بالتراضي أو التقاضي أن

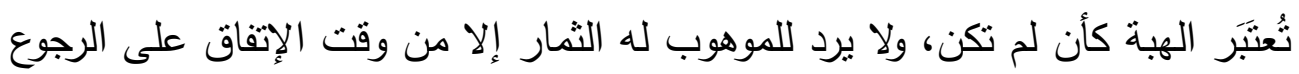
أو من وقت رفع الدعوى، وللموهوب له الرجوع على الواهب بجميع المصروفات الضرورية، أما المصروفات النافعة' فلا يجوز الرجوع فيها إلا بالقدر الذي زاد في قيمة الثيء الموهوب تأسيساً على المادة رقم بــ من التقنين المدني المصري، أما بالنسبة للغير فإن الهبة ليس لها أثر رجعي وأنه يتعين حماية حقوق الغير حسن النية.

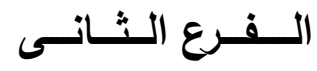

\section{حكم الرجوع فى الهبة فى التشريعات الوضعية المقارنة}

\section{الغصن الأول / بالنسبة للتشربع الفرنسي}

لقد أعطى القانون الفرنسى عقد الهبة قوة فى الالزام بحيث قرر بأن الاصل فيه

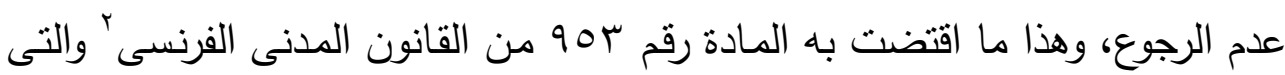
تنص على أن " الهبـة بين الاحياء لا يجوز الرجوع فيها....."، إذن فبمقتضى هذا النص لا يجوز الرجوع فى الهبة'.

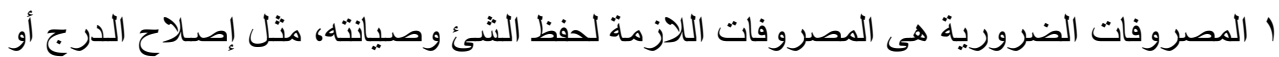

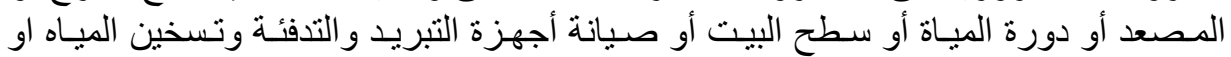

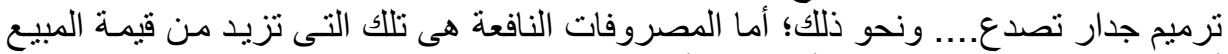

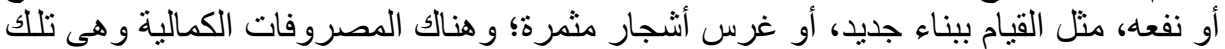
التى تنفق لزخرفة الثئ أو زينته، كزخرفة الأسقف او كساء الحوائط أو تتسيق الحديقة.

$r$ Art. 90r: "An inter vivos gift may be revoked only for non-performance of the conditions under which it was made, on account of ingratitude, and on account of unforeseen birth of children.".

ب ليدية كبيش، مريم أيت أوديع، الرجوع عن الهبة بين الفقه الاسـلامى والقانون، مرجع سـابق، 
والجدير بالذكر أن قاعدة عدم الرجوع فى الهبة ترجع الى مبدأ القانون الفرنسى

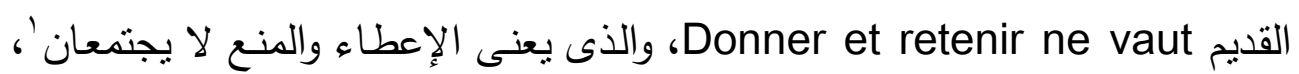
وإن كـان هذا المبـدأ لـم ينقل بحرفيته فى القـانون المـدنى الفرنسىى، فانـه توجد لـه

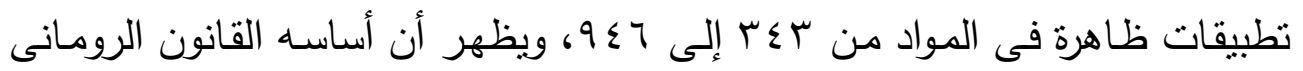
قبل عهد جيستتيان وما كانت الهبة تتتج آثارها إلا إذا نفذذت فلم تكن الهبة تنم إلا من الوقت الذى يتخلى فيه المتصرف فيه بالفعل على المال الذى يعطيه أى من وقت التسليم ومن ثم وحد المبدأ " الإعطاء والمنع لا يجتمعان" ولكن هذه العبارة أخذت فيما

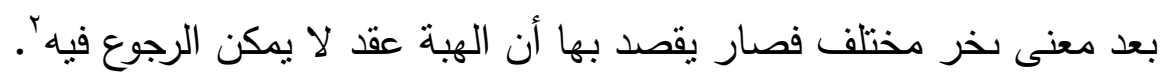

غير أن المششرع الفرنسى وبمقتضى نفس المـادة أجـاز الرجـوع فى الهبـة فى حالات ثنات وهم: (أ) حالة عدم تنفيذ الشروط المتفق عليها فى عقد الهبـة، (ب) حالة جحود الموهوب له، (ج) ولادة ابن للواهب، كما أجازت المادة 97 ـ 1 الرجوع فى

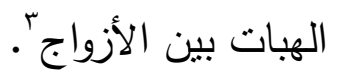

فقد أجاز القانون المدني الفرنسي الرجوع دائما في الهبات الجاريـة بين الزوجين سواء تلك التي حصلت بين أزواج المستقبل أو بمناسبة الزواج او خلال فترة الزواج،

' Notes de bas de pageSection YLa règle " donner et retenir ne vaut "§ I. Sens de la règle $\vee V Y$. Dépouillement actuel du donateur. - Cela signifie que le droit, objet de la donation, doit être acquis au donataire dès la donation. Mais cela ne signifie pas que le donataire doive être mis immédiatement en possession et jouissance des biens donnés. Ainsi, le donateur peut se réserver l'usufruit des choses données (art. $9 \leqslant 9$ ), sans que l'actualité du dépouillement soit méconnue.

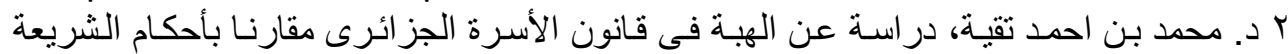

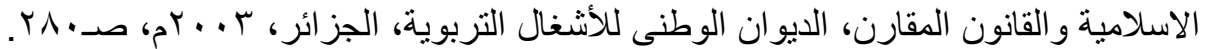

r Art. 1.97 : (Act of $1 \wedge$ Feb. 19ץ^) All gifts made between spouses, during the marriage, although named inter vivos, are always revocable. [repealed] Those gifts are not revoked by the unforeseen birth of children. 
ولم يستثن من ذلك إلا الهبات الجاريـة من الغير بسبب الزواج لمصلحة الزوجين

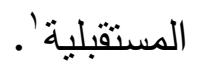

ومسن اسـتقراء النصوص عاليـه سـيظهر لنـا أن المشرع الفرنسىى أورد حـالات الرجوع عاليه على سبيل الحصر وليس المثال، وقد قيد الحالة الثانية بضرورة توافر حالة من ثلاثث وهما اذا اعتدى الموهوب لله على حياة الواهب، والحالـة الثانية إذا أسـاء الموهوب لـه معاملـة الواهب إسـاءة جسمية، والحالـة الثالثة والاخيرة اذا امتتع الموهوب له عن اعطاء الواهب نفقة، والجدير بالذكر ان البطلان بسبب الجحود لا يقع بقوة القانون، بل يجب رفع دعوى بذلك من قبل الواهب.

\section{الغصن الثانى / بالنسبة للتشريع السورى}

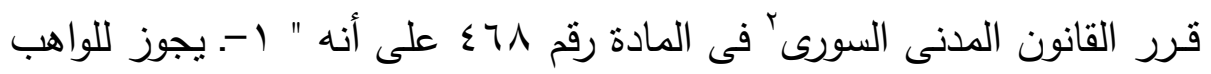
أن يرجع في الهبة إذا قبل الموهوب له ذلك، r- فإذا لم يقبل الموهوب له جاز للواهب أن يطلب من القضاء الترخيص له في الرجوع، منى كان يستتد في ذلك إلى عذر مقبول، ولم يوجد مانع من الرجوع. "، ويستفاد من ذللك النص أن المشرع

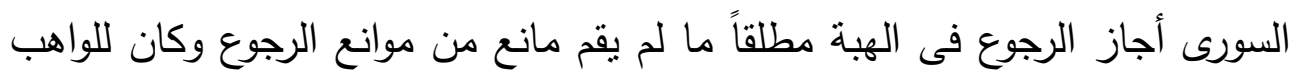

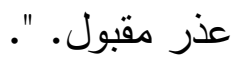

وقد نظم الرجوع فى الهبة المواد ارقام

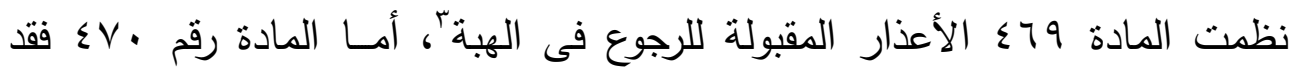
ا د. محيب الدين إسماعيل علم الدين ، أصول القانون المدني ، الجزء الثاني ، العقود المسماة ،

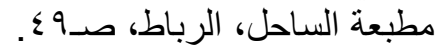

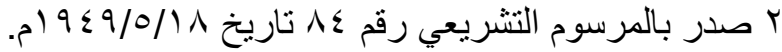

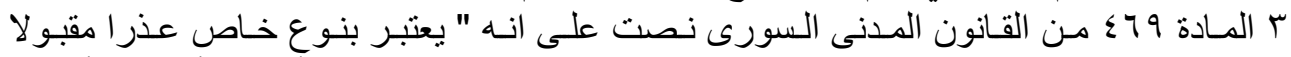

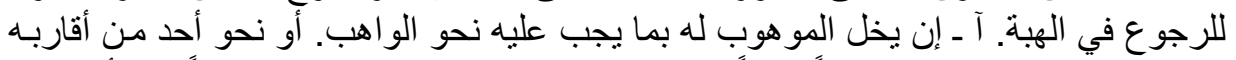

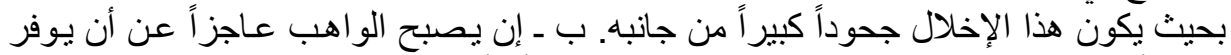

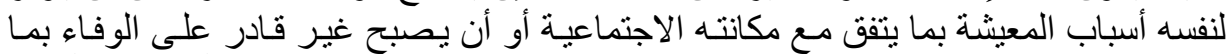

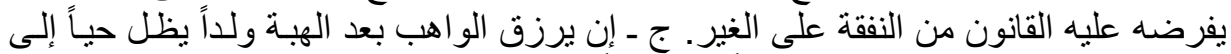
وقت الرجوع أو أن يكون الواهب ولداً يظنه ميناً وقت الهبة فإذا به حي. ". 
نظمت الموانع التى يتم رفض طلب الرجوع فى الهبة إن وجدت ' أما المادة رقم

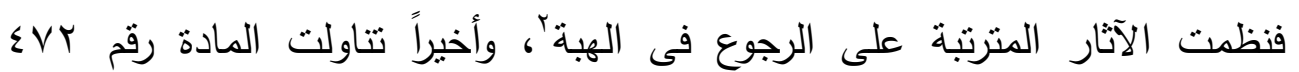
مسؤولية الواهب فى حالة استرداده الثئ الموهوب بغير التراضى أو التقاضىى' الغصن الثالث / بالنسبة للتشربع العراقي

لقد سار المشرع العراقى على نفس النهج الذى اتبعه القانون المدنى المصرى والسورى، فنص فى المادة رقم • با7 من القانون المدنى ؛ على أنه " للواهب أن يرجع فى الهبة برضاء الموهوب له، فإن لم يرضى كان للواهب حق الرجوع عند تحقق سبب مقبول، ما لم يوجد مانع من الرجوع".

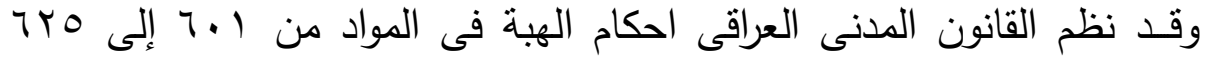
منه، وطبقاً لنص المادة عاليه رقم .r7 فإن الأصل أن يكون الرجوع فى الهبة

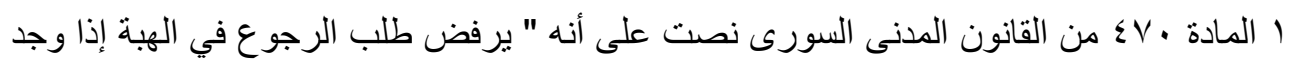

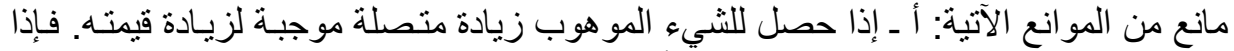

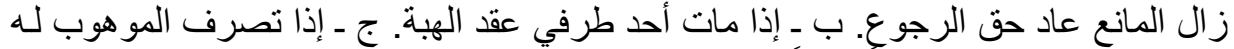

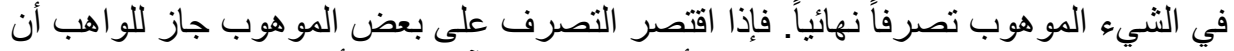

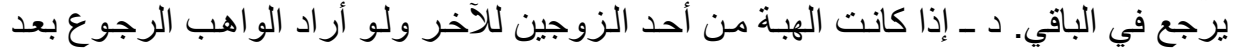

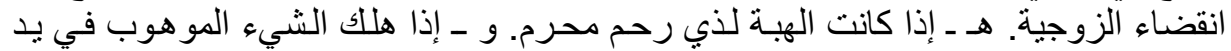

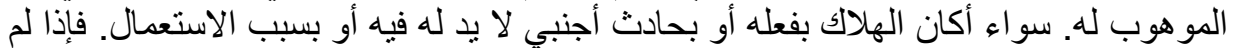

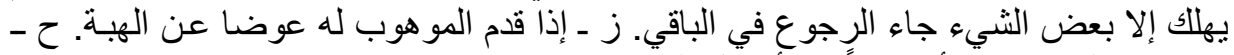

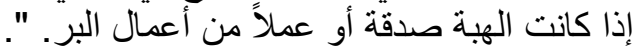

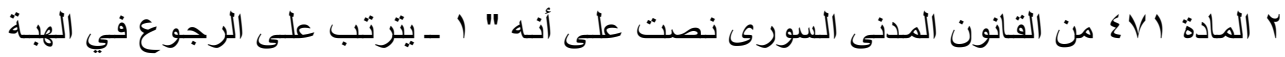

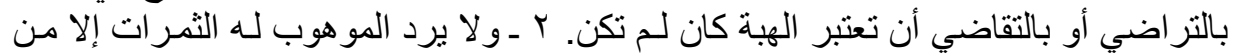

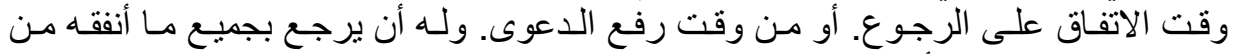

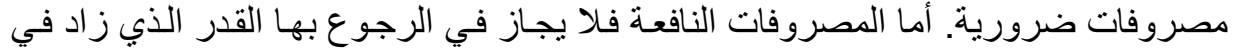

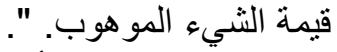

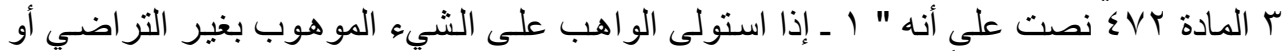

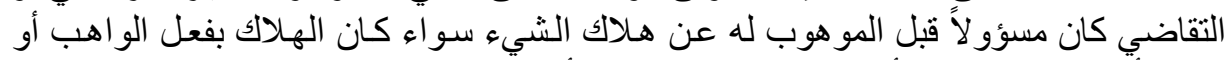

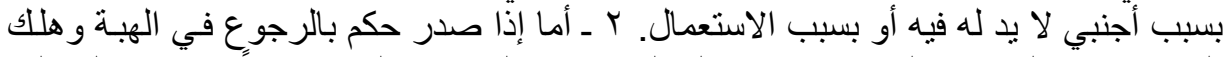

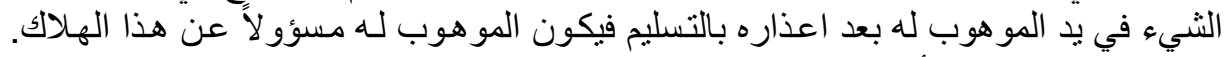

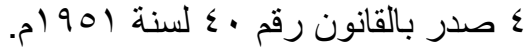


برضاء الموهوب له، فان حصل ذلك عُدَ العقد الجديد إقالة للهبة، أما إذا لم يرض الموهوب له، فليس أمام الواهب للرجوع إلا الالتجاء للقضاء، متى توفرت اعذار قانونية.

وقد نصت على تلك الأعذار المادة رقم ابT والتى جاءت على سبيل المثال

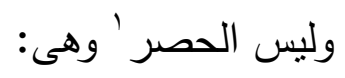

(أ)- الجحود: وقد أورد النص النتريعى لفظ "إخلالا خطيرا"؟؛ وعليه فإن نص هذه الفقرة يمكن أن يشمل أي عمل أو امتتاع عن عمل يصدر من الموهوب له ويلحق بالواهب ضرراً مادياً أو معنوياً إلى الحد الذي يكون فيه هذا السلوك إخلالاً خطيراً ويشكل في الوقت ذاته جحوداً غليظاً من جانب الموهوب له، دون أن يحصر المشرع الأفعال التي تشكل ذلك الإخلال الخطير والتي تتطوي على الجحود الغليظ، وهذا بخلاف القانون المدني الفرنسي الذي حصر هذه الأفعال لأن الأصل فيه هو عدم جواز الرجوع في الهبة، حيث ذكرت المادة ( 900 ) من القانون المدني الفرنسي حالات الجحود على سبيل الحصر وهي الاعتداء على حياة الواهب، وإساءة معاملة الواهب إساءة جسيمة أو إذا ارتكب نحوه جريمة جسيمة أو أهانه إهانة جسيمة، وأخيراً

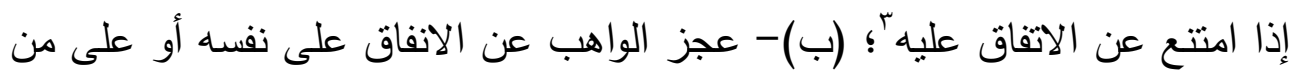

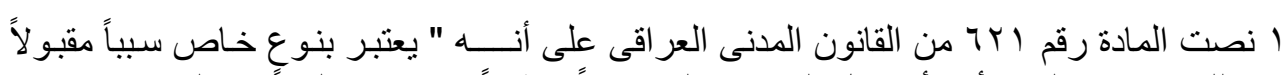

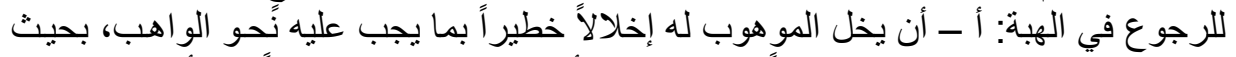

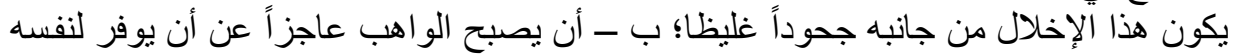

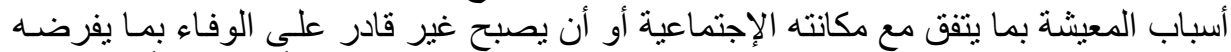

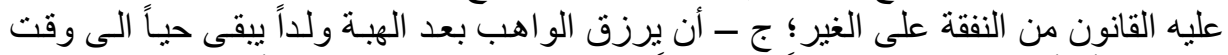

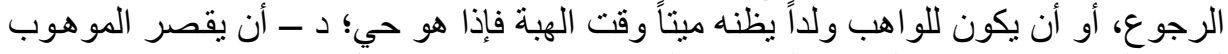

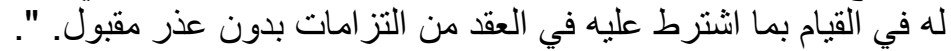

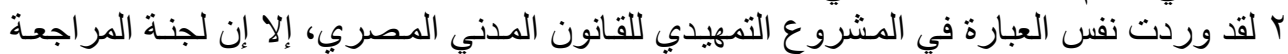

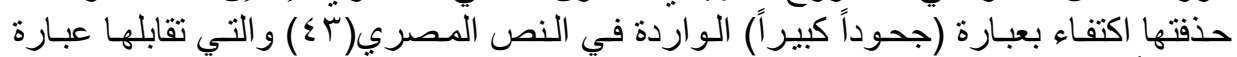

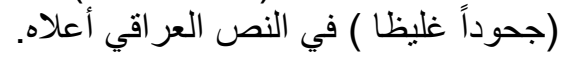

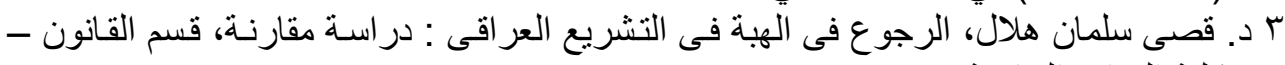

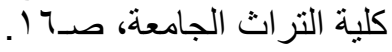


تلزمه النفقة عليه انفاقا يتفق مع مركزه الاجتماعى؛ (ج)- أن يرزق الواهب بعد الهبة

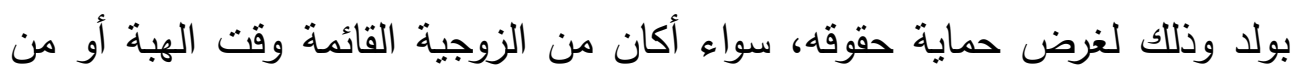
زواج لاحق؛ (د)- إخلال الموهوب له بالتزاماته العقدية، فمثلا إذا كان الواهب قد اشترط تكليفا على عاتق الموهوب له، فان عدم تتفيذ هذا الالتزام يبيح للواهب ان بطالب الموهوب له بتتفيذه، فإن رفض او نفذ باهمال فللواهب ان يفسخ الهبة طبقا للقواعد العامة فى العقود؛ (ه)- قتل الموهوب له الواهب: وهنا يحق لورثة الواهب طلب إبطال هبة مورثه بشرط أن يكون القتل قد تم عمداً، وبدون وجه حق، إنفاذا لقاعدة شرعية وهى " من يستعجل الثئ قبل اوانه عقب بحرمانه "'. الغصن الرابع / بالنسبة للتشربع اللبنانى

لقد نظم قانون الموجبات والعقود اللبنانى عقد الهبة فى المواد من ع .0 إلى rro، ولقد أجاز قانون الموجبات والعقود اللبنانى للواهب الحق فى الرجوع عن الهبة حتى بعد اتمامها مما يُشكِل خروجاً على المفاهيم العامة المطبقة لاسيما أن العقد المنشئ يمكن ابطاله، فسخه أو الغاؤه وليس الرجوع عنه بعد اتمامه.

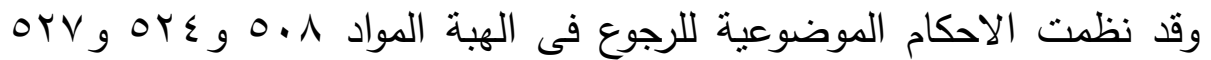
و و or، وقد نصت المادة ^ ـ0 من القانون على أنه " يبقى للواهب حق الرجوع عن العرض ما دام القبول لم يتم"، والمقصود هنا بعدم إتمام القبول هو عدم وصوله الى علم الواهب المنصوص عنه في المادة V.0. أي أنه يحق للواهب مبئياً الرجوع عن عرضه طالما لم يعلم بموافقة الموهوب لله، فمجرد قبول الموهوب له لا يلزم الواهب؟ّ.

ا المادة رقم 99 من مجلة الاحكام العدلية.

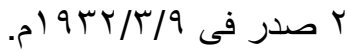
r د. غنتى مواس، إثكاليات الهبـة في القانون اللبناني، كلية الحقوق و العلوم السياسية والاداريـة

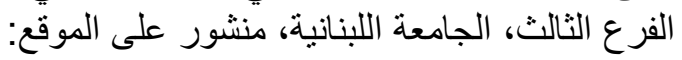
http://www.legallaw.ul.edu.Ib/ViewResearchPage.aspx?id=0 1 \&language=a $r$ 
هذا وقد نص قانون الموجبات والعقود اللبنانى على ثلاث حالات يمكن فيها للواهب الرجوع عن الهبة التامة، وهم : (أ) ظهور أولاد للواهب بعد الهبة ( المادة رقم

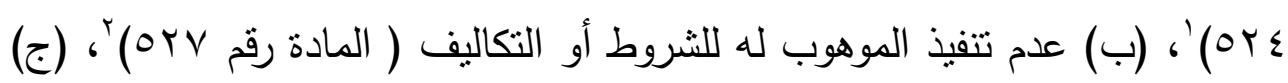

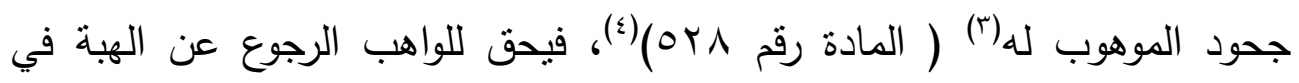
حالتين، الحالة الأولى، إذا ارتكب الموهوب له جنحة او جناية على شخص الواهب

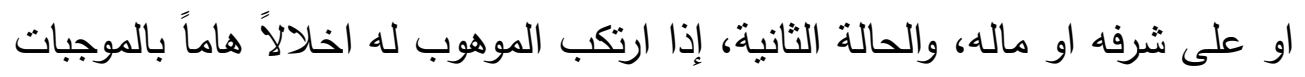
التي يفرضها عليه القانون للواهب او لعائلته.، أ-الحالة الأولى: ارتكاب الموهوب له له اله جنحة او جناية على شخص الواهب او على شرفه او ماله، وقد اعتبر بعض الفقهاء

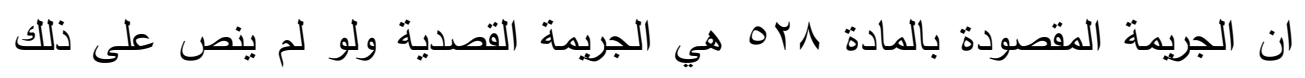
صراحةً. فبرأي هؤلاء ان القلل او الايذاء غير القصدي لا يعتبر سبياً للرجوع عن هن

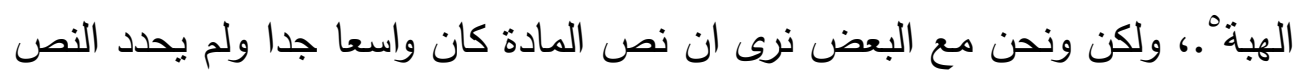
ان تكون الجريمة يجب ان تكون عمدية، بل وطبقا لتقسير النص طبقا لظاهر عباراته

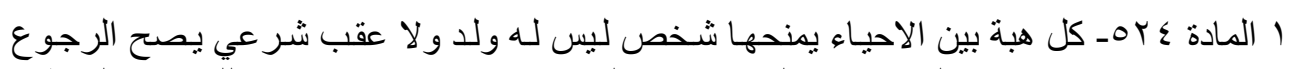

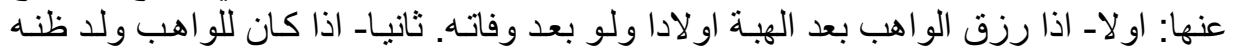

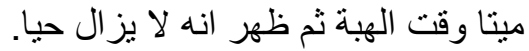

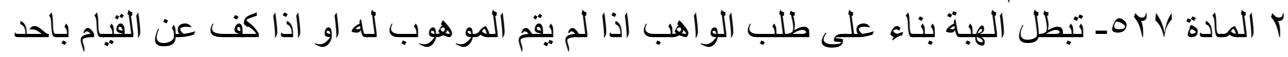

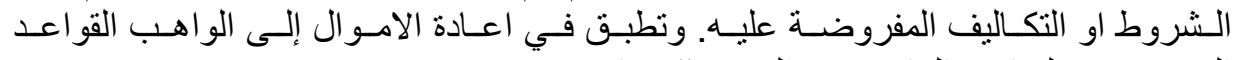

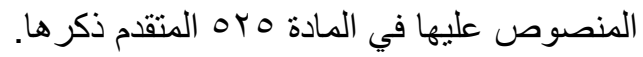

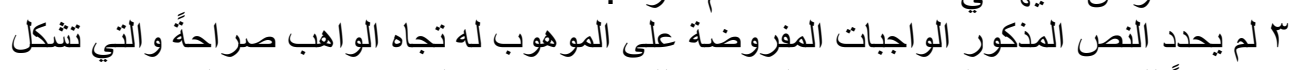

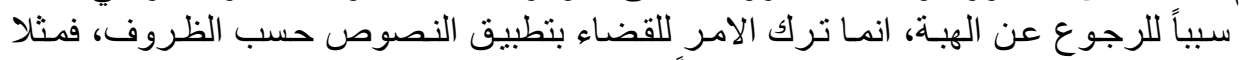

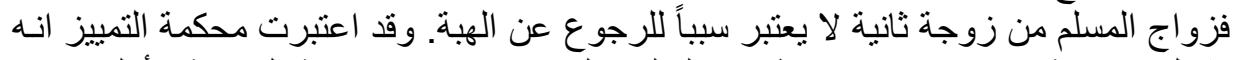

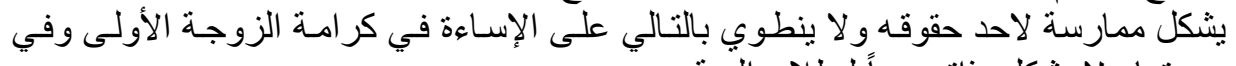
سمتتها و لا يشكل بذاته سبياً لبطلان الهئة الهبة.

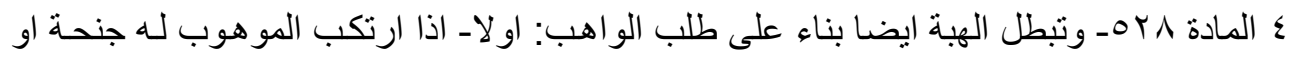

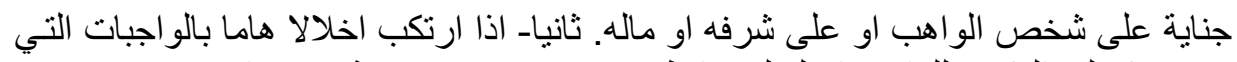

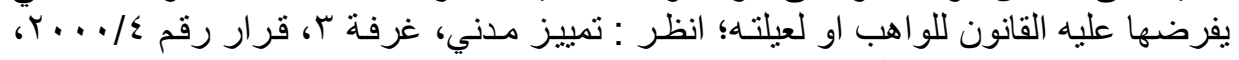

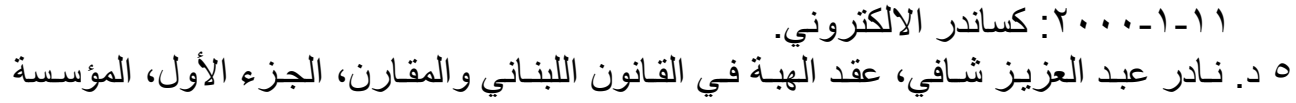

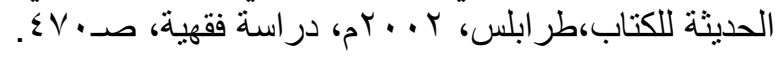


والتى لا تحمل تأويلا، فيمكن للواهب الرجوع سواء ارتكب الموهوب له جريمة عمدية او غير عمدية بشرط ان نكون جناية او جنحة، سواء على ماله او على شرفه.

ب-الحالـة الثانيـة: ارتكاب الموهوب لـه اخـلالاً هامـاً بالواجبـات التي يفرضـها عليه القانون للواهب أو لعائلته، وفى هذا الإطار فإن المحاكم المدنية اللبنانية تستتد لتعليل ارتكاب الموهوب لـه اخلالاً هاماً بالواجبات الزوجية الى القرارات الصادرة عن الصن المحاكم الروحية أو الشرعية، فقد اعتبرت محكمة التمييز المدنية اللبنانية أن صدور قرار كنسي في لبنان قضى ببطلان الزواج على مسؤولية الزوجة مؤكداً تصرفاتها العدائية والاضطهادية ضد زوجها الواهب وثثبوت عدم تحملها واجبات العائلة، يشكل جحوداً يمنح حق الواهب بالرجوع عن الهبة والمطالبة بإعلان بطلانها ('). فإذا ثبت أمام المحاكم الروحية أن الزوجة تركت منزل الزوجية ورفضت العودة

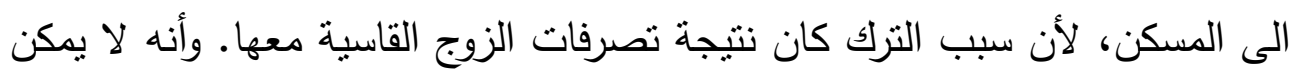
للزوج الذي تسبب بتصرفاته على إقدام زوجته إلى ترك المنزل التذرع بالجحود وفقاً

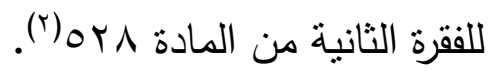

\section{الغصن الخامس / بالنسبة للتشربع الجزائرى}

لقد تتاول المشرع الجزائرى الرجوع في الهبة في قانون الأسرة وذلك في الفقرة الاولى من المادة رقم IIIا، والتى تتص على على أن " للأبوين حق الرجوع في الهبة لولدهما مهما كانت سنه ".

ولقد أخذ المشرع الجزائرى بهذا المبدأ عن المذهب المالكى والذى أجاز الرجوع فى الهبـة للوالدين فقط دون غيرهما، وعمل القضاء على تكريس هذا المبدأ، عندما

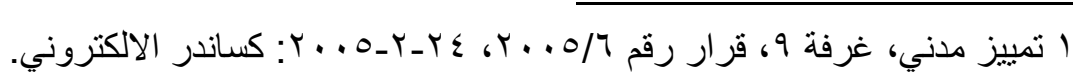

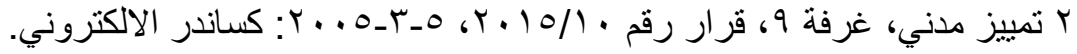


اعتبر أن المقصود بكلمة الأبوين الاب والأم فقط ولا تشمل الجد والجدة، إذ لا يحق للجدة الواهبة التراجع عن هبتها لحفيدها' .

إذن فلا يجوز الرجوع فى الهبة بارادة الواهب المنفردة إلا استثناءاً وفي حدود ما اوردته المادة || (إ من قانون الأسرة التي تقضي بأن للابوين حق الرجوع في الهبة لولدهما مهما كانت سنه الافي الحالات التالية : 1- اذا كانت الهبة لزواج الموهوب له.، r - اذا كانت الهبة لضمان قرض اوقضاء دين.، ب- اذا تصرف الموهوب لله في الثيء الموهوب بيعه أو تبرع به أو أدخل عليه ما غير طبيعته.

والهدف من وضـع المشرع لهذا الاستثناء هو حماية للوالدين، وتوفير ضمانات خاصة لهم من الأضرار التي تلحقهم من جراء تبذير أموالهم من طرف أولادهم، نظراً لتغيير الظـروف التي تمـت فيها هذه الهبـة، ومـا يطرأ مـن أوضـاع بعد ابـرام هذا

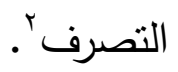

وقد جاءت المادة Y ا Y بمنع الرجوع في الهبة اذا كانت بقصد المنفعة العامـة ، تاكيدا للزوم عقد الهبة ولمبدا عدم اللاجوع في الهبة في غير الحالات المستثاة وهذا المبدا جاء اقرارا وجريا على مبدا عدم الرجوع عند جمهور الفقهاء ، وهم المالكية ، الشافعية والحنابلة ماعدا الحنفية فالجمهور يرى المنع ، اما الحنفية فالاصل عندهم الحق للواهب في الرجوع عن هبته ، فهي عقد غير لازم ويستندون في ذلك الى

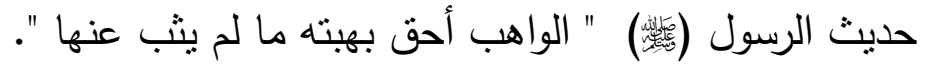
وهذا ما ذهبت إليه المذكرة الصادرة عن المديريـة العامة للأمـلاك الوطنية رقم

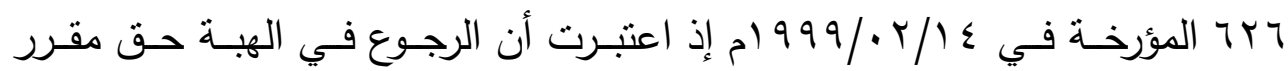
للوالدين فقط على وجه الإستثناء الذين أقدموا على إبرام هذا التصرف لصالح أبنائهم 1 فريدة هلال، الهبة فى ضوء القانون و القضاء الجزائرى، رسالة ماجستير، كلية الحقوق، جامعة

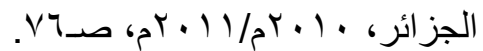

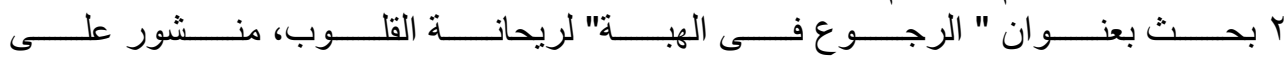
http://www.startimes.com/?t=r $r q r \leqslant r \cdot \tau$ 
دون اللجوء إلى القضاء إذ يكفي التصريح بالرجوع أمام الموثق وبالإرادة المنفردة لأحد الوالدين بمعنى أن الموثق ملزم بتحرير عقد الرجوع في الهبة اذا التمس منه الوالدين ذللك، ويتم بموجب استرجاع الواهب لأملاكه، حيث يتم إلغاء الحق بنفس الثكل الذي نشأ بـه'.

ولقد عززت المحكمة العليا الجزائريـة هذا المبدأ المتمثنل بـأن حق الرجوع في الهبة هو حق مقرر للأبوين فقط'، وهذا عندما ذهبت إلى نقض القرار المطعون فيه الذي قضى بصحة جواز العدول في الهبة للجدة معلاً ذلك اجتهاد خاطئ في تفسير للمادة وهذا لما اعتبر الجدة بمثابة الأمّّ. وقد أبرزت المحكمة العليت في كل قراراتها

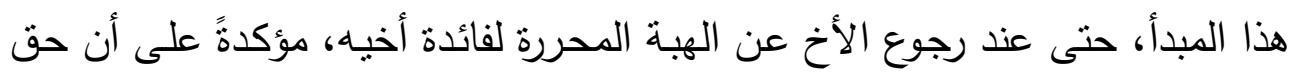
الرجوع مكرس للأبوين لا غير وهذا عندما قضت بنقض وابطال القرار المطعون الذي قضى التصربح بتقرير رجوع المدعي على عقد الهبة الذي أبرمه لفائدة المدعي عليه، ومن ثم إلغاء عقد الهبة الذي يربط المتعاقدين مؤسسة نقضها على علاقة الأخوة لا تمنح للواهب أن يرجع في هبته لان هذا الحق كما هو معلوم عن المذاهب الثلاثة

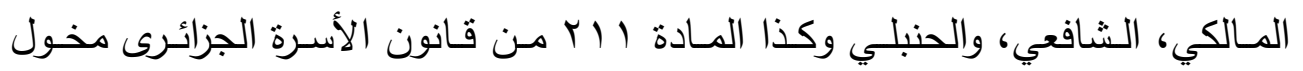
للأبوين فقط؛

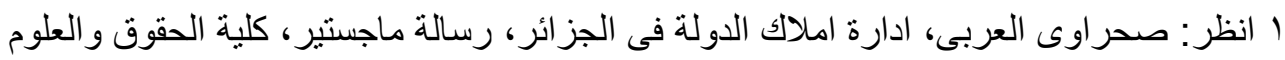

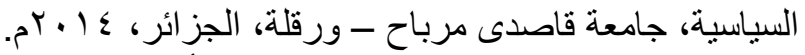

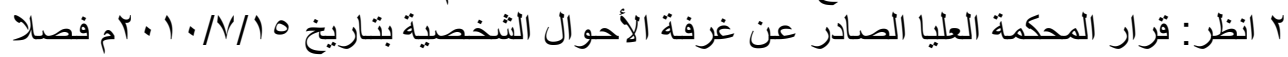

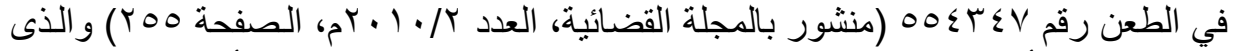

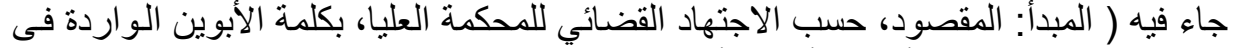

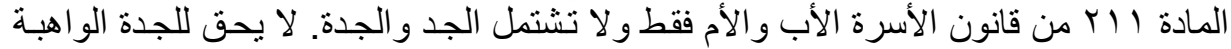

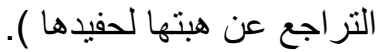

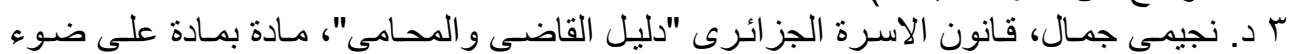

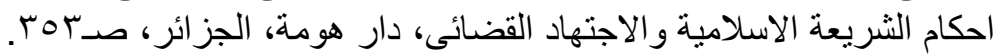

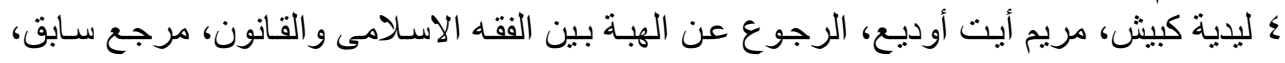




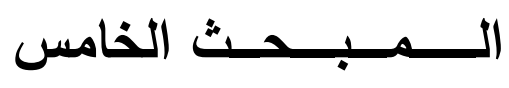

\section{آثار الرجوع فى الـهـبــة}

\section{تمهي⿻ وتقسيم:}

إن الرجوع فى الهبة تقايل، إذا تم بالتراضى، وفسخ اذا تم بالتقاضى، وسواء كان تقايلا او فسخا، فان الرجوع يرتب مجموعة من الآثار فى حق المتعاقدين من جهة، وفى حق الغير من جهة أخرى، وسوف نقسم هذا المبحث إلى مطلبين، حيث سيكون المطلب الأول عن آثار الرجوع فى الهبة فى الفقه الإسلامى، في حين سيكون المطلب الثانى عن آثار الرجوع فى الهبة فى القوانين الوضعية. المطلب الأول

آثار الرجوع فى الهبة فى الفقه الإسلامى

$$
\text { تمهيد وتقسيم: }
$$

لبيان وتحديد آثار الرجوع عن الهبة فى الفقه الإسلامى، فيجب علينا تتاول ذلك من خـلال فرعين، حيث سيكون الفرع الاول عن آثار الرجوع فى الهبـة فيمـا بين المتعاقدين، اما الفرع الثانى فسوف يكون عن آثار الرجوع فى الهبة بالنسبة للغير ، وذلك على النحو التالى.

\section{الــــــــــع الأول}

آثار الرجوع فى الهبة فيما بين المتعاقدين

فى حالة هـلاك الشئ الموهوب، فـان الفقه الاسـلامى يعتبر الواهب فى هذه الحالـة غاصبا، وهو ضـامن لقيمـة الشئ إذا هلك، وفى هذه الصورة ليس للواهب 
الرجوع فى الهبة، وعليه أن يضمن للموهوب له بدله أو قيمته إذا كانت من القيميات،

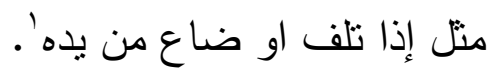

وهنـاك ثلاثنة آثار تترتب فيمـا بـين المتعاقدين، وسـوف نتــاولهم على النحـو التالى، كلّ فى غصن. الغصن الأول/ إلزام الموهوب له برد الثئ الموهوب

إن أثر الرجوع الرئيس هو إرجاع المتعاقدين إلى الحالة التى كانا عليها قبل

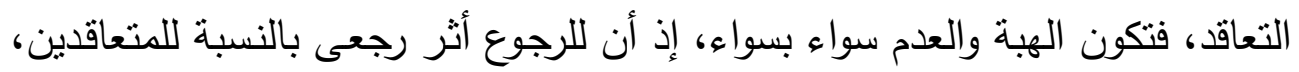

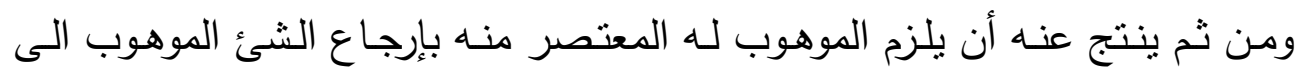
الواهب، وذلك بتسليمه إيـاه، ويقوم مقام التسليم شـهر سـند الرجوع فـى المحافظـة العقارية، هذا إن كان الثئ الموهوب عقاراً . إذن فإن الرجوع فى الهبة يرتب فسخها واعتبارها كأن لم تكن، إذ يرد الواهب الشـئ الموهـوب، ولـو لـــ يقبضها، وهـذا مـا ذهـب اليـه الفقهـاء المالكيـة والـشافعية والحنابلـة، وقـد وافـق جمهور الحنفيـة ذلك ان تـم الرجـوع بالتقاضـى، أمـا اذا كـان بالتراضى فاختلفوا فى ذلك وسبب هذا الخلاف هو هل الرجوع بالتراضى هو نقض للعقد من اصله، اما اتفاق على انشاء عقد جديدّ. أما فى حالة المنقول فإن إلزام المعتصر منه بتسليم الثئ الموهوب، يكون بكل الطرق المتاحة للوفاء بالالتزامـات، من التنفيذ العينى، الى التنفيذ بمقابل، وإن هلك

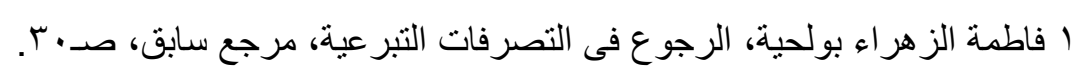

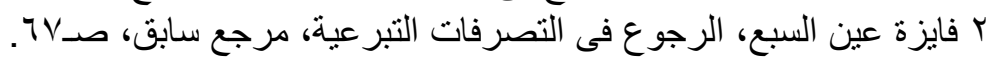

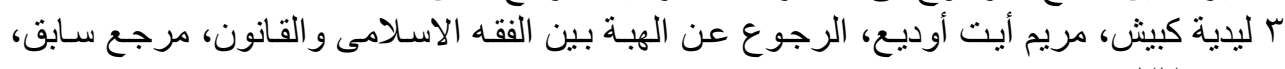


الثئ الموهوب فى يد الموهوب لـه بعد تاريخ رفع دعوى استرداد المنقول المعتصر ، فإن الهلاك يقع فى ضمان الموهوب لله المعتصر منه وعلى مسؤوليته' .

\section{الغصن الثانى/ إلزام الموهوب لله برد الثمار}

تعتبر ثمار الشئ الموهوب ملكاً للموهوب لله إلى غايـة اليوم الذى يرجع فيـه

الواهب عن هبته بموجب سند الرجوع، او من يوم رفع دعوى استرداد الشئ الموهوب إن كان منقولا، إذ جاء فى كتاب الفقه على المذاهب الاربعـة للجزبرى ما مفاده ان الزيادة المنفصلة - والمقصود بها الثـار - هى ملك للولد الموهوب له لأنها حدثت قبل الرجوع، وهذا رأى الجمهور '

وذهب البعض من الفقه إلى أنه يجب التفرقة فى هذا الشأن بين ما اذا كانت الزيادة منفصلة، او متصلة، ففى الزيادة المنفصلة، اتفق الفقهاء على أن الثمار سواء كانــت متولـدة كـالثمرة او اللـبن يعـد الحليـب، او غيـر منولـدة كالغلـة، فهنـا الثــار للموهوب له لا حق له للواهب فيها؟.

أمـا اذا كانـت الثمـار متصلة، فهنـاك اختلاف بـين الفقهـاء، فقهـاء المالكيـة، الحنفية، والحنابلة ذهبوا إلى أنها للموهوب له، إذا كان يمنع على الواهب الرجوع فيه هذا تبعا للاصل، أما فى حالة جواز الرجوع تبعا للاصل ایى الثـئ الموهوب والثمرة ملكها للواهب لا تمنع فيها الرجوع فهى اذن للواهب تبعا للاصل، أما الشافعية فذهبوا الى ان هذه الثمار من حق الواهب؛

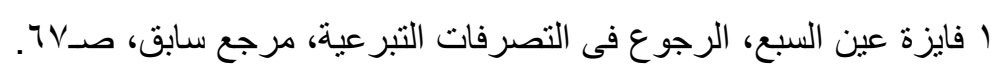

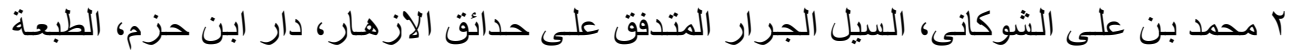

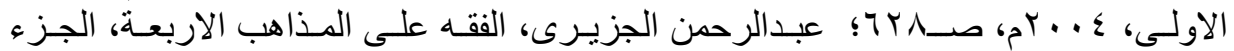

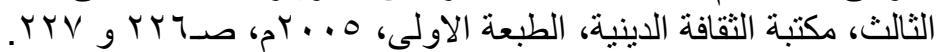

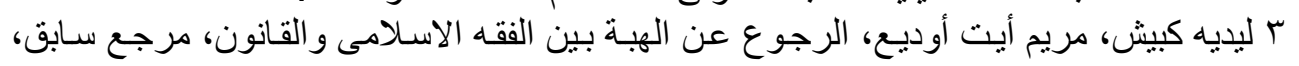

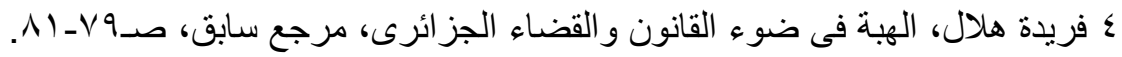




\section{الغصن الثالث/ رجوع الموهوب له بالمصروفات على الواهب}

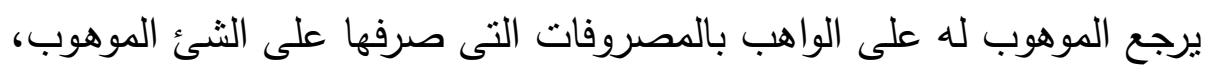

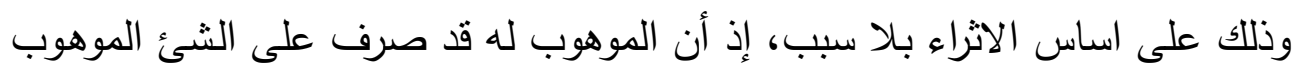

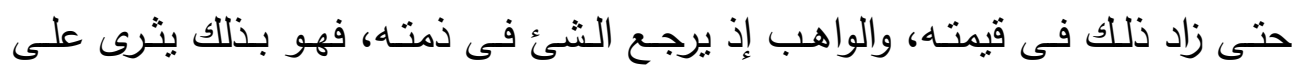

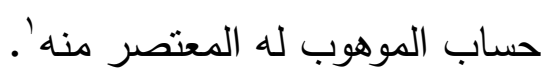

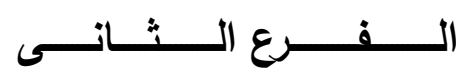

\section{آثار الرجوع فى الهبة بالنسبة للغير}

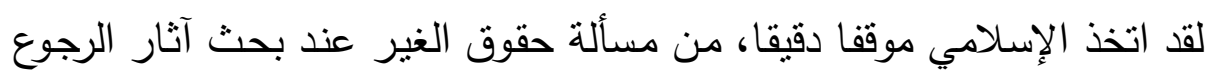

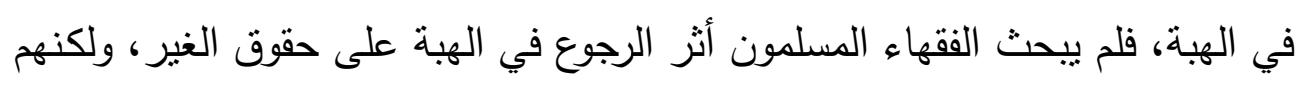

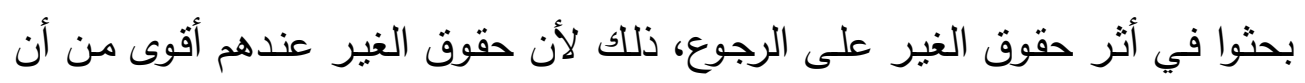

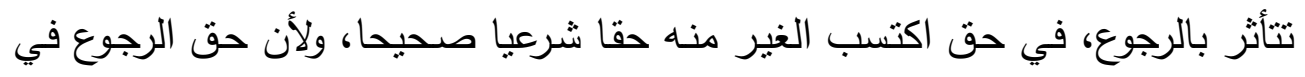

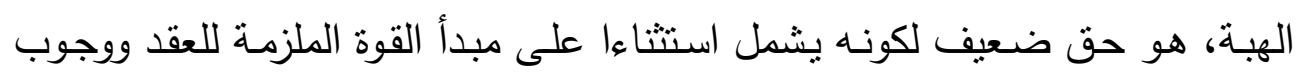

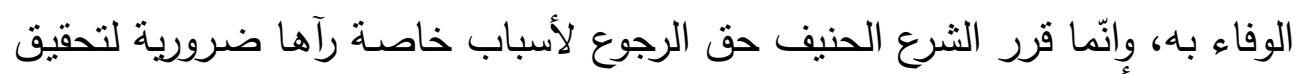

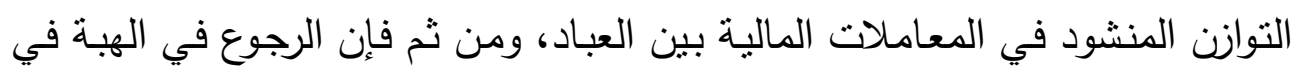

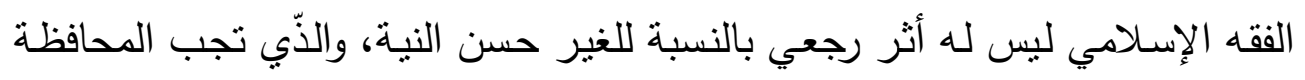

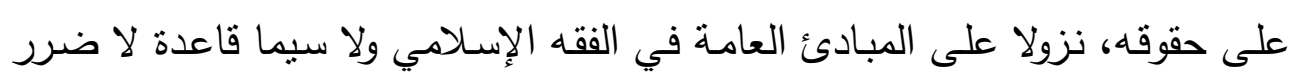

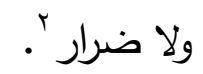

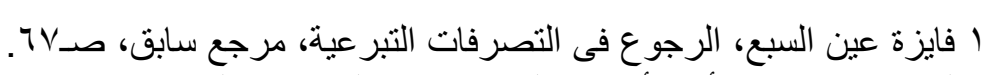
r ليديه كبيش، مريم أيت أوديع، الرجوع عن الهروات لهبة بين الفقه الاسلامى و القانون، مرجع سابق، 


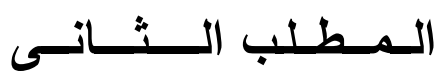

\section{آتثــــار الرجوع فى القوانين الوضعية}

تمهيد وتقسيم:

لبيان وتحديد آثار الرجوع عن الهبة فى القوانين الوضعية، فيجب علينا تتاول ذلك من خلال عدة فروع، حيث سيكون الفرع الأول عن آثار الرجوع فى الهبة فى القانون المصرى، أما الفرع الثانى فسوف نخصصة لآثار الرجوع فى القانون العراقى، فى حين سنخصص الفرع الثالث للقانون الجزائرى، وذلك على النحو التالى.

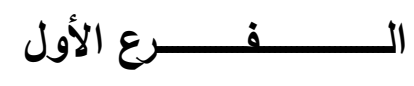

آثار الرجوع فى الهبة فى القانون المصرى

الرجوع فى الهبة تقايل، إذا تم بالتراضس، وفسخ إذا تم بالتقاضى، وسواء كان

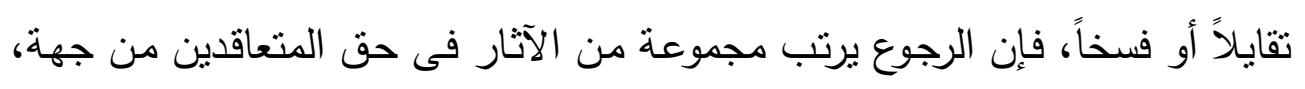
وفى حق الغير من جهة أخرى، وسوف نقسم هذا الفرع الى غصنين، بحيث نخصص الغصن الأول للكلام عن آثار الرجوع بين المتعاقدين، أما الغصن الثانى فسوف يكون عن أثر الرجوع فى حق الغير، وذلك على النحو التالى. الغصن الأول/أثز الرجوع فى الهبة بين المتعاقدين

رجوع الواهب فى القانون المصرى قضاءً أو رضاءً يترتب عليه نفس الأثر وهو انفساخ الهبة بأثز رجعى بحيث تعتبر الهبة كأن لم تكن، وعلى ذلك نصت المادة رقم r/1/ من القانون المدنى المصرى والتى جاء نصها " يترتب على الرجوع فى الهبة بالتراضى، إذ تتفسخ بأثر رجعى وتعتبر الهبة كأن لم تكن "، وهذه المادة تقابل المادة

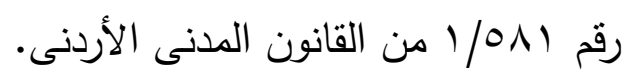


ولكـن قبل الرجوع فـى الهبة بالتراضـى أو بالقضاء فإن الهبة تكون قائمـة، فلا يستطيع الواهب أن يمتتع عن تسليم الشئ الموهوب إذا لم يسلمه، ولا يستطيع أن يسترده إن كان قد سلمه، فإن أقدم على استرداده بعد أن كان قد سلمه بغير تراض أو

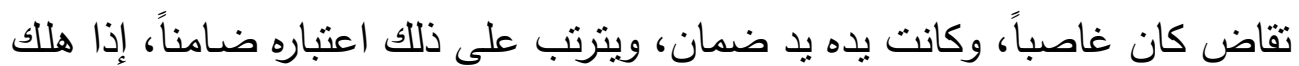
الثـئ فى يده، ووجب أن بدفع للموجب له قيمة الثئ وقت الهلاكى ('). وهنـاك مجموعة من الآثار التى تترتب على الرجوع فى الهبة بين المتعاقدين

(أ) رد الموهوب له: فطبقا للبند الثانى من المادة ؟ ــ فهناك إلزام قانونى على الموهوب لله أن يرد الشئ الموهوب إن كان قائمـا بعد الرجوع فـى الهبـة سواء أكان الرجوع اتقاقا او قضاءً، فاذا امتتع الموهوب لله عن الرد وقام الواهب بإعذاره تسليم الموهوب، فإن لم يفعل فإن الموهوب له يكون ضـامنا ومتحملا تبعية هلاك الموهوب ولو كان الهلاك بسبب أجنبى' . (ب) رجوع الموهوب بالثمرات: الثمار هى الزبادة الحادثة فى الشئ الموهوب بعد القبض، وتتقسم هذه الزيادة الى قسمين، الاولى الزيادة المتصلة بالشئ الموهوب لا يمكن قطعها، والثانية الزيادة المنفصلة عن الثئ الموهوب يمكن قطعها دون ضرر

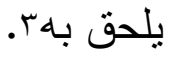

(ج) رجـوع الموهـوب لــه بالمـصروفات: نـص القـانون المــنى علـى هـــه المصروفات فى المادة رقم r/0/ r/ والتى جاء نصها " ..... وله أن يرجع بجميع ما ا د. عبدالرازق السنهورى، الوسيط فى شرح القانون المدنى الجديد،الجزء السادس، الطبعة الثالثة،

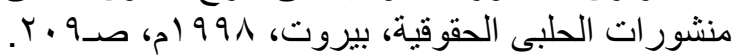
ب د. جمال الدين طه العاقل، عقد الهبـة بين الفقه الإسـلامى و القانون المدنى، دار الهـى، مصر،

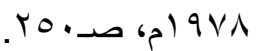
ب د. حسن محمد بودى، موانع الرجوع في الهبة "في الفقه الإسـلامي والقانون الوضعي"، مرجع

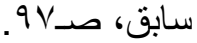


أنفقه من مصروفات ضرورية، أما المصروفات النافعة فلا يجوز الرجوع بنفس القدر

$$
\text { الذى زاد فى قيمة الثئ الموهوب". }
$$

الغصن الثانى/ أثز الرجوع فى الهبة بالنسبة للغير

قد يقوم الموهوب له بييع الثئ الموهوب لله او ترتيب حق عينى او شخصى عليه كحق ايجار، او انتفاع او رهن، او غير ذلك من الحقوق، وبالتالى فان فيام الواهب بالرجوع فى الهبة يصطلم مع الغير الذى ترتب له حقوق قبل الثئ الموهوب، مما يستبع دراسة آثار الرجوع بالنسبة لهؤلاء الغير ، وهنا يجب أن نفرق بين حالتين، على النحو النالى. - ملى

\section{أولاً: حالة قيام الموهوب له بالتصرف فيى الثئ الموهوب تصرفاً نهائياً}

وقد نظمت هذه الحالة المـادة رقم • V ع والتى نصت على أنه " يُرفَض طلب الرجـوع في الهبـة إذا وُجِدَ مـانع مـن الموانـع الآتبـة: أ-....... ب- ..... ج - إذا تصرف الموهوب له في الثيء الموهوب تصرفاً نهائياً، فإذا اقتصر التصرف على بعض الموهوب جاز للواهب أن يرجع في الباقي.....".

\section{ثنانياً: حالة قيام الموهوب له بترتيب حق عينى على الثئ الموهوب فقط}

قد يرتب الموهوب له حق عينى للغير على الثئ الموهوب كحق انتفاع أو حق إرتفاق أو حق رهن، فهنا فى هذه الحالة تُطبَق القواعد العامـة، ويجب أن نُفرِق بين

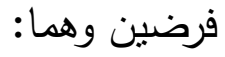

( ) إذا كان الثئ الموهوب عقاراً، بعد تسجيل صحيفة الرجوع فى الهبة أو بعد تسجيل التراضى على الرجوع فى الهبة، فإن حق الغير لا يسرى بالنسبة إلى الواهب، ويسترد الواهب الثئ الموهوب غالباً من حق الغير، ويعود هذا الغير على الموهوب له طبقاً للقواعد العامة، لكن إذا كان حق الغير قد ترتب فإن تسجيل صحيفة دعوى 
الرجوع أو التراضى عن الرجوع فى الهبة إذا كان حسن النية قيام عذر مقبول يسرى حقه بالنسبة للواهب أما إذا كان سئ النية فحقه لا يرى بالنسبة للواهب' .

r) إذا كان الثـئ الموهوب منقول، والرجوع بالتراضى فى هذه الحالة الرجوع لا يؤثز فى حقوق الغير، إما إذا كان بالتقاضى فان فسخ الهبة يحكم القضاء يكون له اثر رجعى حتى بالنسبة للغير، فيسترد الواهب المنقول خاليا من حقوق الغير، اذا كان الغير حـاز حقهه وهـو حسن النيـة، بـأن كـان لـه حق انتفـاع، او رهـن حيازة منقول للانتفاع به او يرتهنه وهو حسن النية، فهنا الحيازة فى المنقول تعد سندا لحق الغير فالواهب لا يستطيع أن يسترد المنقول إلا منقلا بهذا الحق.

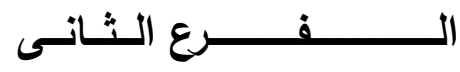

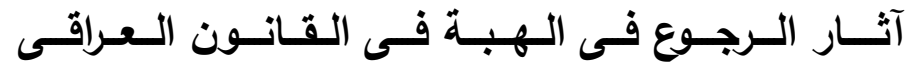

نظمت المـادة رقم ع ب7 من القانون المدنى العراقى آثار الرجوع حيث نصت على أنه " ا- إذا رجع الواهب في هبته بالتراضي أو بالتقاضي كان رجوعه إبطالاً لأثز العقد من حين الرجوع، وإعادة لملكه؛ ب - ولا يرد الموهوب لـه الثمرات إلا من وقت الإتفاق على الرجوع أو من وقت رفع الدعوى، وله أن يرجع بجميع ما أنفقه من المصروفات الإضطرارية، أمـا المصروفات النافعة فـلا يجاوز في الرجوع بها القدر الذي زاد في قيمة الموهوب. ".

ويُسنَفَاد من النص عاليه، أنه فى حالة الرجوع بالتراضى أو عن طريق القضاء برفع دعوى أو مطالبة بفسخ عقد الهبة، فإنه بالإتفاق أو بالحكم على الرجوع فى الهبة يرجع الطرفان إلى الحالة التى كانا عليها قبل العقد، أى يكون بأثز رجعى. ا مريم أيت أوديع، الرجوع عن الهبة بين الفقه الاسلامى والقانون، مرجع سابق، صـ9 V. 
ولكن بالنسبة للثـرات التى حصل عليها أو استفاد منها الموهوب لله، فإنه لا

يُطالِب بها إلا من وقت الإتفاق على الرجوع أو من وقت رفع الدعوى أو المطالبة أمام القضاء.

كذلك فإن الموهوب لـه يمكن لـه أن يرجع ويطالب الواهب بكل المصروفات الإضطرارية التى أنفقها على الثئ الموهوب محل عقد الهبة، أما المصروفات النافعة للموهوب له أن بطالب بها الواهب بالقدر الذى زاد فى قيمة الثئ الموهوب، أما إذا لم تظهر ثمة زيادة فى قيمة الثئ الموهوب فلا يحق للموهوب له المطالبة بما أنفقه من مصروفات نافعة.

والجدير بالذكر أن المـادة هب7 منعـت الواهب مـن أخذ الشئ الموهوب مـن الموهوب له قبل التراضـى والإتفاق بينه وبين الموهوب لله، أو قبل الحكم بفسخ عقد

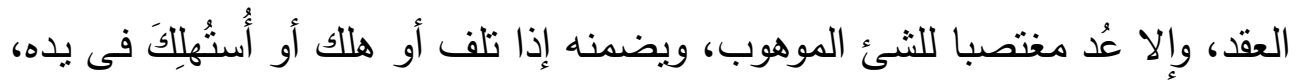
وللموهوب له أن يطالب بقيمة الثئ فى هذه الحالة.

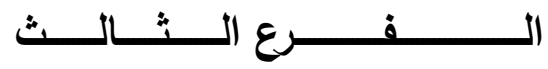

آتثـار الـرجـوع فى الـهبـة فـى الـقـــــون الـــزائـرى

هناك نوعين من الآثار فى هذا الشأن، وهما فيما بين المتعاقدين، وبالنسبة للغير ، وسوف نتتاولهما على النحو التالى، على مدار غصنين. الغصن الأول/ آثار الرجوع فى الهبة بين المتعاقدين

يترتب على الرجوع فى الهبة كما هو الثأن فى القانون المصرى وهو اعتبارها كأن لم تكن، وبذللك للواهب ان يسترد الثئ الموهوب من الموهوب له، حيث نصت

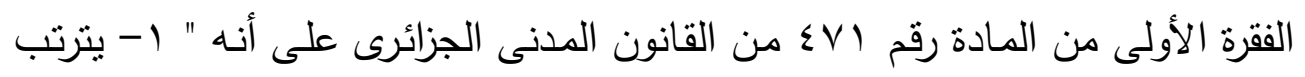
على الرجوع فى الهبة بالتراضى او بالتقاضى أن تعنبر الهبة كأن لم تكن "، وبالتالى فان للواهب أن يسترد الثئ الموهوب، سواء كان عقارا او منقولا. 
ولكن اذا هلك الشئ الموهوب، فهنا نفرق بين فرضين، الفرض الأول هو اذا كان الهالك بسبب الموهوب له، فيحق للواهب ان يعوض بما لحقه من ضرر باعتبار الموهوب له كان ضمانا لهذا الهلاك لميعاد وموعد التسليم، أما الفرض الثانى اذا كان الهلاك بسبب اجنبى ولا يد للموهوب له فيه، فتبعية الهالك يتحملها الواهب، باستثناء اذا قام الواهب باعذار الموهوب له بالتسليم، وهذا الموهوب له يتحمل تبعية الهلاك

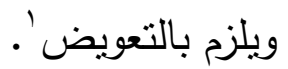

وللموهوب لـه أن يرجـع على الواهب بمـا أنفقه مـن المصروفات على الشيء الموهوب، وهذا ما نصت عليه الفقرة الثانية من المادة عاليه والتى نصت على أنه " r ـ ولا يرد الموهوب له الثمرات إلا من وقت الاتفاق على الرجوع. أو من وقت رفع الدعوى. ولـه أن يرجـع بجميع مـا أنفقه مـن مصروفات ضـرورية. أمـا المصروفات النافعة فلا يجاز في الرجوع بها القدر الذي زاد في قيمة الثيء الموهوب.". هذا وقد نـص المشرع الجزائرى فى القـانون المـنى على المـصروفات النافعـة فى

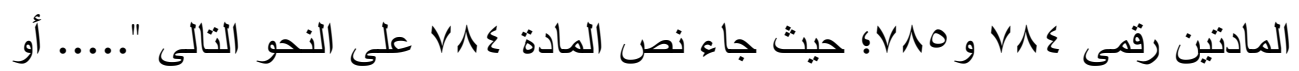
أن يطلب استبقاءها مقابل دفع قيمتها او قيمتها فى حالة الهدم او دفع مبلغ بساوى ما زاد فى ثمن الارض بسبب وجود المنشآت بها". فى حين جاء نص المادة V^0 " ..... فليس لصاحب الأرض أن بطلب الإزالة وإنما يخير بين أن يدفع قيمة المواد وأجرة العمل او مبلغا يساوى ما زاد فى قيمـة الارض آله بسبب هذه المنشآت هذا ما لم يطلب صاحب المنشآت نزعها". أما إذا كانت المصروفات كمالية فليس يحق أن يرجع الموهوب له بشيء على الواهب ولكن يجوز له أن ينتزع من الثيء الواهب ما أحدثه من منشآت بشرط أن يرد الثيء

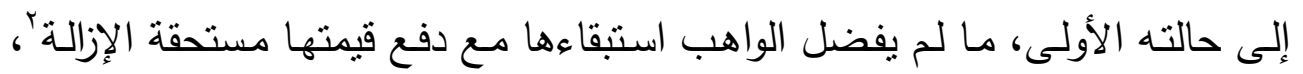




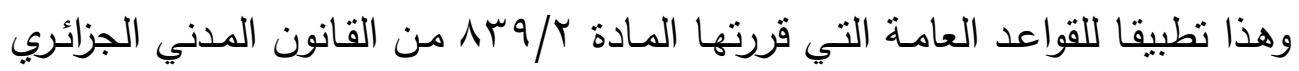
التي تتص "وإذا كانت المصروفات كمالية فليس للحائز أن يطلب بشيء منها غير أنه يجوز لله أن بزيل مـا أحدثه مـن منشآت بشرط أن يرد الشيء بحالته الولى ؛إلإ إذا

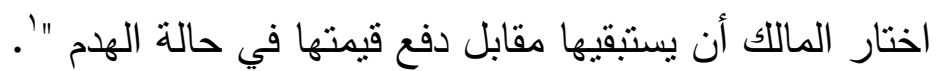
الغصن الثانى/ آثار الرجوع فى الهبة بين المتعاقدين

بدايـة فان الرجوع بالنسبة للغير ليس لله اثر رجعى، إذ تجب حمايته اذا كان

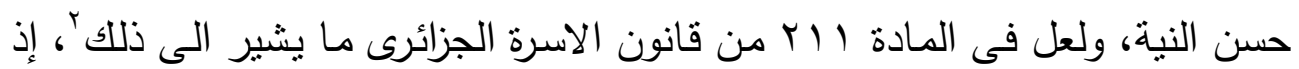
تتص الفقرة الثالثة منها على أنه "...... إذا تصرف الموهوب له فى الثئ الموهوب ببيع أو تبرع، أو ضاع منه، أو أدخل عليه ما غير طبيعته"، ولتبيان آثار الرجوع فى إلى الهبـة بين المتعاقدين، فيجب أن نفرق بين فرضين أو احتمـالين، الفرض الاول هو حالة تصرف الموهوب له فى محل الهبة تصرفاً نهائياً ناقلا للملكية، والفرض الثانى هو حالة ترتيب حق عينى كالرهن او الارتفاق على الثىئ الموهوب. أولاً: تصرف الموهوب له فى الثئ محل الهبة تصرفاً نهائياً

إذا تصرف الموهوب له فى الثـئ محل الهبة قبل الرجوع، فإن تصرفه صحيح، وليس للرجوع أى أثر قانونى بالنسبة للغير ، سواء كان الثئ عقاراً أو منقولاً، أما اذا تصرف الموهوب لـه في الشئ محل الهبـة بعد شـهر صحيفة دعوى الرجوع، فـان التصرف الذى تم للغير لا يسرى فى حق الواهب. امـا اذا كان الشئ محل الهبـة منقولا، وكان الرجوع بالتراضـى، فان الرجوع لا يؤثر فى حقوق الغير، ولا يسترد الواهب المنقول منقلا بهذه الحقوق، أمسا اذا كان الرجوع بالتقاضـى فالفسخ بموجب حكم قضائى يكون بـأثز رجعى بالنسبة للغير ،

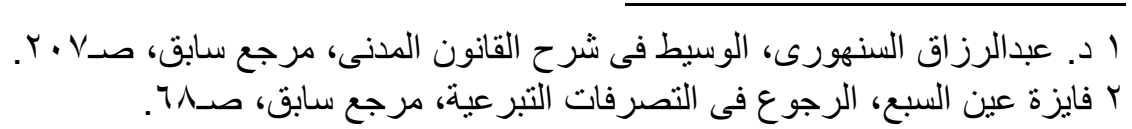


فيسترد الواهب المنقول خاليا عن هذه الحقوق، ما لم يكن هذا الغير حازه بسوء نية، ففى هذه الحالة يسترد المنقول منقلا بهذه الحقوق' .

\section{ثانياً: ترتيب الموهوب له على الثئ محل الهبة حق عينى}

وهنا يجب علينا التقريق بين حالتين، الحالـة الاولى: حالـة ترتيب حق عينى على الغير قبل شهر عريضة دعوى الرجوع او عقد التراضى على الرجوع، وفى هذه الحالـة فان حـق الغير يترتب قبل الواهب، حيث يسترد الواهب العقار ولكن مثقل بالحق العينى المترتب للغير ، ولا يحق للواهب هنا الرجوع بالتعويض على الموهوب له، إما اذا ثبت ان الغير سيئ النيةّ فان هذا الحق لا يرد فى مواجهة الواهب الذى لهى

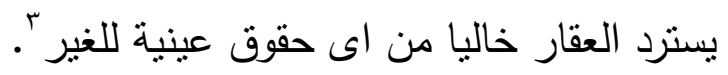

أمسا فى حالـة ترتيب حق عينى على الغير بعد شـهر دعوى الرجوع أو عقد الرجوع بالتراضى، فإن حق الغير فى هذه الحالة لا يسرى فى مواجهة الواهب، الذى لهى

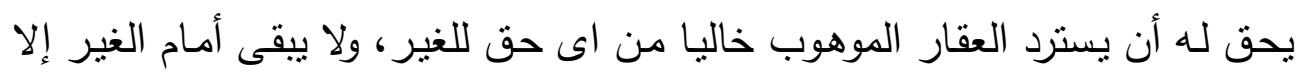
الرجوع بالتعوبض على الموهوب له طبقا للقواعد العامة؛.

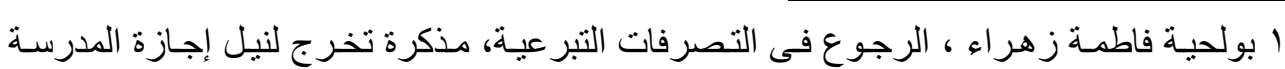

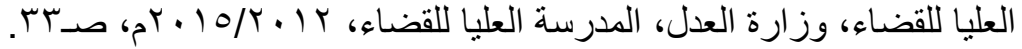

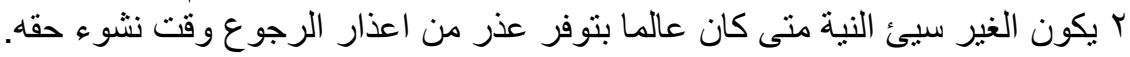

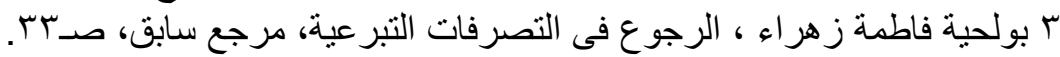

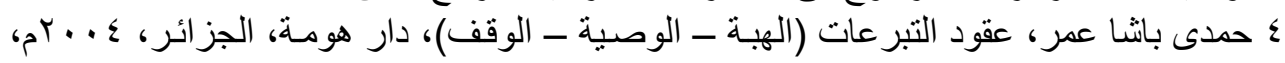




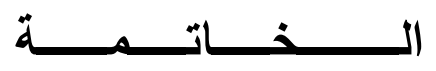

عقد الهبة من التصرفات التبرعية، وقد اهتم الفقه الاسـلامى والقانون الوضعى بتتظيمه، وخاصة فيما يتعلق بالرجوع فى الهبة، وقد أجازت الثربعة والقانون الرجوع فى الهبة، وإن اختلفت فى نطاق وحالات الرجوع، والسند الشرعى والقانونى للرجوع، وكذللك الآثار التى تترتب على الرجوع.

وقـــ تطـرق البحـث لمفهـوم الهبـة، فلغــةً هـى العطيـة الخاليـة مـن العـواض والأغراض، أما اصطلاحاً فهى عقد تمليك يملك فيه الواهب فى حال حياته الموهوب له الهبة بدون عوض، والهبة عقد تبرع خال من أى عوض، وقد تعرض البحث كذلك لتعريف الهبة فى القوانين الوضعية؛ ثم تعرض لماهية الرجوع فى الهبة، فلغة يعنى رد وعدل وترك الشئ، أمسا اصطلاحاً فهناك معنى اصيل وهو رفع حكم العقد، وإعادته إلى ما كان عليه، ومعنى تبعى وهو ما يترتب على رفع حكم العقد من أثر، ويتمثل برجوع المشترى فى الثمن، ورجوع البائع بـالمبيع مـثلا، ثم تتـاول المبحث الثالث الطبيعـة القانونيـة للرجوع فـى الهبـة، حيـث قسمناه الى عدة مطالب، حيـث تــاول المطلب الأول مدى امكانيـة اعتبار الرجوع عن الهبة إقالة لها، أمـا المطلب الثانى فكان عن مدى امكانية اعتبار الرجوع عن الهبة إلغاءً لها، أما المطلب الثالث فكان عن امكانيـة اعتبار الرجوع عن الهبـة رداً لها، وأخيراً كان المطلب الرابع عن مدى إهى امكانية اعتبار الرجوع عن الهبة فسخاً لها، وانتهينا الى ان الهبة يتفق مع البعض من رد تلك الانظمـة، ولكنه يختلف عنهم ويتفرد عنهم، امـا المبحث الرابع فكان عن حكم الرجوع فى عقد الهبة سواء فى الفقه الاسلامى او القانون الوضعى، حيث قسمناه الى مطلبين، الاول كان عن مشروعية الرجوع فى الهبة فى الفقه الاسـلامى، حيث فرق الفقهاء فى هذا الثأن بين حالة الرجوع قبل القبض، وفى ذلك الفرض انقسم الفقهاء الى رأيين، الاول يرى أن الهبة تجوز ، أما الرأى الثانى فيرى أنها لا تجوز ، وانتهينا هنا إلى أننا نميل الى الرأى الثانى، لوقوة ووجاهة الادلة والاسانيد التى ساقها، وعليه 
فان الاصل العام فى هذا الموضوع هو عدم قابلية الرجوع فى عقد الهبـة إلا فى سى استثناءات ضيقة، ألا وهى رجوع الاهبو هذين.

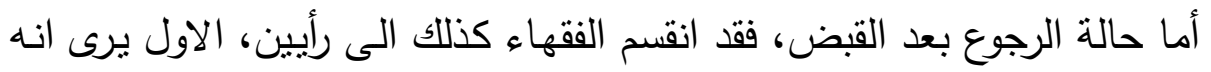

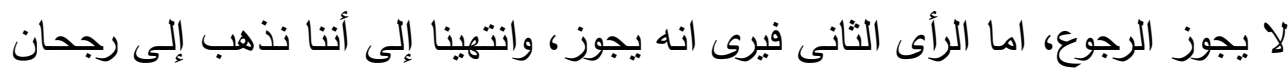

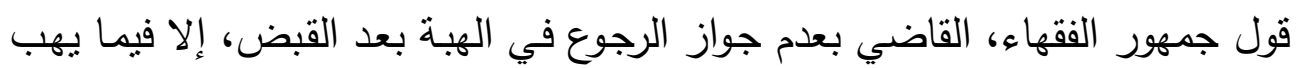
الوالد لولده؛ لأن الهبة في النهاية لا تخرج عن كونها عقد.

اما المطلب الثانى فكان عن مشروعية الرجوع فى الهبة فى القوانين الوضعية،

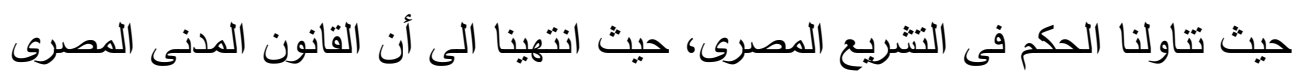

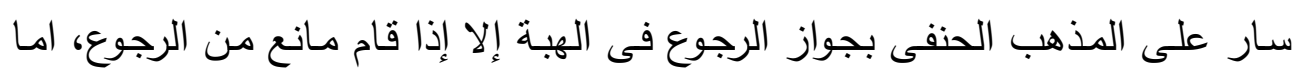

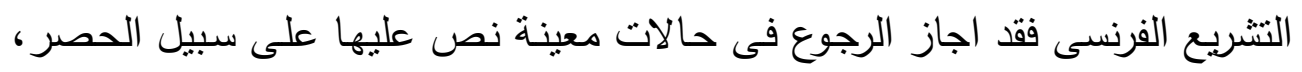

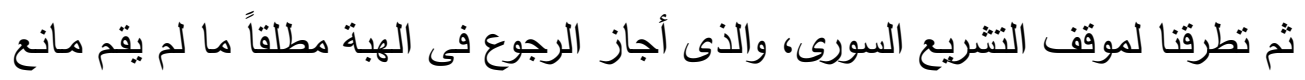

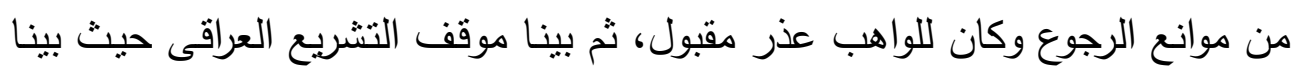

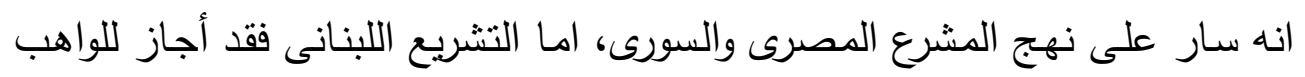

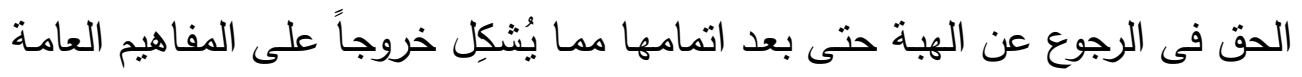

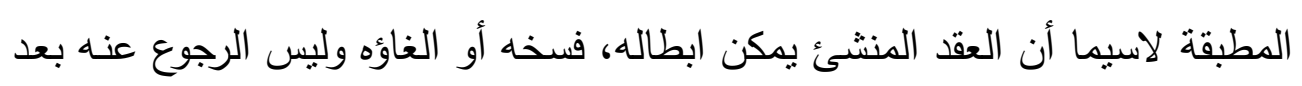

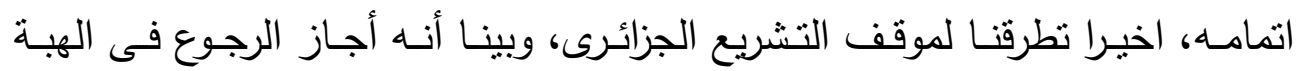

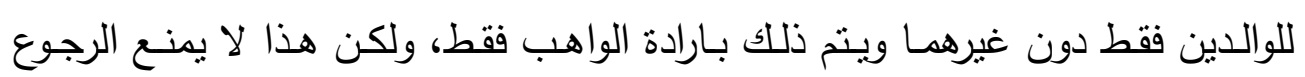
بالتراضى بين الواهب والموهوب له.

وأخيراً تتاول البحث آثار الرجوع فى الهبة، حيث تتاول آثار الرجوع فى الهبة

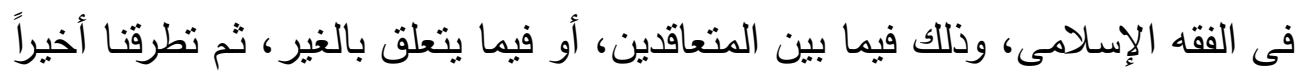

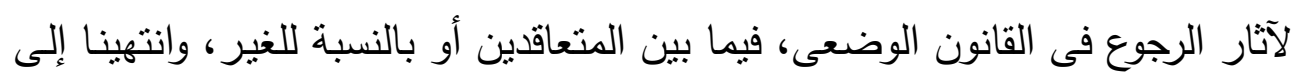

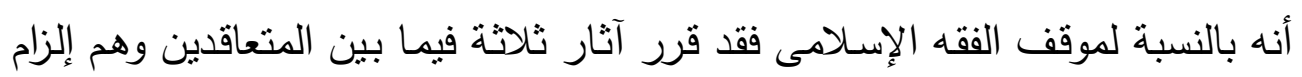

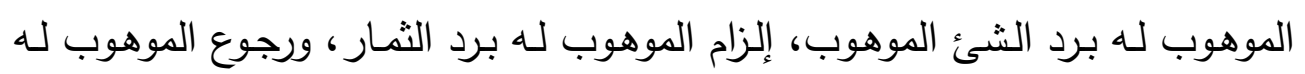


بالمصروفات على الواهب، أما فيما يتعلق بآثار الرجوع بالنسبة للغير فإن للموهوب له الرجوع على الواهب بالمصروفات التى صـرفها على الشئ الموهوب، وذللك على أساس الإثراء بـلا سبب، إذ أن الموهوب له قد صرف على الشئ الموهوب حتى زاد ذلك فى قيمته، والواهـب إذ يرجـع الشئ فى ذمته، فهو بـذلك يثرى على حساب الموهوب له المعتصر منه، أما بالنسبة للآثار بالنسبة للغير فإن الرجوع في الهبة في الفقه الإسـامي ليس لله أثر رجعي بالنسبة للغير حسن النية، والذّي تجب المحافظة على حقوقه، نزولا على المبادئ العامـة في الفقه الإسـامي ولا سيما قاعدة لا ضرر ولا ضرار -

أمسا بالنسبة لآثار الرجوع فى القوانين الوضعية، فقد تتاولنا القانون المصرى، العراقى، الجزائرى، حيث تتاولنا الآثار والالنزامـات المترتبـة والحقوق سواء فيمـا بين

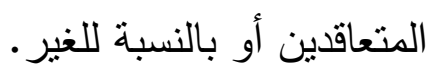




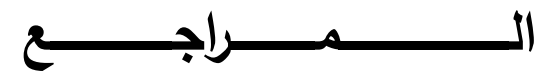

د. .اسماعيل عبدالنبى عبدالجواد، انقضاء العقد بالالغاء والرجوع فى القانون المدنى دراسة

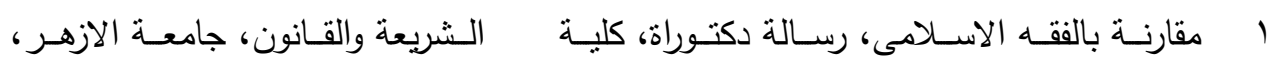
. $1914 / 8) \leq \cdot r$

د. محمد تقنية، الهبة فى قانون الاسرة والقانون المقارن، رسالة دكتوراة، معهد الحقوق والعلوم

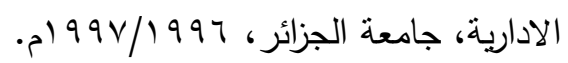

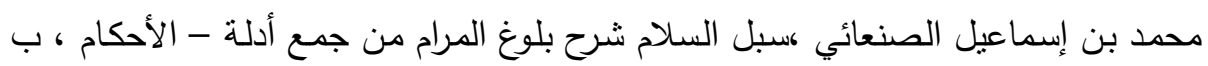
الطبعة الأولى ، 991 19 ، بيروت لبنان ، دار إحباء التراث العربي.

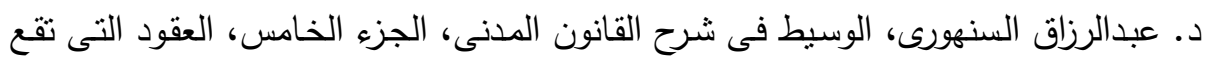
على الملكية.

د. نادر عبد العزيز شافي، عقد الهبة في القانون اللبناني والمقارن، الجزء الأول، المؤسسة الحديثة للكتاب،طرابلس، r ب. . rم، دراسة فقهية. د.غنى مواس، إثكاليات الهبة في القانون اللبناني، كلية الحقوق والعلوم السياسية والاداريةالفرع الثالث، الجامعة اللبنانية. ابن مفلح، أبو عبدالله محمد المقدس، ت:(r آهـ). الفروع، الطبعة الأولى، تحقيق: أبو

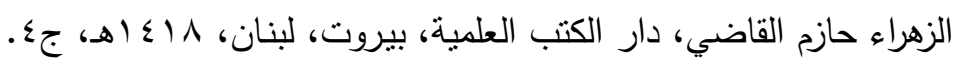

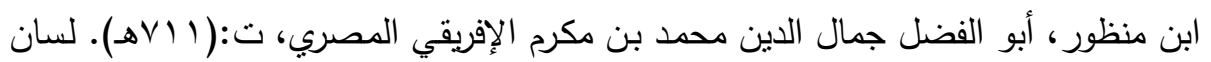
العرب، دار صادر ، بيروت.

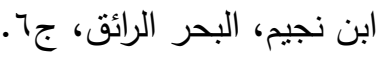

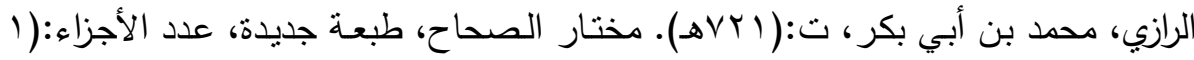

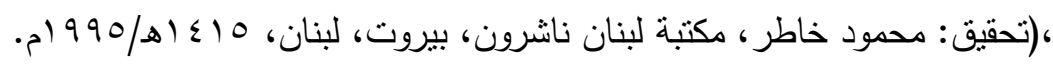

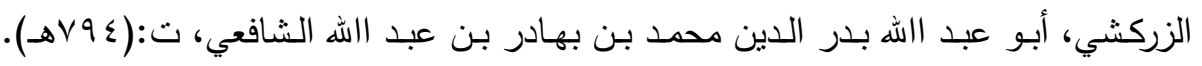

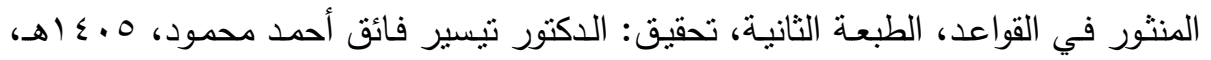

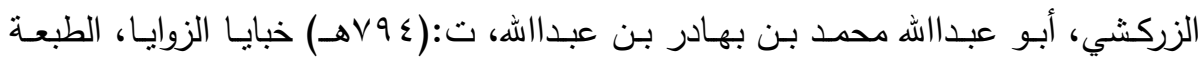

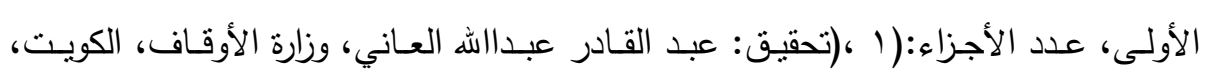




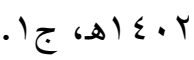

السيد سـابق، فقه السنة، الجزء الثالث، الطبعـة الثانية، دار العلم للملايين، بيروت، لبنان، .0199 .

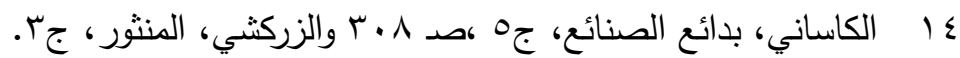

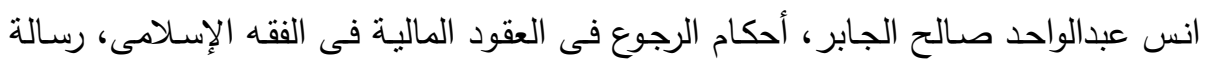

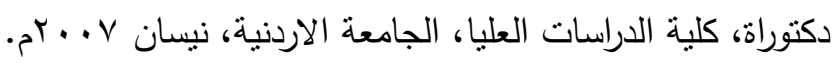

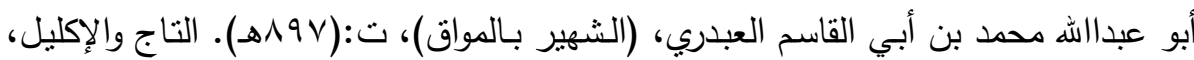

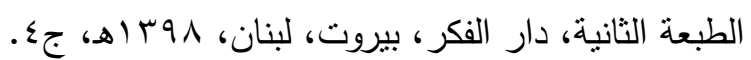

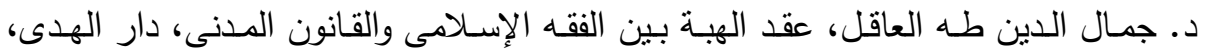
مصر ، 971

د. جمال محمد عيسى الاثقر ، احكام الدين في الفقه الاسلامى، مكتبة الايمان بالمنصورية، $.9 r \cdot \cdot V$

د. حسن محمد بودى، موانع الرجوع في الهبة "في الفقه الإسـامي والقانون الوضعي"، دار

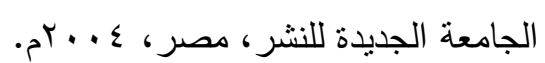

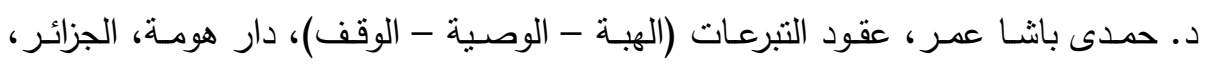

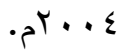

د. عبد الرزاق أحمد السنهوري، الوسيط في شرح القانون المدني ( ه ) العقود التي تقع على

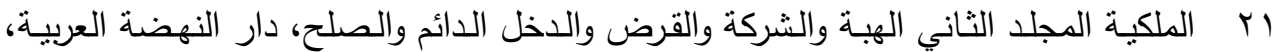

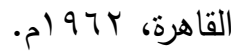
د. قصى سلمان هلال، الرجوع فى الهبة فى التشريع العراقى : دراسـة مقارنة، قسم القانون -

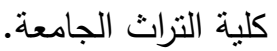

د. مـازن مـصباح صـباح، الهبـة فـى مـرض المـوت: دراسـة فقهيـة مقارنـة، مجلـة الجامعـة

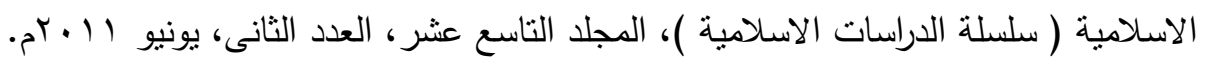
د. دحمد بن احمد تقية، دراسة عن الهبة فى قانون الاسرة الجزائري، الديوان الوطنى للانفال

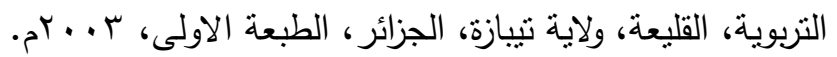
د. محمد بن احمد تقية، دراسة عن الهبة فى قانون الأسرة الجزائرى مقارنا بأحكام الشريعة

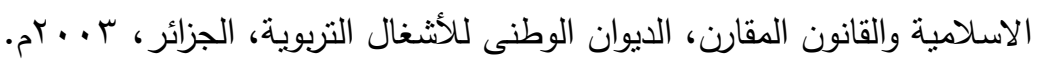
د. دحمد كامل مرسى، شرح القانون المدنى: العقود المسماة، الطبعة الثانية. 
د. محمد كمال حمدى، المواريث والهبة والوصية، دار المطبوعات الجامعية، الاسكندرية،

د. محيي الدين اسماعيل، علم الدين أصول القانون المدني، الجزء الثاني ، العقود المسماة ، الطبعة غير مذكورة ، مطبعة الساحل ، الرباط. rA

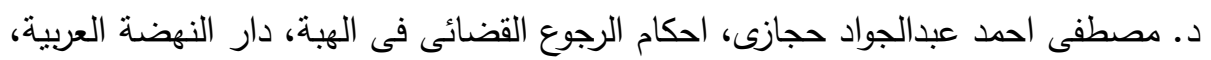

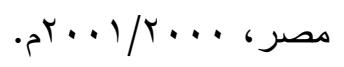

د. نجيمى جمال، قانون الاسرة الجزائرى "دليل القاضى والمحامى"، مادة بمادة على ضوء

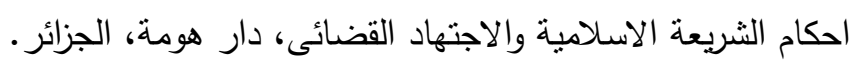

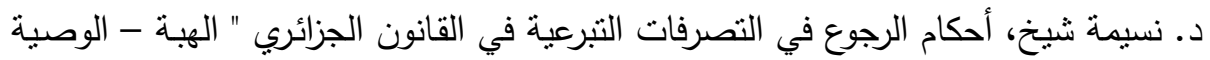
ا T - الوقف : دراسة مقارنة مدعمة بالأحكام الفقهية والاجتهاد القضائي "، الطبعة الثانية، دار

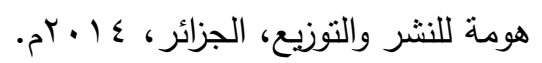

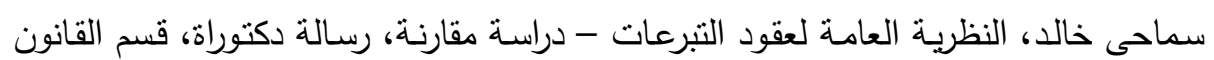

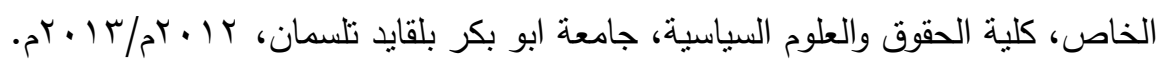
rr صحراوى العربى، ادارة امـلاك الدولـة فى الجزائر ، رسـالة ماجستير ، كليـة الحقوق والعلوم

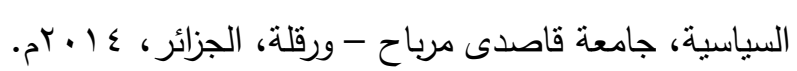
r

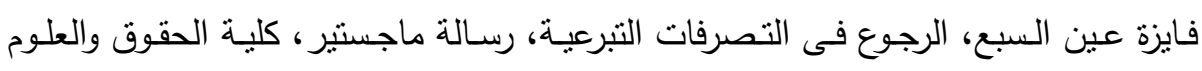

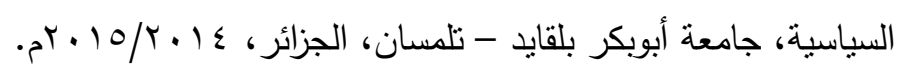
rร

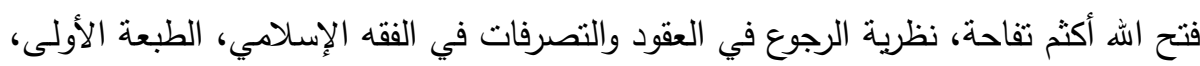

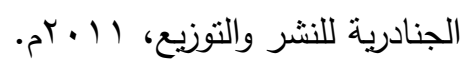

فريدة هـلال، الهبـة في ضـوء القانون والقضاء الجزائرى، رسـالة ماجستير ، كليـة الحقوق،

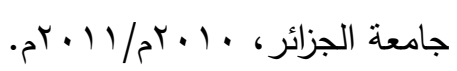
ru لكفوي، أبـو البقاء بـن موسى الحسيني، الكليـات (معجم المصطلحات والفروق اللغويـة)،

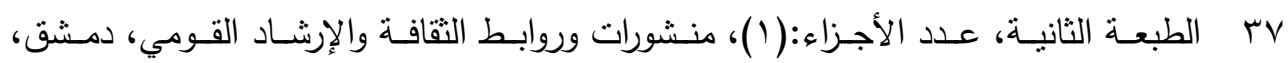
- $) 91 \mathrm{r}$ ليديـة كبيش، مـريم أيـت أوديـع، الرجهوع عـن الهبـة بـين الفقهه الاسـلامى والقـانون، رسـالة

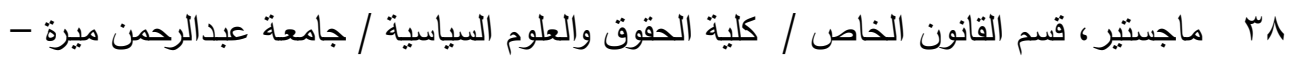

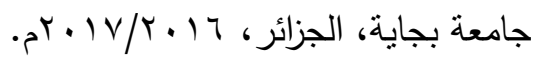

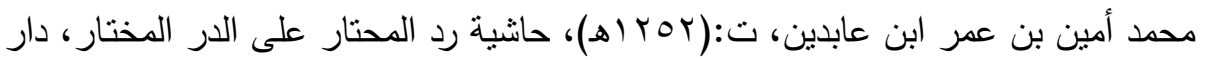




$$
\text { الفكر ، بيروت، لبنان، ابك (هـ، ج^. }
$$

محمد بن على الثوكانى، السيل الجرار المتدفق على حدائق الازهار، دار ابن حزم، الطبعة

$$
\text { الاولى، ع - . بام. }
$$

موسـوعة أحاديـث أحكام المعـاملات الماليـة: موسـوعة تصنيفية منهجيـة فقهيـة لأحاديـث

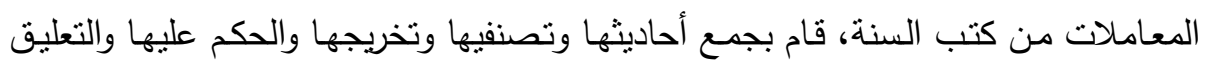
عليها، دار الكوثر للنشر والتوزيع، الرياض، المملكة العربية السعودية، الطبعة الأولى، محرم

$$
\text { الاس اهـ، مركز دراسات السنة النبوية - عمان - الأردن. }
$$

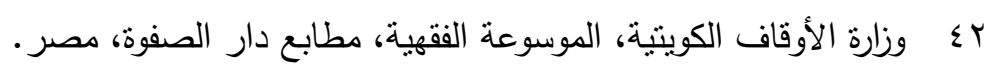

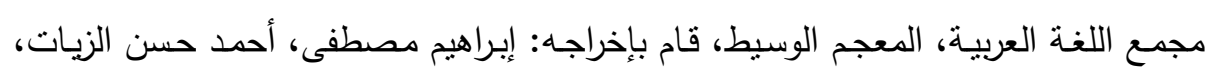
حامد عبد القادر ، محمد علي النجار، مطبعة دار الدعوة.

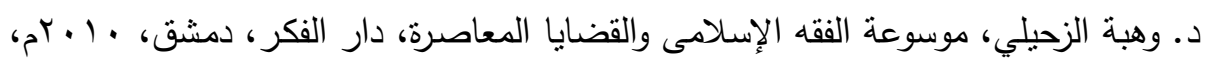
الجزء الخامس.

د. عبدالرحمن الجزيرى، الفقه على المذاهب الاربعـة، الجزء الثالث، مكتبـة الثقافة الدينيـة،

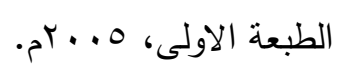

